Carlos Henrique Lopes de Souza

\title{
Uma análise da expansão de capacidade do corredor BRT TransOeste pelo método das \\ Opções Reais
}

Dissertação de Mestrado

Dissertação apresentada como requisito parcial para obtenção do grau de Mestre pelo Programa de PósGraduação em Administração de Empresas do Departamento de Administração da PUC-Rio.

Orientador: Prof. Luiz Eduardo Teixeira Brandão 
Carlos Henrique Lopes de Souza

\title{
Uma análise da expansão de capacidade do corredor BRT TransOeste pelo método das \\ Opções Reais
}

Dissertação apresentada como requisito parcial para obtenção do grau de Mestre pelo Programa de PósGraduação em Administração de Empresas da PUCRio.

Aprovada pela Comissão Examinadora abaixo.

\author{
Prof. Luiz Eduardo Teixeira Brandão \\ Orientador \\ Departamento de Administração - PUC-Rio \\ Prof. Carlos de Lamare Bastian-Pinto \\ Departamento de Administração - PUC-Rio \\ Prof. Marcus Vinicius Quintella Cury \\ Fundação Getúlio Vargas - FGV
}

Rio de Janeiro, 16 de março de 2020. 
Todos os direitos reservados. É proibida a reprodução total ou parcial do trabalho sem autorização da universidade, do autor e do orientador.

\section{Carlos Henrique Lopes de Souza}

Graduado em Administração na Pontifícia Universidade Católica do Rio de Janeiro (2016).

Ficha Catalográfica

Lopes de Souza, Carlos Henrique

Uma análise da expansão da capacidade do corredor BRT TransOeste pelo método das Opções Reais/ Carlos

Henrique Lopes de Souza; orientador: Luiz Eduardo Teixeira Brandão. - Rio de Janeiro PUC, Departamento de Administração, 2020.

109.f: il. color.; $30 \mathrm{~cm}$

1. Dissertação (mestrado) - Pontifícia Universidade Católica do Rio de Janeiro, Departamento de Administração.

Inclui referências bibliográficas

1. Administração - Teses. 2. Opções Reais. 3. Modelo binomial. 4. Expansão. 5. Adiamento, 4. Demanda de pico. 5. BRT. I. Brandão, Luiz Eduardo Teixeira (Luiz Brandão). II. Pontifícia Universidade Católica do Rio de Janeiro. Departamento de Administração. III. Título.

CDD: A incluir 


\section{Agradecimentos}

Ao Senhor da minha vida e da minha história, Jesus Cristo, e à minha Mãe Rainha, Nossa Senhora, pela providência divina desde o início desta jornada.

Ao meu professor e orientador, Luiz Eduardo Brandão, pelo estímulo, aconselhamento, respeito e cordialidade com que fui tratado ao longo do da realização deste trabalho. O senhor é uma referência inspiradora para a minha profissão. Meu muito obrigado.

À PUC-Rio, à CNPq e à CAPES, pelos auxílios concedidos, sem os quais este trabalho não poderia ter sido realizado.

Ao meu colega de estudo, Rodrigo Santana, ao André Ormond, e ao Marco Freire, que possibilitaram o meu acesso aos dados necessários para a realização deste trabalho. Muito obrigado.

Aos professores e colegas com os quais convivi ao longo deste período, pelos bons momentos vividos e desafios superados.

À minha família, minha base e meu porto seguro, sem a qual eu jamais teria chegado até aqui.

De forma singela, à minha namorada, noiva, e futura esposa, Raquel Gonçalves. Suas orações me deram forças para seguir adiante. Eu te amo.

"O presente trabalho foi realizado com apoio da Coordenação de Aperfeiçoamento de Pessoal de Nível Superior - Brasil (CAPES) - Código de Financiamento 001" 


\section{Resumo}

Lopes de Souza, Carlos Henrique; Brandão, Luiz Eduardo Teixeira (Orientador). Uma análise da opção de expansão da capacidade do corredor BRT TransOeste pelo método das Opções Reais.

Rio de Janeiro, 2020, 109p. Dissertação de Mestrado Departamento de Administração, Pontifícia Universidade Católica do Rio de Janeiro.

Projetos de infraestrutura de transporte de massa desempenham um importante papel no planejamento urbano das zonas urbanas, podendo influenciar na geração de crescimento econômico e o aumento do bemestar social. Entre as variadas opções de modos de transporte de massas existentes está o BRT, caracterizado por ser um sistema que requer um curto tempo de implementação, baixo custo de construção, e possui velocidade operacional e nível de capacidade médios. Em comparação com outros modos de transporte de maior capacidade, como trens e metrôs, o BRT é uma opção viável e atraente ao modo de transporte, dado o ritmo crescente de sua implementação em várias cidades ao redor do mundo nos últimos anos. Neste estudo, foi feita uma análise do corredor BRT TransOeste da cidade do Rio de Janeiro, sob a ótica da Teoria das Opções Reais, com o objetivo de avaliar o valor da opção de expandir a capacidade de passageiros transportados atualmente naquele corredor. Os resultados do estudo sugerem que a incorporação de estratégias interativas das Opções Reais, relativas às decisões de expansão da capacidade máxima de passageiros do corredor e de adiamento do exercício desta decisão, contribuíram para aumentar o valor esperado do projeto em $30,63 \%$. Além disso, foi observado que o aporte de recursos realizados pelo poder concedente contribuiu para aumentar o valor da opção real de expansão.

\section{Palavras-chave}

Opções Reais; modelo binomial; expansão; adiamento; demanda de pico; BRT. 


\section{Abstract}

Lopes de Souza, Carlos Henrique; Brandão, Luiz Eduardo Teixeira (Advisor). An analysis of the option to expand the capacity of the BRT TransOeste corridor via the Real Options method. Rio de Janeiro, 2020, 109p. Dissertação de Mestrado - Departamento de Administração, Pontifícia Universidade Católica do Rio de Janeiro.

Mass transportation infrastructure projects play an important role in the process of development of urban areas, leading to economic growth and increase of social welfare. Among the various existing types of transit modes is the BRT, which is characterized by being a system that requires a short time of implementation and a low cost of construction, operating in an medium level of operational speed and capacity. In comparison with other transit modes of higher capacity such as trains and subways, the BRT has shown to be a feasible and attractive alternative, as noted by the increasing pace of its implementation in many cities throughout the world in recent years. In this study, an analysis was made of the BRT TransOeste corridor in the city of Rio de Janeiro from the perspective of the Theory of Real Options in order to assess the value of the option of expanding passenger capacity in that corridor. The results suggest that the incorporation of interactive strategies of Real Options related to the decisions of expanding the maximum capacity of passengers and deferring this decision contributed to increase the expected value of the project by $30.63 \%$. In addition, the contribution of the granting authority led to an increase in value of the real option.

\section{Keywords}

Real Options; binomial model; expansion; deferral; peak demand; BRT. 


\section{Sumário}

1 . Introdução 16

1.1. Problema de pesquisa 17

1.2. Importância do estudo 17

1.3. Questões de pesquisa 18

1.4. Objetivos gerais e específicos 18

$\begin{array}{ll}\text { 1.5. Organização do trabalho } & 19\end{array}$

2 . Revisão de literatura $\quad 20$

2.1. Teoria de Opções Reais 20

2.1.1. Processos estocásticos 22

2.1.2. Modelos de precificação de Opções 24

2.2. Opções Reais em projetos de Infraestrutura 27

2.2.1. Aspectos teóricos 27

2.2.2. Evidências empíricas 29

3 . Bus Rapid Transit (BRT) 34

3.1. Definição 34

3.2. Panorama histórico do BRT ao redor do mundo 35

3.3. O sistema BRT no Rio de Janeiro 36

3.3.1. BRT Rio e os grandes eventos 36

3.3.2. Características do BRT Rio de Janeiro 37

3.4. O contexto do BRT do Rio pós-Olimpíadas 39

3.5. Série histórica da frota diária do corredor TransOeste 41

4 . Metodologia 43

4.1. Estrutura da pesquisa 43

4.2. Métodos de avaliação dos resultados do estudo 45

5 . Modelo de expansão da capacidade do corredor BRT TransOeste46

5.1. Série histórica de passageiros 46 
5.1.1. Cálculo da volatilidade 47

5.1.2. Proporção de passageiros pagantes e não pagantes 48

5.1.3. Pico diário médio de passageiros por dia útil 49

5.2. Estimativa da frota diária 50

5.2.1. Estudo de oferta de frota diária 51

5.2.2. Fator de carregamento de passageiros (load factor) 52

5.3. Estimativa da quilometragem percorrida diária 53

5.4. Fluxo de caixa do projeto 57

5.4.1. Cálculo das receitas 58

5.4.2. Custos operacionais 62

5.4.3. Depreciação 70

5.4.4. Tributos incidentes sobre o Resultado 71

5.4.5. Resultado operacional líquido 72

5.4.6. Investimento $\quad 72$

5.5. Análise do projeto pelo método das Opções Reais 76

5.5.1. Avaliação do projeto pelo método do FCD 77

$\begin{array}{ll}\text { 5.5.2. Análise neutra ao risco } & 77\end{array}$

5.6. Modelo de árvores de decisão binomial do BRT TransOeste 78

5.6.1. Parâmetros de incerteza do projeto 79

5.6.2. Parâmetros de flexibilidade do projeto 83

6. Análise dos resultados do método de Opções Reais 91

6.1. Valor do projeto expandido e da opção 91

6.2. Probabilidades da árvore de decisão por ano 92

$\begin{array}{ll}\text { 6.3. Análise de sensibilidade } & 94\end{array}$

6.4. Análise do projeto com a inclusão de incentivos governamentais 95

6.4.1. Despesas de capital para aquisição de ativos 95

6.4.2. Mitigação de risco de evasão de passageiros 98

$\begin{array}{ll}7 . \text { Conclusões } & 100\end{array}$

8 . Referências bibliográficas 103 
9. Anexos

9.1. Fluxo de caixa do projeto pelo método do FCD 106

9.2. Fluxo de caixa do projeto pela abordagem neutra ao risco 107

9.3. Demanda diária média de passageiros transportados por estação 108

9.4. Linhas de ônibus por estação do corredor BRT TransOeste 109 


\section{Lista de figuras}

Figura 1: Árvore de decisão binomial para três períodos $\quad 26$

Figura 2: Corredores do sistema BRT Rio 38

Figura 3: Veículos do eixo troncal e veículos alimentadores do BRT Rio 38

Figura 4: Comparativo da frota diária $x$ demanda de pico diária por dia útil

Figura 5: Metodologia de pesquisa Fonte: o autor

Figura 6 Passageiros transportados no BRT TransOeste em dias úteis 46

Figura 7: Demanda diária média de passageiros em dias úteis por trimestre

$\begin{array}{ll}\text { Figura 8: Demanda diária de passageiros por dia útil por hora } & 47 \\ & 49\end{array}$

Figura 9 Frota diária $x$ capacidade máxima por dia útil 51

Figura 10: Frota diária média por hora por dia útil 53

Figura 11: Quilometragem média percorrida por dia útil no corredor BRT TransOeste

Figura 12: Quilometragem média percorrida por hora x Frota disponível por hora

Figura 13: Quilometragem média percorrida por hora x frota média por hora em dias úteis

Figura 14: Demanda de pico $\times$ Demanda total diária por dia útil 81

Figura 15: Diagrama do modelo binomial 84

Figura 16: Opção de adiar a expansão em dois períodos 87

Figura 17: Opção de expandir, após opção de adiamento 89

Figura 18: Valor esperado do projeto expandido pelo método das Opções Reais

Figura 19: Sumário de decisões de expansão e adiamento pela abordagem neutra ao risco

Figura 20: Análise de sensibilidade do valor esperado do projeto à taxa de volatilidade 94

Figura 21: Valor esperado do projeto x participação \% em gastos de capital para a expansão do sistema 
Figura 22: Sumário de probabilidades da participação do poder concedente (25\%)

Figura 23: Sumário de probabilidades da participação do poder concedente (50\%)

Figura 24: Valor esperado do projeto $\mathrm{x}$ índice de evasão de passageiros 


\section{Lista de tabelas}

Tabela 1: Parâmetros do modelo binomial de Cox, Ross e Rubinstein 26

Tabela 2: Estudos de Opções Reais aplicados à projetos de infraestrutura

Tabela 3 Categorias de passageiros por dia útil 48

Tabela 4: Demanda diária de passageiros por dia útil por hora 50

Tabela 5: Fator de carregamento do horário de pico 52

Tabela 6: Quilometragem média diária percorrida por dia útil Fonte: o autor 56

Tabela 7: Fluxo de caixa do modelo 58

Tabela 8: Dados de passageiros transportados no Consórcio Operacional do BRT entre janeiro e agosto de $2019 \quad 60$

Tabela 9: Tributos incidentes sobre a receita bruta 62

Tabela 10: Pessoal de operações 63

Tabela 11: Categorias de estações do corredor BRT TransOeste 64

Tabela 12: Dados para o cálculo do custo de rodagem 68

Tabela 13: Tributos incidentes sobre o resultado 71

Tabela 14: Demanda máxima por estação em dias úteis 73

Tabela 15: Capacidade máxima estimada pelo método de Hidalgo et al (2013)

Tabela 16: Parâmetros do modelo binomial 


\section{Lista de equações}

Equação 1: Valor do projeto com opções 22

Equação 2: Processo de Wiener 23

Equação 3: Movimento browniano com drift 23

Equação 4: Movimento geométrico browniano 23

Equação 5: Movimento de reversão à média 24

Equação 6: Estimativa do tamanho da frota por período 50

Equação 7: Quilometragem total percorrida por dia útil 56

Equação 8: Demanda de usuários pagantes $\quad 59$

Equação 9: Demanda de usuários pagantes com evasão de passageiros

60

Equação 10: Cálculo do total de passageiros pagantes 60

Equação 11: Cálculo da receita tarifária 61

Equação 12: Cálculo da folha de pagamento do pessoal de operação 63

Equação 13: Cálculo do custo total com pessoal de operação 64

Equação 14: Cálculo do custo total com o pessoal de operação e manutenção 65

Equação 15: Cálculo do custo com consumo de combustível 66

Equação 16: Cálculo do custo com consumo de ARLA 66

Equação 17: Cálculo do custo de consumo com lubrificantes 67

Equação 18: Cálculo do custo com peças e acessórios 67

Equação 19: Quilometragem anual média percorrida 68

Equação 20: Cálculo do custo com rodagem 68

Equação 21: Cálculo do custo com garagens e instalações 69

Equação 22: Cálculo do custo total com insumos 69

Equação 23: Cálculo do custo com IPVA e DPVAT 69

Equação 24: Cálculo das despesas administrativas 70

Equação 25: Cálculo da despesa de depreciação 71

Equação 26: Cálculo do resultado operacional líquido 72

Equação 27: Cálculo da capacidade máxima de passageiros por estação

Equação 28: Cálculo do fluxo de caixa do projeto 76 
Equação 29: Fluxo de caixa do projeto como função da demanda de pico

Equação 30: Valor esperado do fluxo de caixa do projeto neutro ao risco 78

Equação 31: Cálculo da demanda diária estocástica 81

Equação 32: Cálculo da frota diária estocástica 82

Equação 33: Cálculo da quilometragem percorrida estocástica 83

Equação 34: Cálculo do investimento da opção de expansão da demanda de pico

85

Equação 35: Fluxos de caixa da opção de adiar a expansão da demanda de pico

86

Equação 36: Cálculo da receita de revenda da frota excedente da opção de adiamento

88

Equação 37: Cálculo do investimento em redimensionamento da frota da opção de expansão, seguida da opção de adiamento 
"É preciso trabalhar como se a gente não fosse morrer nunca, e viver como se a gente devesse morrer todos os dias." - São João Bosco 


\section{Introdução}

Em 2012, a cidade do Rio de Janeiro ganhou uma nova modalidade de serviço de transporte público: o Bus Rapid Transit (BRT), que consiste em um sistema de corredores exclusivos de ônibus articulados. O sistema BRT do Rio de Janeiro foi originalmente concebido para atender a demanda da cidade para os eventos da Copa do Mundo de 2014 e das Olimpíadas de 2016, a um custo total de $R \$ 5,5$ bilhões (William, Alexandre, \& Balassiano, 2012).

A implantação do BRT trouxe avanços significativos na questão da mobilidade urbana da cidade do Rio de Janeiro. Foi notado inicialmente um aumento na eficiência do deslocamento e uma diminuição do tempo de viagem dos usuários do novo sistema. No entanto, com o passar do tempo, começou a surgir uma série de problemas que passaram a prejudicar seriamente o desempenho operacional do sistema.

A escalada crescente desta situação culminou com a necessidade de uma intervenção temporária do poder concedente, a fim de averiguar a causa destes problemas e propor soluções. Um dos pontos críticos abordados ao longo do período de intervenção diz respeito à existência de um descompasso entre a demanda de passageiros inicialmente projetada para esse sistema e a demanda efetivamente realizada ao longo dos anos, dado que o sistema alcançou um nível de saturação em um prazo muito curto. Dos três corredores que integram o sistema BRT do Rio de Janeiro (TransOeste, TransCarioca e TransOlímpica), o corredor TransOeste foi o que apresentou os índices mais críticos de desempenho operacional, com episódios constantes de superlotação nos horários de pico, decorrentes da disponibilidade insuficiente de veículos para atender a grande demanda de passageiros do corredor, do subdimensionamento do tamanho das estações, e da quebra constante de veículos, entre outros problemas.

É conhecida a importância do papel que grandes projetos de infraestrutura de transporte de massa desempenham na questão do planejamento urbano das grandes cidades, seus diferentes níveis de complexidade e a necessidade de se aliar as políticas públicas com o aumento do bem-estar social para os cidadãos. Tendo em vista isso e, considerando as questões apresentadas acerca da 
situação na qual o corredor BRT TransOeste se encontra, este estudo foi desenvolvido com o objetivo de analisar a opção de expandir a capacidade operacional do corredor TransOeste do sistema BRT da cidade do Rio de Janeiro, pelo método das Opções Reais.

\subsection{Problema de pesquisa}

Em termos de conveniência operacional, o BRT se apresenta como uma solução criativa de transporte de baixo custo e de rápida implementação. Entre as suas principais características estão a operação em vias segregadas, uso de bilhetagem eletrônica, dispositivos de rastreamento operacional, embarque e desembarque eficiente de passageiros nas estações planejadas para o sistema, entre outros (Hensher \& Golob, 2008).

Para um alcance operacional eficaz, o sistema BRT requer uma combinação de velocidades operacionais elevadas com serviços frequentes e constantes, oferecendo um atendimento de qualidade, com exatidão na frequência dos ônibus, conforto e segurança para os passageiros (Ministério das Cidades, 2008).

Tendo em vista as questões apresentadas acerca do sistema BRT, cabem as seguintes perguntas:

- Existe viabilidade em realizar a expansão a capacidade do corredor BRT TransOeste, por meio da readequação do sistema atual, ou é preferível manter o sistema com o mesmo nível de capacidade atual? Caso seja viável, em que momento é mais esta expansão do sistema deve ser feita?

- Como a participação do poder concedente com o aporte de recursos pode contribuir para aumentar a viabilidade da opção de expandir a capacidade operacional do corredor BRT TransOeste? Qual o impacto da inclusão desses incentivos governamentais no valor da opção de expansão da capacidade atual do corredor?

\subsection{Importância do estudo}

O estudo apresenta uma proposta de interesse e relevância para políticas públicas da cidade do Rio de Janeiro, no tocante a estratégias de planejamento urbano de médio e longo prazo.

Ademais, este estudo apresenta uma contribuição para a literatura de Opções Reais, no sentido de incorporar técnicas de avaliação de projetos com alto nível de incerteza, em um contexto empírico do setor de transporte público. 


\subsection{Questões de pesquisa}

Tendo em vista o contexto apresentado até o momento sobre o sistema BRT do Rio de Janeiro, são apresentadas algumas questões para nortear o presente estudo:

- Qual o valor da opção de expansão da capacidade de passageiros transportada atual do sistema BRT TransOeste?

- O quanto a participação do poder concedente com o aporte de incentivos influencia no aumento do valor da opção real da expansão da capacidade do corredor?

- É viável expandir a capacidade do BRT TransOeste? Se for, em que momento ela deve ser exercida?

\subsection{Objetivos gerais e específicos}

O objetivo geral deste estudo é propor uma análise para avaliar o valor da opção de expansão da capacidade de passageiros transportados no corredor BRT TransOeste. Para isso, o projeto foi modelado como um contrato de concessão em regime de parceria público-privada, assumindo também a incorporação de incentivos governamentais baseados em concessões dessa natureza.

Entre os objetivos específicos do estudo estão:

- Analisar a série histórica da demanda de passageiros do sistema BRT TransOeste, de modo a definir a volatilidade da incerteza do modelo;

- Analisar o comportamento da demanda diária média de passageiros em dias úteis, em cada hora do dia, no corredor BRT TransOeste, e nas estações que o compõem, e identificar o tamanho da demanda média de passageiros no horário de pico, de forma a definir o tamanho da frota mínima para atender essa demanda.

- Definir os parâmetros e o processo de difusão mais adequado para modelar a incerteza da demanda estocástica projetada no modelo;

- Descrever adequadamente as premissas da opção avaliada no modelo, analisando seus custos e despesas, e montar os fluxos de caixa projetados;

- Comparar o valor da opção de expansão da capacidade das propostas e do sistema BRT atual, com e sem a inclusão dos incentivos governamentais; 
- Definir se é viável exercer a opção de expandir a capacidade de passageiros e, se for, qual o momento ideal para exercer a mesma.

\subsection{Organização do trabalho}

A presente dissertação está dividida em sete capítulos. Após este capítulo introdutório, foi feita uma revisão de literatura da Teoria das Opções Reais, além de uma breve exemplificação de alguns trabalhos desenvolvidos na literatura de Opções Reais, aplicados a projetos de Infraestrutura. O capítulo 3 apresenta uma contextualização do sistema BRT, citando alguns exemplos desse sistema em algumas cidades no mundo e com enfoque no BRT da cidade do Rio de Janeiro, o contexto histórico de sua implantação da cidade, além de algumas observações e recomendações sobre o desempenho operacional do mesmo, tomando como base o Relatório de Intervenção do BRT Rio, realizado entre os meses de janeiro a julho de 2019. No capítulo 4, é apresentada a metodologia onde são discriminados os passos necessários para a realização do estudo. No capítulo 5 , é detalhada a construção dos parâmetros e premissas do modelo proposto, desde a montagem do fluxo de caixa do projeto do BRT TransOeste, até o modelo de Opções Reais utilizado para calcular o valor da opção de expansão da capacidade do corredor BRT TransOeste. No capítulo 6, é feita a análise e a discussão dos resultados, e, em seguida, o capítulo 7 finaliza o estudo com as conclusões e recomendações. 


\section{Revisão de literatura}

\subsection{Teoria de Opções Reais}

A teoria das Opções Reais emergiu a partir do trabalho seminal de Black \& Scholes (1973), que elaboraram formulações teóricas para a avaliação de ativos financeiros - opções. Apenas uma década após o seu surgimento, a teoria das Opções Reais já era aplicada em muitos campos - recursos naturais, governança corporativa, pesquisa e desenvolvimento e estratégia corporativa.

Trigeorgis (1996) afirma que o uso do método tradicional do fluxo de caixa descontado (FCD) para avaliação de projetos de investimento não é capaz de capturar adequadamente a flexibilidade gerencial para adaptar e revisar decisões post-hoc em resposta a mudanças inesperadas no ambiente de mercado. As limitações do método tradicional do FCD tornam mais difícil uma determinação mais precisa da taxa de desconto de um projeto, quando considerada a inclusão das variáveis de incerteza subjacentes a ele.

Para o autor, a inclusão da abordagem das Opções Reais na avaliação de projetos de investimento tem a capacidade de conceituar e quantificar o valor de opções de estratégias interativas, o que possibilita a incorporação de elementos de flexibilidade e a alteração de estratégias previamente estabelecidas, aproveitando-se delas para capitalizar oportunidades ou mitigar riscos de perdas potenciais durante a vida útil de um projeto.

Segundo essa perspectiva, o valor de um projeto é tipicamente denominado com uma coleção de "opções reais", que estão entremeadas em oportunidades de investimento de capital, tendo como ativo subjacente da opção o valor bruto dos fluxos de caixa descontados esperados de determinado projeto. De acordo com o Trigeorgis (1996), algumas dessas opções podem ocorrer de forma natural, enquanto outras podem ser planejadas ou construídas a partir de um aporte financeiro inicial.

A flexibilidade está estreitamente ligada ao conceito das opções financeiras. Em opções financeiras, a posse de uma opção do tipo call dá ao seu dono o direito, mas não a obrigação, de adquirir um ativo específico (de valor atual $S$ ) por um preço pré-estabelecido (preço de exercício) antes ou até o período de vencimento 
da mesma. De forma similar, a opção de put confere o direito de realizar a venda de um ativo pelo preço de exercício da opção.

Trigeorgis (1996) lista alguns tipos de opções reais possíveis:

- Opção de adiamento: aguardar um tempo para se certificar que as condições de mercado justifiquem um determinado investimento;

- Opção de investimento em estágios: investimento realizado em etapas consecutivas, onde cada estágio é visto como uma opção do valor das opções subsequentes e avaliado como uma opção composta;

- Opcão de escala de produção: expansão, escalonamento, shutdown e/ou recomeço do projeto, com base nas condições de mercado;

- Opção de abandono: abandono das operações e liquidação dos bens de capital para mercados de segunda mão, caso as condições do mercado se deteriorem;

- Opção de switch: mudança do mix de outputs produzidos pela planta com base na mudança dos preços ou da demanda (flexibilidade de produto), ou produção dos mesmos outputs com base em mudanças no mix de inputs (flexibilidade de processo);

- Opção de crescimento: realização de investimentos pioneiros como prérequisito para a criação de futuras oportunidades de crescimento e de mercado.

Segundo Freitas \& Brandão (2009), ao se utilizar a abordagem das opções reais para avaliar ativos não-financeiros, deve-se seguir a seguinte premissa: a decisão de investir em uma oportunidade de negócio equivale ao exercício de uma opção financeira, como por exemplo, exercer o direito de compra (call) de uma ação por um preço pré-determinado $S$. Desse modo, os autores entendem uma opção real como um direito de se fazer um investimento, recebendo em troca os fluxos gerados por esse investimento e seus ativos, cujo valor se comporta de maneira estocástica ao longo do tempo.

Freitas \& Brandão (2009) traçam alguns paralelos entre os parâmetros característicos das opções financeiras e das opções reais, como por exemplo: o preço de exercício $S$ da opção financeira corresponde ao custo / do investimento; o preço de mercado do ativo equivale ao valor presente do projeto $V$; o prazo de expiração da opção $t$ corresponde à janela de tempo ao longo da qual uma organização pode adiar a decisão de investir sem perder a oportunidade do investimento; o desvio padrão $\sigma$ dos retornos do projeto corresponde à incerteza a respeito do valor futuro dos fluxos de caixa do projeto (o risco do projeto); e o 
valor do dinheiro no tempo é dado pelo fluxo descontado pela taxa livre de risco $r f$.

Ainda de acordo com os autores, o valor do projeto sem flexibilidades (também chamado estático), quando calculado pela metodologia de opções reais é o mesmo obtido pela metodologia do FCD. O valor da opção é obtido em função de dois fatores: a incerteza que é resolvida ao longo do tempo (ao menos parcialmente) e o valor do dinheiro no tempo. O valor da flexibilidade, chamado de prêmio da opção, é a diferença entre o VPL estimado do projeto pela metodologia do FCD (estático) e o VPL estimado aplicando-se a metodologia das opções reais. A Equação 1 esquematiza o valor do projeto com a inclusão da abordagem das Opções Reais:

$$
V P L_{\text {expandido }}=V P L_{\text {estático }}+\text { Valor das Opções }
$$

Freitas \& Brandão (2009) afirmam que, intuitivamente, o valor de um projeto com opções é dado pela avaliação do VPL dos fluxos de caixa esperados pela metodologia tradicional do FCD, somados à flexibilidade gerencial que cria valor para o projeto.

\subsubsection{Processos estocásticos}

Segundo Dixit \& Pindyck (1994), um processo estocástico é uma variável de incerteza que evolui ao longo do tempo de modo que ao menos uma fração da variação ocorra de maneira aleatória. Um processo estocástico pode se caracterizar de duas formas: como um processo em tempo discreto - onde as variáveis variam em unidades de tempo pré-definidas (por exemplo: dias, meses ou anos) -, ou como um processo em tempo contínuo, que pode admitir valores contínuos e variados ao longo do tempo (por exemplo: temperatura ou preços de ações).

\subsubsection{Processo de Wiener}

Para Dixit \& Pindyck (1994), o processo de Wiener - também chamado de movimento browniano - é um processo estocástico composto por três propriedades importantes: (1) é um processo markoviano, ou seja, a distribuição de probabilidade de todos os valores futuros do processo irão depender somente do valor atual e não serão afetados por valores ocorridos no passado ou por qualquer informação adicional atual; (2) possui incrementos independentes, ou seja, a distribuição de probabilidade das mudanças no processo em um intervalo 
de tempo é independente em relação a qualquer outro intervalo; e (3) as mudanças no processo em um intervalo finito de tempo são normalmente distribuídas, com variância de crescimento linear.

Um incremento de um processo de Wiener, $d z$, pode ser representado pela Equação 2:

$$
d z=\epsilon_{t} \sqrt{d t}
$$

Onde $\epsilon_{t}$ é uma variável aleatória com média zero e desvio-padrão 1 , e $d t$ é o intervalo de tempo do processo. O valor esperado de $d z$ é zero $(\varepsilon(d z)=0)$ e a variância esperada de $d z$ é igual a $d t(v[d z]=d t)$.

\subsubsection{Movimento Browniano com drift}

Segundo Dixit \& Pindyck (1994), o movimento browniano com drift é uma generalização de um processo de Wiener, que pode ser descrito da seguinte forma (Equação 3):

$$
d x=\alpha d t+\sigma d z
$$

Onde uma mudança na variável $x$ (representada por $d x$ ) possui um termo determinístico (representado por $d t$, que é o intervalo de tempo) e um termo estocástico (representado por $d z$, que é o incremento de um processo de Wiener). $\alpha$ é o parâmetro de drift (tendência de crescimento) e $\sigma$ é o parâmetro de variância, ambos constantes. Neste processo, no intervalo de tempo $d t$, a variável $d x$ é normalmente distribuída, com valor esperado $\alpha d t$ e variância $\sigma^{2} d t$.

\subsubsection{Movimento Geométrico Browniano (MGB)}

O Movimento Geométrico Browniano (MGB), segundo Dixit \& Pindyck (1994), é um caso especial do movimento browniano, representado pela Equação 4:

$$
d x=\alpha x d t+\sigma x d z
$$

Neste caso, as mudanças absolutas ocorridas em $x$ possuem distribuição lognormal. É o processo estocástico mais utilizado para modelagem de preços de valores mobiliários, taxas de juros, entre outras variáveis econômicas.

Brandão \& Saraiva (2008) sugerem a utilização do modelo MGB para a modelagem do comportamento futuro do fluxo de tráfego. O modelo implica que esses valores nunca poderão ser negativos e possuem volatilidade constante no tempo. 


\subsubsection{Movimento de reversão à média (MRM)}

Dixit \& Pindyck (1994) afirmam que, apesar de a utilização do processo browniano para a modelagem de alguns ativos ser plausível, como por exemplo, para medir a variação de preços especulativos de ações, existem situações nas quais não é possível aplicar este processo adequadamente. Segundo os autores, a variação ocorrida no preço de alguns ativos poderia estar atrelada a algum atributo ou característica de caráter perene, como por exemplo, os custos marginais de produção de longo prazo. Ou seja, a variação do preço de ativos de casos no quais esse pressuposto se aplicaria ocorreria em função de um atributo médio de longo prazo. Os autores citam como exemplo que se enquadraria nesta categoria de processo estocástico os preços de commodities (cobre ou óleo). Este tipo de processo estocástico é denominado como processo de reversão à média. $\mathrm{O}$ processo de reversão à média mais simples - também conhecido como o processo Ornstein-Uhlenbeck - é representado na forma da Equação 5:

$$
d x=\eta(\bar{x}-x) d t+\sigma d z
$$

Onde $\eta$ é a velocidade de reversão do ativo ao preço médio, e $\bar{x}$ é o valor médio para o qual $x$ tende a reverter no longo prazo.

\subsubsection{Modelos de precificação de Opções}

\subsubsection{Modelo de precificação de opções de Black \& Scholes (BSOPM)}

Black \& Scholes (1973) elaboraram uma formulação teórica para calcular o valor de opções financeiras. Segundo Dias (2014), o modelo de Black \& Scholes (BSOPM, sigla de Black \& Scholes Option Pricing Model) considera algumas premissas importantes, entre elas: (1) as opções são somente do tipo europeia (call e put), já que requerem uma data de decisão pré-estabelecida, (2) os preços do ativo devem seguir um movimento geométrico browniano (MGB), (3) os retornos em tempo contínuo (também chamados retornos logarítmicos) dos preços do ativo seguem a distribuição lognormal. Ao se construir um portfólio, é definido o valor da opção, e o payoff do portfólio é igual ao payoff da opção.

Segundo Marques \& Cruz (2015), a principal vantagem do modelo de Black \& Scholes se dá pela sua simplicidade, que requer a utilização de poucas variáveis para calcular o preço da opção, entre elas: o valor inicial do ativo, o tempo restante 
até o vencimento da opção, o preço de exercício, o taxa de retorno neutra ao risco e a volatilidade do ativo.

A principal desvantagem do modelo envolve alguns de seus pressupostos (ex: preço, volatilidade e duração), de modo que elas limitam o uso dessa abordagem como um conhecimento financeiro avançado. Segundo os autores, a fórmula do modelo BSOPM carece de transparência e intuição, e por conta disso, torna-se difícil a aplicação dessa abordagem em projetos de engenharia complexos e de larga escala.

\subsubsection{Modelo binomial}

O modelo binomial de precificação de opções desenvolvido por Cox, Ross \& Rubinstein (1979) permite a criação de uma representação simples da evolução de um ativo específico, baseado no argumento de neutralidade ao risco. O modelo consiste em um conjunto de fatores multiplicativos sequenciais organizados em formato de árvores de decisão, em tempo discreto.

Segundo Marques \& Cruz (2015), no modelo binomial, o cálculo do valor da opção é definido a partir do valor de um ativo específico $S$ em um período inicial 0 . Nos períodos subsequentes, o valor do ativo pode mover-se para cima, multiplicado por um parâmetro $u$ com uma probabilidade $p$ de ocorrer $(S u)$, ou para baixo, multiplicado pelo parâmetro $d$ com uma probabilidade 1 - $p(S d)$, e assim sucessivamente, em função do número de períodos calculados no projeto. Segundo Dias (2014), o modelo binomial foi desenvolvido com uma forma de aproximação do movimento geométrico browniano (MGB) utilizado na equação de Black \& Scholes (1973), assumindo que os preços estocásticos têm distribuição lognormal. A Figura 1 mostra a representação gráfica de uma árvore binomial discreta composta por três períodos. 


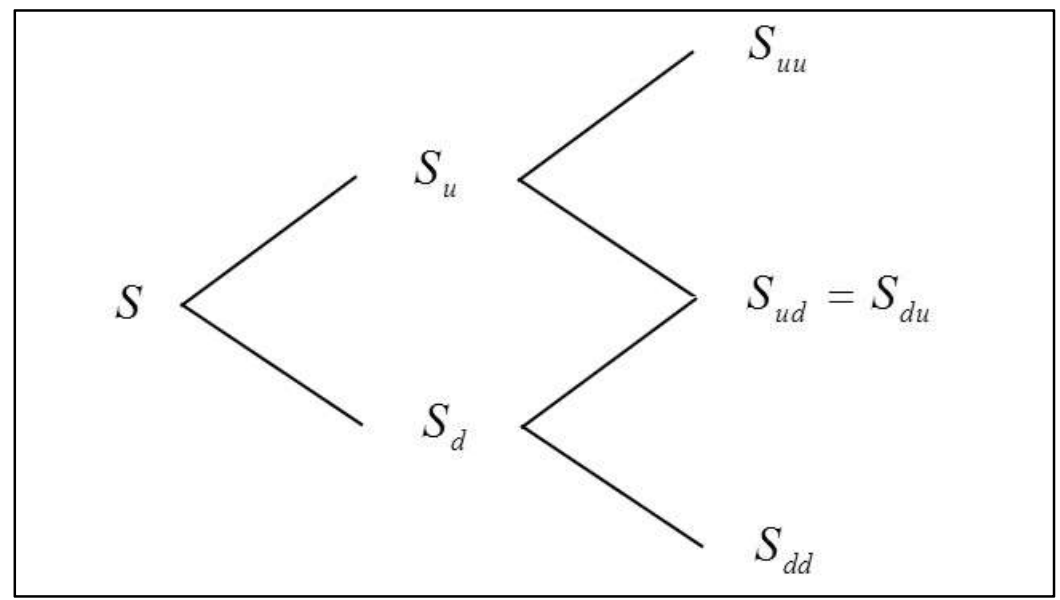

Figura 1: Árvore de decisão binomial para três períodos.

Fonte: Google Imagens, adaptado de Cox, Ross \& Rubinstein (1979).

Conforme descrito por Dias (2014), os parâmetros $u, d$ e $p$ do modelo binomial são calculados da forma demonstrada na tabela abaixo:

\begin{tabular}{|c|c|}
\hline Parâmetro & Fórmula \\
\hline$u$ & $e^{\sigma \sqrt{\Delta t}}$ \\
\hline$d$ & $e^{-\sigma \sqrt{\Delta t}}=1 / u$ \\
\hline$p$ & $\frac{(1+r)^{\sqrt{\Delta t}}-d}{u-d}$ ou $\frac{e^{r \Delta t}-d}{u-d}$ \\
\hline
\end{tabular}

Tabela 1: Parâmetros do modelo binomial de Cox, Ross e Rubinstein. Fonte: Dias (2014).

Segundo Dias (2014), o parâmetro de volatilidade $\sigma$ utilizado no modelo binomial é definido como o desvio-padrão da taxa de retorno logarítmico do ativo $S$, também usado no modelo de Black \& Scholes (1973). Ainda segundo o autor, o parâmetro de probabilidade $p$ pode ser modelado utilizando a taxa livre de risco rem tempo discreto $(1+r)^{\sqrt{\Delta t}}$ ou em tempo contínuo $\left(e^{r \Delta t}\right)$.

Dadas as múltiplas sequências de caminhos percorridos pelo valor do ativo nos movimentos binomiais, é gerado um grande conjunto de ramos (denominado árvore binomial), que trarão de forma muito aproximada o valor das mudanças ocorridas no valor do ativo em questão ao longo do tempo de vida da opção. Nesse sentido, o modelo binomial pode ser definido como uma abordagem simplificada em tempo discreto para a avaliação do preço de ativos, em comparação com o modelo de Black \& Scholes (1973). 


\subsection{Opções Reais em projetos de Infraestrutura}

Segundo Marques \& Cruz (2015), a aplicação das Opções Reais em projetos de infraestrutura teve início em 1991, com um exemplo teórico do aeroporto de Sydney. Desde o início do século XXI, a aplicação desse método em projetos de infraestrutura tem crescido amplamente, tanto em número de autores como de artigos publicados. Projetos de infraestrutura, de forma particular, incorrem diversos riscos, devido à sua natureza de longo prazo, com muitos custos afundados envolvidos e contexto incerto de cenários relacionados à demanda, custos de capital e custos de construção. A incorporação do método das Opções Reais no processo de avaliação de projetos dessa natureza permite que haja um melhor gerenciamento desses riscos, possibilitando que haja uma mensuração mais assertiva dos ganhos e perdas potenciais a que estão sujeitos.

\subsubsection{Aspectos teóricos}

\subsubsection{Timing de investimento}

Li et al (2015) discorrem sobre o processo de implementação de novos projetos de tecnologias de transporte de massa, em função da incerteza do crescimento urbano, sob a perspectiva da teoria das Opções Reais. No estudo, foram apresentados dois problemas: qual tecnologia de transportes escolher e quando introduzi-la. Segundo os autores, a teoria das Opções Reais é capaz de incorporar de forma explícita os efeitos do investimento em uma determinada tecnologia de transporte, em termos de escolhas de locais de moradia e do mercado imobiliário.

No estudo, os autores avaliaram que a escolha de um determinado sistema de transporte pode induzir a um movimento de reorganização urbana, alterando o padrão de uso do espaço, o valor das propriedades e afetando o mercado imobiliário, em termos de preços de aluguel e do espaço, e ignorar os efeitos que tal decisão gera no equilíbrio do espaço urbano pode levar a resultados inesperados e a perda do timing ideal para realizar esses investimentos.

Pimentel, Azevedo-Pereira, \& Couto (2008) desenvolveram um modelo de Opções Reais com a intuito de determinar o momento ótimo para se investir em um projeto de trem de alta velocidade, considerando uma perspectiva de tempo contínuo com uma demanda estocástica. Para a montagem do modelo, os autores definiram alguns parâmetros-base, como a demanda atual, o valor presente de 
gastos de capital, custos operacionais variáveis, taxa de desconto, o tempo de construção do projeto, volatilidade da demanda, entre outros.

\subsubsection{Prazo de concessão em regime de PPP}

Brandão \& Saraiva (2008) argumentam que as garantias e subsídios característicos de contratos de concessão em regime de PPP (parcerias públicoprivadas) podem ser modelados de forma bastante efetiva pelo método das Opções Reais, sendo uma solução particularmente importante na avaliação de projetos de infraestrutura com alto risco.

No estudo feito por Chen e Qin (2010) foi desenvolvido um método com o auxílio da teoria das Opções Reais, com o objetivo de resolver problemas relacionados a projetos públicos envolvendo entidades privadas. $O$ estudo foi aplicado ao caso de um projeto de concessão de uma rodovia.

No método proposto, um agente público ofereceria à entidade privada a opção de continuar a operar o projeto após o término do tempo de concessão. Caso a entidade privada exercesse a opção de estender o prazo da concessão, teria o direito de abandonar a operação em qualquer período ao longo da vida útil restante do projeto. Para tanto, seria necessário à entidade privada pagar um prêmio ao governo para adquirir o direito ao exercício dessa opção. Em contrapartida, o governo apreçaria o prêmio da opção em função de uma variedade de objetivos, incluindo maximização do benefício público do projeto, aumento da liquidez do projeto, e manutenção da lucratividade para a entidade privada. O prêmio pago ao governo seria utilizado para cobrir eventuais déficits de custos de operação e manutenção ou melhorar a capacidade/qualidade da infraestrutura em benefício público ao fim do ciclo de vida do projeto.

Chen \& Qin (2010) concluíram que os incentivos oferecidos pelo governo ao parceiro privado podem ser efetivamente calculados como uma opção composta, que combina uma opção de call europeia e uma opção de abandono. A proposta dos autores teve como objetivo realizar uma conciliação entre a utilidade esperada pelo investidor privado e o aumento do bem-estar social esperado pelo governo. 


\subsubsection{Evidências empíricas}

\subsubsection{Prazo de concessão em regime de PPP}

Ma et al (2018) argumentam que os métodos de decisão utilizados para determinar o tempo de concessão de projetos de PPP estão baseados principalmente nos métodos do Valor Presente Líquido (VPL), da Teoria dos Jogos e da simulação de Monte Carlo. Os autores elaboraram um modelo de Opções Reais com a finalidade de determinar não apenas o valor de uma concessão de PPP, mas também o período dela. O modelo foi aplicado ao caso real de uma estação de tratamento de esgoto localizada em Beijing.

O modelo proposto pelos autores foi construído com base no método do FCD, com a premissa que o projeto só seria considerado viável no momento em que os fluxos de caixa líquidos do projeto alcançassem o retorno esperado pelo concessionário privado. No modelo desenvolvido pelos autores, foi definido que o período de concessão do projeto seria determinado a partir da perspectiva do governo, que aprovaria o projeto quando seu valor fosse maior que zero.

Os resultados do estudo mostraram que a incorporação do método das Opções Reais no processo de avaliação do projeto acarretou uma mudança tanto do prazo como do valor da concessão, possibilitando mensurar de forma mais precisa o risco assumido pelas partes no processo de concessão e garantindo um espaço maior de negociação do governo com as companhias investidoras, levando à redução do risco dos investidores e ao aumento do poder de gestão do governo sobre o projeto. Segundo os autores, o método pode ser estendido também para a avaliação de outros projetos de PPP, como estradas, trens, aeroportos, entre outros.

\subsubsection{Subsídios governamentais}

Sitruk (2010) propôs um modelo de Opções Reais para avaliar um projeto de PPP existente de um trem de alta capacidade ligando as cidades francesas de Tours e Bourdeaux, com a finalidade de quantificar o valor da oportunidade de investimento garantida à concessionária, considerando uma demanda semiestocástica.

Silva (2018) fez uma análise do projeto do VLT Carioca, pelo método das Opções Reais. O estudo desenvolvido pelo autor buscou mensurar o retorno esperado do projeto para consórcio vencedor da licitação e avaliar o impacto dos incentivos governamentais oferecidos para a entidade privada e os custos totais 
do projeto para o Estado. O autor concluiu de que o retorno esperado do projeto para o concessionário foi relativamente pequeno em relação ao investimento realizado, e que a inclusão das garantias governamentais aumentou de forma efetiva o valor esperado do projeto, tornando-o viável do ponto de vista da entidade privada. Além disso, a realização do projeto com os incentivos governamentais gerou uma economia de aproximadamente $50 \%$ do valor total para o governo.

No estudo de Brandão et al (2012), foi feita a avaliação do projeto de concessão da Linha 4 do metrô da cidade de São Paulo, celebrado por meio de uma PPP, pela abordagem das Opções Reais. Segundo os autores, a priori, o projeto de concessão da Linha 4 mostrou ser pouco atrativo para potenciais investidores, dado o envolvimento de uma alta gama de riscos e incertezas - de modo particular, a incerteza da demanda projetada de passageiros. A fim de tornar o projeto mais atrativo para os possíveis investidores, foram oferecidos dois planos de incentivos pelo governo: uma garantia de demanda mínima e uma contraprestação pela participação no projeto, que consistiram em subsídios que funcionariam como ferramentas para mitigar os riscos da empresa que detivesse a concessão. Dessa forma, tanto a empresa como o governo assumiriam conjuntamente os riscos do projeto. O estudo dos autores mostrou que o plano de incentivos se mostrou bem-sucedido, gerando um aumento de $36 \%$ do valor esperado do projeto, a um custo de $5 \%$ do valor total do projeto para o governo.

Brandão \& Saraiva, (2008) elaboraram um modelo de garantia mínima de tráfego (MTG) por Opções Reais, aplicado ao caso da rodovia com pedágio BR163, ligando o Centro-Oeste do brasil com o Rio Amazonas. Em contraste com outros estudos que adotaram o modelo de receita mínima (MRG), no qual o ativo subjacente escolhido é o volume de tráfego, o estudo dos autores propôs um modelo no qual o prêmio de risco do volume de tráfego seria determinado de forma indireta a partir dos retornos do projeto. No estudo, as garantias governamentais foram modeladas como uma série de opções europeias independentes com maturidades entre 1 e 25 anos (tempo de concessão).

Cheah \& Liu (2006) avaliaram um projeto de construção de uma segunda via de conexão entre Cingapura e a Malásia pelo método das Opções Reais, utilizando conjuntamente os métodos da simulação de Monte Carlo e do Fluxo de Caixa Descontado, avaliando três cenários distintos (cenário-base, otimista e pessimista). Os autores modelaram também a inclusão de garantias e incentivos de PPP nos cálculos do estudo. 
No regime de incentivos avaliado no estudo, o governo pagaria um subsídio ao concessionário nos cenários em que a receita de tráfego obtida fosse inferior à receita projetada. Por outro lado, nos cenários em que a receita de tráfego fosse superior ao da receita projetada, haveria uma compensação do valor excedente do concessionário em benefício do governo. O subsídio concedido ao concessionário foi modelado como uma opção de put, enquanto que a compensação da receita excedente do concessionário para o governo foi modelada como uma opção de call. No estudo, Cheah \& Liu (2006) concluíram que é possível criar valor ao se incorporar a flexibilidade em diferentes estágios do ciclo de vida do projeto.

\subsubsection{3pção de abandono}

Diferentemente dos estudos citados até então, Law, Mackay, \& Nolan (2004) avaliaram, não uma opção de investimento em um determinado projeto, mas uma opção de abandono de um projeto - no caso, uma linha férrea. No estudo, os autores sugeriram a teoria das Opções Reais como uma abordagem mais adequada para mensurar este tipo de decisão, em contrapartida às políticas de decisão de abandono de linhas férreas. No estudo, foi feita a modelagem da incerteza do valor futuro de venda da linha férrea vendida. $O$ modelo foi aplicado a um estudo de caso de abandono de uma linha férrea canadense. Para os autores, a utilização da teoria das Opções Reais é capaz de diminuir grande parte da controvérsia envolvida nos processos de decisão pelo abandono de linhas férreas realizados do passado.

\subsubsection{Opções com incertezas e flexibilidades múltiplas}

Bowe \& Lee (2004) avaliaram pelo método das Opções Reais o caso de um implantação de uma rede de trem de alta velocidade em Taiwan (Taiwan High Speed Rail, ou THSR), celebrado por meio de uma PPP entre o governo de Taiwan e o consórcio responsável pelo projeto.

Segundo os autores, em uma análise preliminar das características do projeto, foi possível defini-lo como um projeto com uma variedade complexa de oportunidades de investimento, constituindo-se em um projeto com uma ampla gama de opções compostas entremeadas - ou seja, um projeto de opções múltiplas. No estudo, os autores avaliaram tanto o valor destas opções reais de forma individual como o valor resultante das interações entre elas. 
Entre os diferentes tipos de opções avaliadas no estudo estiveram: a (1) opção de expandir o ridership - fluxo de passageiros - (opção avaliada como uma call europeia para adquirir o direito de expandir a capacidade por meio do pagamento do investimento como preço de exercício $k$ ); a (2) opção de escalar o projeto do THSR, ou seja, operar abaixo da capacidade ou reduzir a escala de operações, preservando parte dos desembolsos planejados (opção de put no qual parte dos desembolsos do projeto pode ser reduzida, com um preço de exercício $k$ igual aos custos potenciais economizados e o prêmio da opção sendo a diferença entre o custo efetivo e o custo economizado); a (3) opção de adiar a construção do projeto por 12 meses sem penalidade, no caso de o valor esperado do projeto no ano seguinte ser superior ao valor do investimento requerido no mesmo período (opção de call do valor bruto do projeto $V$ com um preço de exercício $k$ igual ao investimento necessário no ano seguinte e o prêmio da opção sendo a diferença entre o $\mathrm{V}$ e o investimento no ano 1 , assumindo que os custos do ano 1 serão maiores que no ano 0 ).

Os resultados do estudo de Bowe \& Lee (2004) evidenciaram que a interação entre as opções compostas geralmente faz com que seus valores individuais sejam não-aditivos, e que os valores das opções compostas constituem um componente bastante significante do valor total do projeto original. $\mathrm{Na}$ Tabela 2, foi feito um breve resumo dos estudos sobre Opções Reais aplicada à projetos de infraestrutura abordados nesta seção. Nela estão detalhados os autores, os tipos de projeto avaliados, as opções avaliadas e as respectivas variáveis de incerteza:

\begin{tabular}{|l|l|l|l|}
\hline Autor citado & $\begin{array}{l}\text { Projeto de } \\
\text { infraestrutura avaliado }\end{array}$ & Opção avaliada & $\begin{array}{l}\text { Variável de } \\
\text { incerteza }\end{array}$ \\
\hline Li et al (2015) & $\begin{array}{l}\text { Projetos de transporte de } \\
\text { massa }\end{array}$ & Timing de investimento & $\begin{array}{l}\text { Crescimento da } \\
\text { população urbana }\end{array}$ \\
\hline $\begin{array}{l}\text { Pimentel, Azevedo } \\
\text { e Couto (2008) }\end{array}$ & $\begin{array}{l}\text { Projeto de trem de alta } \\
\text { velocidade }\end{array}$ & Timing de investimento & $\begin{array}{l}\text { Demanda de } \\
\text { passageiros }\end{array}$ \\
\hline Chen e Qin (2010) & $\begin{array}{l}\text { Concessão de uma } \\
\text { rodovia }\end{array}$ & $\begin{array}{l}\text { Extensão da concessão } \\
\text { e/ou abandono da } \\
\text { concessão }\end{array}$ & Nível de tráfego \\
\hline $\begin{array}{l}\text { Ma, Du e Wang } \\
\text { (2018) }\end{array}$ & $\begin{array}{l}\text { Planta de tratamento de } \\
\text { esgoto }\end{array}$ & $\begin{array}{l}\text { Prazo de concessão } \\
\text { total }\end{array}$ & $\begin{array}{l}\text { Quantidade de } \\
\text { esgoto tratado }\end{array}$ \\
\hline Sitruk (2010) & $\begin{array}{l}\text { Projeto de linha } \\
\text { ferroviária }\end{array}$ & Timing de investimento & $\begin{array}{l}\text { Demanda de } \\
\text { passageiros }\end{array}$ \\
\hline Silva (2018) & $\begin{array}{l}\text { Concessão de uma linha } \\
\text { de trem leve }\end{array}$ & $\begin{array}{l}\text { Incentivos } \\
\text { governamentais }\end{array}$ & $\begin{array}{l}\text { Demanda de } \\
\text { passageiros }\end{array}$ \\
\hline $\begin{array}{l}\text { Brandão el al } \\
\text { (2008) }\end{array}$ & $\begin{array}{l}\text { Concessão de uma linha } \\
\text { ferroviária }\end{array}$ & $\begin{array}{l}\text { Incentivos } \\
\text { governamentais }\end{array}$ & $\begin{array}{l}\text { Demanda de } \\
\text { passageiros }\end{array}$ \\
\hline Chea e Liu (2006) & $\begin{array}{l}\text { Construção de uma } \\
\text { rodovia }\end{array}$ & $\begin{array}{l}\text { Incentivos } \\
\text { governamentais }\end{array}$ & Nível de tráfego \\
\hline
\end{tabular}




\begin{tabular}{|l|l|l|l|}
\hline Bowe e Lee (2004) & $\begin{array}{l}\text { Concessão de trem de } \\
\text { alta velocidade }\end{array}$ & $\begin{array}{l}\text { Expansão de } \\
\text { capacidade, } \\
\text { escalamento, } \\
\text { adiamento }\end{array}$ & $\begin{array}{l}\text { Demanda de } \\
\text { passageiros }\end{array}$ \\
\hline $\begin{array}{l}\text { Law, Mackay e } \\
\text { Nolan (2004) }\end{array}$ & Venda de linha ferroviária & Abandono & $\begin{array}{l}\text { Valor da linha } \\
\text { férrea }\end{array}$ \\
\hline
\end{tabular}

Tabela 2: Estudos de Opções Reais aplicados à projetos de infraestrutura.

Fonte: $\mathrm{O}$ autor. 


\section{Bus Rapid Transit (BRT)}

\subsection{Definição}

Wirasinghe et al (2013) definem o BRT como um serviço de ônibus operado com base em serviços de embarques e paradas limitados e em vias de acesso separadas. Segundo os autores, o conceito do BRT surgiu na década de 1930 na cidade de Chicago, onde foi inicialmente sugerida a conversão de três linhas de trem para operar serviços expressos de ônibus em vias de acesso livre. Entretanto, o sistema foi implantado com sucesso pela primeira vez na cidade de Curitiba, no Brasil, em 1973 (Babalik-Sutcliffe \& Cengiz, 2015).

Os autores afirmam que a introdução do sistema BRT trouxe benefícios econômicos, social e ambientais em muitas das cidades que adotaram esse sistema de transporte. No entanto, eles acentuam também que a obtenção de tais benefícios variou amplamente de uma cidade para outra.

Entre as vantagens percebidas pelo sistema BRT, Wirasinghe et al (2013) apontam ele exerce um papel importante na questão da redução da poluição do ar, pode induzir ao crescimento da densidade populacional em torno dos nós de trânsito por onde passa e pode alterar a distribuição de uso de terreno em uma área metropolitana. Por outro lado, os autores afirmam também que alguns obstáculos de caráter político, como a falta de conscientização clara sobre os atributos do sistema e a ausência de monitoramento da gestão pública sobre o sistema podem constituir empecilhos no alcance eficaz dessas vantagens.

Dependendo da configuração da sua infraestrutura, o BRT pode ser classificado na categoria de sistema de baixa a média capacidade, variando entre 15.000 e 35.000 passageiros por hora por sentido. Segundo Wirasinghe et al. (2013), existem três elementos-chave que determinam o nível de capacidade de um sistema BRT: (1) a capacidade de carregamento de passageiros de um veículo BRT, (2) a capacidade de passageiros nas estações de um determinado corredor BRT, e (3) a capacidade de veículos circulando em um corredor BRT. Os autores assinalam que limitações ocorridas em pelo menos um destes elementos acarretam restrições no funcionamento de todo o sistema BRT. 


\subsection{Panorama histórico do BRT ao redor do mundo}

A opção por implantar o sistema de transporte BRT tem sido prevalente em algumas regiões do mundo em função do seu custo-benefício. Nelson et al (2013) fizeram um estudo sobre os efeitos da implantação do sistema BRT na cidade americana de Eugene-Springfield, tendo em vista os custos do projeto e o tamanho modesto da população da cidade (cerca de 300 mil habitantes e 140 mil trabalhadores na área urbana). Os autores evidenciaram que a opção pelo BRT como sistema de transporte de massa se mostrou bem-sucedida, influenciado no crescimento da taxa de empregos de áreas próximas às estações do sistema.

Babalik-Sutcliffe \& Cengiz (2015) explicam o caso do sistema BRT de Curitiba, que foi implementado em 1973 - sendo também o primeiro do Brasil e também do mundo - e foi concebido como um instrumento aliado a um plano de crescimento urbano de longo prazo, com propostas previstas de aumento do número de corredores, referidos como "eixos estruturais", que agiriam como "espinhas dorsais" do planejamento da cidade.

O sistema BRT TransMilenio, localizado na cidade de Bogotá, na Colômbia, foi introduzido no ano 2000 e atualmente figura como a maior rede de transporte por BRT do mundo, com capacidade observada de transporte de mais de 40.000 passageiros por hora por direção. Localizado em uma região metropolitana de mais de sete milhões de habitantes e com um alto nível de densidade demográfica (240 habitantes por hectare), o BRT TransMilenio de Bogotá foi introduzido com premissa de ser uma solução criativa e sustentável para problemas de mobilidade urbana característicos de grandes metrópoles (Ministério das Cidades, 2008).

Por outro lado, houve casos em que a escolha do BRT como solução de transporte de massa não alcançou os resultados esperados, como, por exemplo, o caso do sistema BRT na cidade de Istambul. Segundo Babalik-Sutcliffe \& Cengiz (2015), o BRT de Istambul, inaugurado em 2007, foi introduzido tendo com base na premissa de fácil implementação a custos baixos. No entanto, apesar do sucesso inicial, a demanda crescente de passageiros culminou em um processo de saturação do sistema, que chegou ao seu limite apenas quatro anos após sua inauguração.

De fato, o plano diretor de algumas das cidades que adotaram o sistema BRT já previam a implantação de modos de transporte de alta capacidade, como o metrô e o trem. No entanto, por conta de questões de cunho político e contingencial, a opção por introduzir o BRT em detrimento de outras propostas de modos de transporte previamente concebidas mostrou-se mais conveniente. $\mathrm{O}$ 
próprio sistema BRT TransMilenio figura entre um destes casos, visto que sua implementação precedeu o abandono de propostas de modos de transportes de trilho em favor da adoção de tecnologias baseada em ônibus menos onerosas do ponto de vista de investimentos de capital. Puyana, Rodríguez, \& Fonseca (2017) relatam que, apesar do sucesso observado inicialmente, com o passar do tempo, o BRT TransMilenio passou a apresentar uma série de problemas (aumento do preço das tarifas, ineficiência em satisfazer a demanda crescente de usuários, problemas de corrupção, entre outros), que se intensificaram e culminaram em uma crise multidimensional (financeira, sociocultural, urbana e políticoadministrativa), pondo em cheque a credibilidade desse sistema de transporte na cidade. O sistema BRT da cidade de Beijing foi inaugurado tendo em vista a necessidade de atender a demanda logística urgente para a realização das Olimpíadas de Verão de 2008 que ocorreram na cidade. No caso da Cidade do México, por outro lado, a decisão de introdução do sistema BRT decorreu não a partir de um projeto previsto para a a sua implantação, mas a partir de uma sugestão contingencial, visto que não havia até então um planejamento previsto para a sua implantação no plano diretor da cidade (Babalik-Sutcliffe \& Cengiz, 2015).

\subsection{0 sistema BRT no Rio de Janeiro}

\subsubsection{BRT Rio e os grandes eventos}

Na década de 2010, a cidade do Rio de Janeiro foi escolhida para sediar dois grandes eventos mundiais: a Copa do Mundo de 2014 e as Olimpíadas de Verão de 2016. Segundo Kassens-Noor et al (2018), desde 1988, as Olimpíadas serviram como catalisadores para a realização de grandes transformações urbanas e dos sistemas de transporte das cidades que sediaram o evento, conforme ele crescia em escopo e em escala. De forma similar, a cidade do Rio de Janeiro, sede das Olimpíadas de 2016, passou por um processo de grandes transformações em sua infraestrutura de transporte urbano, desde a extensão da rede metroviária até a inauguração de um novo sistema de transporte: o BRT. Os autores afirmam que, em comparação com outras cidades que sediaram as Olimpíadas, o Rio de Janeiro foi um caso particular, por ter sido a primeira cidade anfitriã na qual o BRT desempenhou um papel fundamental como solução de transporte para atender à demanda do evento - em conjunto com o metrô e o trem. 
Em seu estudo, Kassens-Noor et al (2018) examinam o processo de planejamento de transporte público na cidade Rio de Janeiro e suas consequências. Os autores argumentam que a percepção positiva acerca de atributos associados ao BRT (baixo custo e velocidade de implementação), o conhecimento das melhores práticas, as coalizões políticas, a facilidade para aquisição de terrenos e a flexibilidade de planejamento foram fatores que fundamentaram a escolha desse sistema como a principal solução de transporte para a atender as necessidades logísticas dos grandes eventos que ocorreram na cidade - de modo particular, as Olimpíadas de 2016.

\subsubsection{Características do BRT Rio de Janeiro}

O corredor BRT TransOeste foi o primeiro corredor do sistema troncoalimentador a ser implementado no município do Rio de Janeiro, no ano de 2012, contado com $55 \mathrm{~km}$ de pista exclusiva, 63 estações e três terminais (Alvorada, Santa Cruz e Campo Grande). Em 2014, foi inaugurado o segundo corredor do sistema, o BRT TransCarioca, atravessando as Zonas Oeste e Norte do município carioca, em um trecho de $39 \mathrm{~km}$ de extensão e composto por 45 estações e 2 terminais (Alvorada e Galeão), além de possuir integração com a Linha 2 do metrô e com os trens da SuperVia. Em 2016, foi inaugurado o terceiro corredor, o BRT TransOlímpica, possuindo $26 \mathrm{~km}$ de extensão, 18 estações e quatro terminais (Alvorada, Recreio, Centro Olímpico e Sulacap). Também em 2016, foi implementado o Lote Zero, que consiste no trecho de estações compreendido entre o terminal Jardim Oceânico e o terminal Alvorada e com integração do sistema com a Linha 4 do metrô do Rio.

Na Figura 2, é apresentado o mapa atual do sistema BRT da cidade do Rio de Janeiro, discriminando os corredores (TransOeste, TransCarioca, TransOlímpica e TransBrasil, ainda em construção), as estações e terminais, além das integrações com os trens da SuperVia e com o Metrô Rio. 


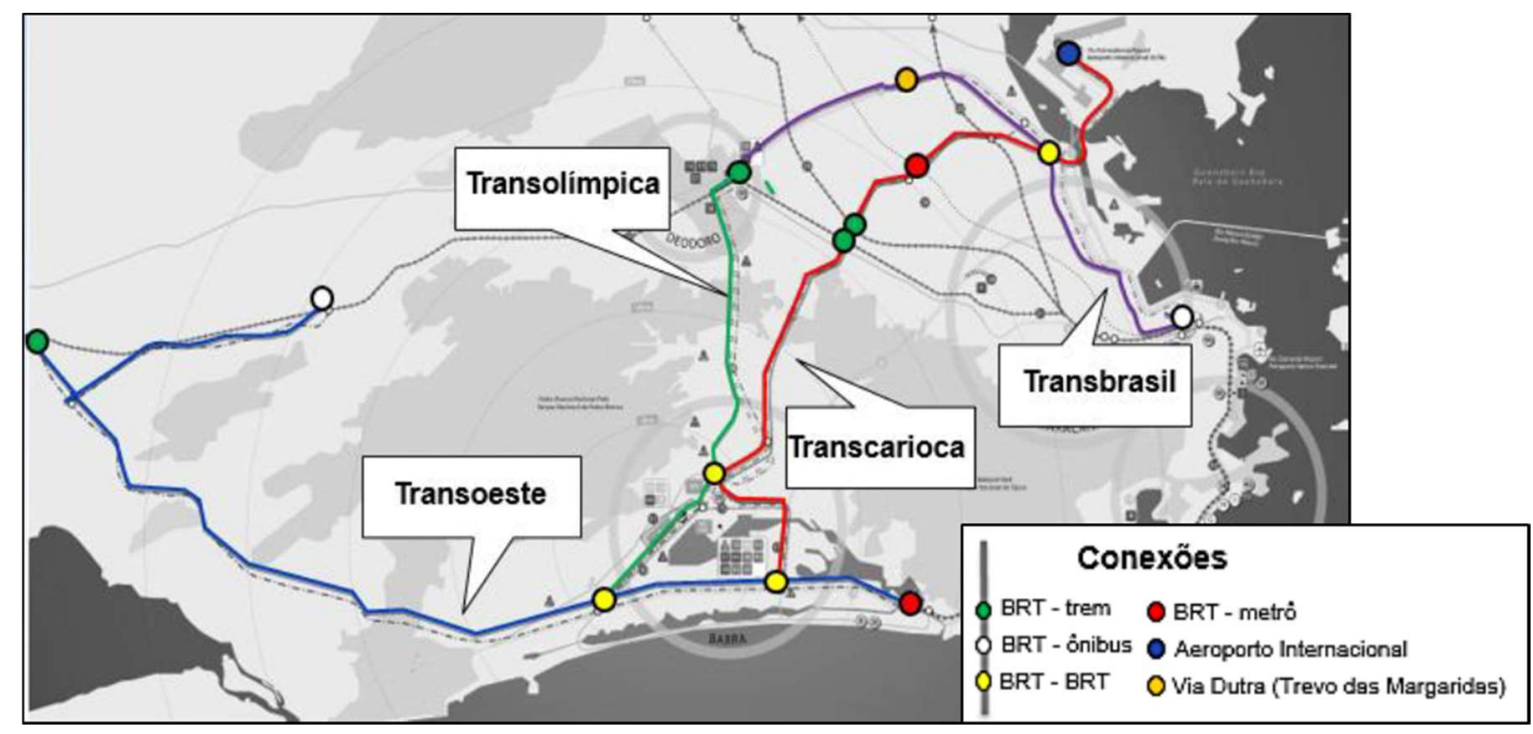

Figura 2: Corredores do sistema BRT Rio.

Na Figura 3, estão ilustrados os dois tipos de veículos que circulam nos corredores do sistema BRT do Rio de Janeiro: os veículos do eixo troncal (à esquerda) e os veículos alimentadores (à direita). Segundo Campos (2014), o veículo do eixo troncal é dotado de computador de bordo, câmbio automático, controle eletrônico de velocidade, suspensão pneumática com bolsões de ar, câmeras internas e externas online, monitoramento por GPS, sistema de comunicação com o Centro de Controle Operacional (CCO), ar condicionado, TV digital e aviso sonoro de paradas. Por ser um veículo articulado, é capaz de transportar uma quantidade maior de passageiros e circula nas vias troncais, utilizando o sistema viário principal, estabelecendo ligação entre o terminal e os principais polos de atração ou produção de viagens da região.

O veículo alimentador, por sua vez, possui a função de captar ou distribuir usuários das adjacências que orbitam o eixo troncal do sistema BRT. Possuem ar-condicionado, monitoramento por GPS e câmeras. Em geral, é composto por linhas de pequena extensão e circulam em vias coletoras.
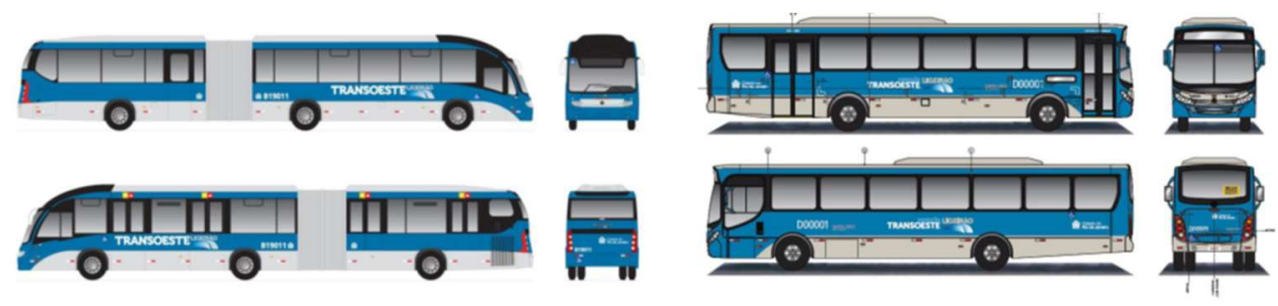

Figura 3: Veículos do eixo troncal e veículos alimentadores do BRT Rio. 


\subsection{0 contexto do BRT do Rio pós-Olimpíadas}

A introdução do novo sistema BRT do Rio de Janeiro teve um papel importante na questão da mobilidade urbana da cidade, reduzindo significativamente o tempo de deslocamento e convertendo-se em uma importante via de interligação entre os bairros da Zona Oeste da cidade - particularmente no trecho que interliga os bairros de Santa Cruz e Campo Grande em direção ao Recreio e à Barra da Tijuca, cuja única opção de transporte de massa disponível até então era a rede de serviço de ônibus convencional. Contudo, apesar do aparente sucesso inicial, começou a ser notado o surgimento de uma série de problemas que passaram a prejudicar o desempenho desse sistema com o passar do tempo. A crescente escalada desses problemas se agravou até o ponto de ser requerida uma intervenção do Poder Concedente (Prefeitura do município do Rio de Janeiro) nas operações do sistema BRT, com a finalidade de averiguar, entre outras coisas, a origem e a causa desses problemas, bem como a busca de soluções para os mesmos, além de avaliar a forma como o sistema vinha sendo gerido pelo concessionário responsável. A intervenção foi instituída pelo decreto 45.640/19 da Prefeitura do Rio de Janeiro e realizada entre os meses de janeiro e julho do ano de 2019, em obediência ao exposto no Artigo 34 da Lei 8.987/95, onde está prevista a intervenção do Poder Concedente (no caso, a prefeitura do município do Rio de Janeiro), quando da necessidade de se assegurar a plena prestação do serviço e do cumprimento das normas contratuais, regulamentares e legais da concessão (Diário Oficial da República Federativa do Brasil, 1995). Ao término do período de intervenção foi elaborado um relatório final, no qual foram descritos os estudos realizados acerca do desempenho operacional do sistema BRT do Rio, além de informações relativas ao contexto no qual ele se encontrava.

No relatório final da intervenção, foi constatado que, desde o início das operações, foi percebido um descompasso entre a demanda de passageiros estimada e a demanda de passageiros efetivamente realizada nos três corredores BRT. Segundo o relatório, havia uma estimativa de demanda de aproximadamente 135.000 passageiros transportados diariamente no corredor BRT TransOeste, com ridership (fluxo de passageiros) máximo de 15.000 passageiros/hora. No entanto, o relatório descreve que, atualmente, o corredor apresenta números bastante superiores aos inicialmente previstos, com números superiores a 180.000 passageiros transportados diariamente, o demonstra que o corredor BRT TransOeste alcançou um quadro de saturação da sua capacidade em um curto espaço de tempo. 
Entre as causas que podem ter contribuído para o quadro de saturação do corredor BRT TransOeste, o relatório cita: (1) a má distribuição da frota de veículos entre os corredores, resultado de um planejamento operacional ineficiente, fazendo com que haja insuficiência de veículos para atender a demanda do BRT TransOeste e subutilização da frota em outros corredores, que possuem demanda de passageiros inferior; (2) não-cumprimento do limite de frota determinada pelo Poder Concedente; (3) diminuição da frota operante ao longo dos anos devido à precariedade na manutenção do material rodante e à saída ou falência de operadoras consorciadas, (4) gastos de capital investidos desnecessariamente na construção de estações com demanda muito baixa de passageiros, (5) subdimensionamento do projeto das estações e ausência de terminais adequados para comportar adequadamente a demanda de passageiros do sistema, (6) condições de infraestrutura inadequadas para a circulação das composições (especialmente no corredor BRT TransOeste), ocasionado a quebra e a deterioração da frota e agravando ainda mais situação da disponibilidade de frota, e (7) manutenção extremamente onerosa do sistema.

Os estudos do relatório constataram ainda que o sistema BRT do Rio sofre com um elevado índice de evasão de passageiros, na ordem de 74.000 passageiros por dia. Segundo o relatório, estes passageiros aproveitam-se da vulnerabilidade da arquitetura das estações dos eixos troncais e as invadem sem passar pelas bilheterias ou pelas catracas de bilhetagem eletrônica e viajam sem pagar a tarifa. Esta situação representa um índice de evasão de receitas de aproximadamente $\mathrm{R} \$ 185.000$ por dia (cerca de $\mathrm{R} \$ 5.000 .000$ por mês), que afeta diretamente o desempenho econômico-financeiro do sistema.

Nos estudos realizados ao longo do período de intervenção, evidenciou-se que parte significativa dos problemas atualmente enfrentados no sistema BRT do Rio estão indiretamente associados à questões de âmbito jurídico-legal, desde a forma como o serviço público de operação do BRT da cidade foi licitado e concedido até a constituição jurídica do consórcio responsável pelas operações do sistema.

Tendo em vista os pontos críticos identificados no período em que durou a intervenção do Poder Concedente do sistema BRT do Rio, foi proposto um conjunto de ações a serem tomadas no intuito de melhorar a situação na qual o sistema se encontrava, entre as quais: desativação de estações com demanda muito baixa de passageiros; readequação física das estações e terminais; intensificação do combate efetivo à evasão de passageiros; além da necessidade 
de reformulação tanto do modelo de concessão como do próprio consórcio operacional que opera o BRT do Rio.

\subsection{Série histórica da frota diária do corredor TransOeste}

Nesta seção, foi feita uma análise comparativa, no intuito de analisar a evolução do desempenho operacional do corredor BRT TransOeste, relacionando conjuntamente a quantidade de passageiros transportados no corredor em horário de pico e frota de veículos disponível para atender a demanda de todo o corredor. A Figura 8 mostra o comparativo das duas séries históricas entre janeiro de 2016 e março de 2019. Na série histórica analisada, foram considerados somente os dias operacionais entre segunda e sexta-feira - ou seja, os dias úteis. Considerando que alguns desses dias úteis também foram feriados (nos quais existe usualmente uma redução da frota e da demanda de passageiros em comparação com dias úteis normais), ocorreram naturalmente alguns episódios de queda mais acentuada tanto na demanda de passageiros em horário de pico como no tamanho da frota de veículos. Os eventos relevantes ocorridos no período analisado, com grande variação de demanda, foram destacados com legendas e setas vermelhas.

BRT TransOeste - Frota diária x Demanda de pico diária DU
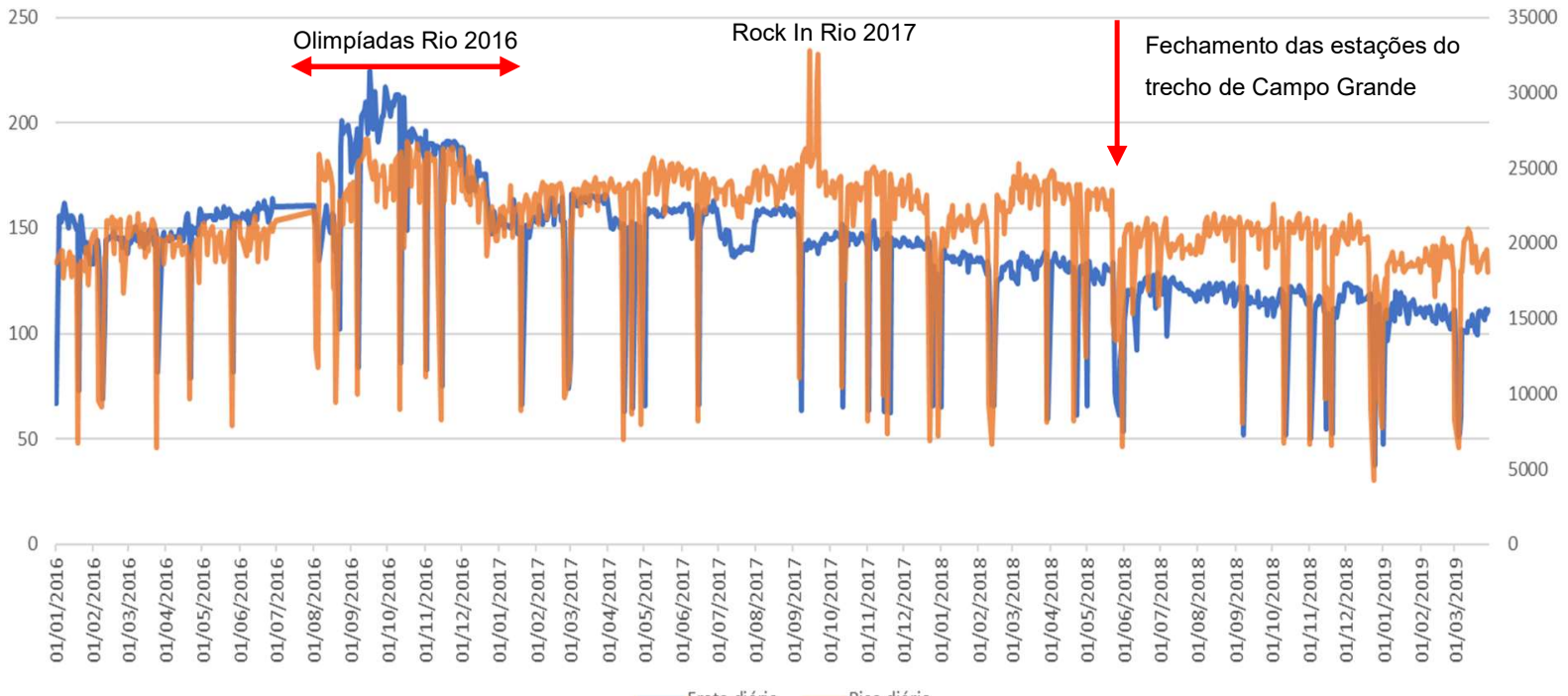

Figura 4: Comparativo da frota diária $\mathrm{x}$ demanda de pico diária por dia útil. Fonte: Base de dados disponibilizada pelo Consórcio Operacional BRT.

Analisando as duas séries históricas conjuntamente, foi possível identificar que, a partir de setembro de 2017, houve uma tendência de diminuição do 
tamanho da frota de veículos disponível para atender a demanda diária de passageiros transportados no corredor BRT TransOeste, muito em virtude dos pontos descritos no relatório da intervenção, como a saída de empresas do consórcio, a preferência das empresas do consórcio em operar em outros corredores, a retirada de veículos ocasionada por quebras decorrentes de atos de vandalismo e das más condições de rodagem no eixo troncal, além da desativação de um trecho de mais de vinte estações do corredor.

No entanto, ao se comparar o cenário da demanda de passageiros transportados em horário de pico do final de 2018 e início de 2019 com o cenário observado no ano de 2016 - período no qual o nível de capacidade operacional do corredor atingiu seu ápice -, foi possível notar que não houve uma variação significativa da demanda de passageiros no horário de pico, tendo ela se mantido em um nível relativamente estável. Esta situação mostra que, apesar da tendência percebida de diminuição do tamanho da frota de veículos ao longo do anos e, de modo particular, da desativação de um trecho inteiro de estações localizadas ocorrida em junho de 2018 na região do bairro de Campo Grande, existe um potencial de demanda do corredor BRT TransOeste passível de ser explorado.

No entanto, o atendimento desta demanda de passageiros potencial está condicionado primeiramente à necessidade de readequação da configuração operacional do corredor, com a ampliação do tamanho da frota de veículos e também com o redimensionamento das estações do eixo troncal que se encontram em estado de saturação da capacidade. Tendo em vista estes pontos, este estudo foi desenvolvido com a finalidade de mensurar o ganho potencial advindo da readequação da configuração operacional do corredor BRT TransOeste. Vale ressaltar que a análise de expansão da capacidade da demanda de passageiros desenvolvida neste estudo se aplicou exclusivamente ao caso do corredor BRT TransOeste, ou seja, não foi levada em consideração a inclusão de informações referentes aos demais corredores do sistema BRT do Rio. 


\section{Metodologia}

\subsection{Estrutura da pesquisa}

As etapas desenvolvidas para a realização do presente estudo foram estruturadas conforme o esquema detalhado na Figura 5:

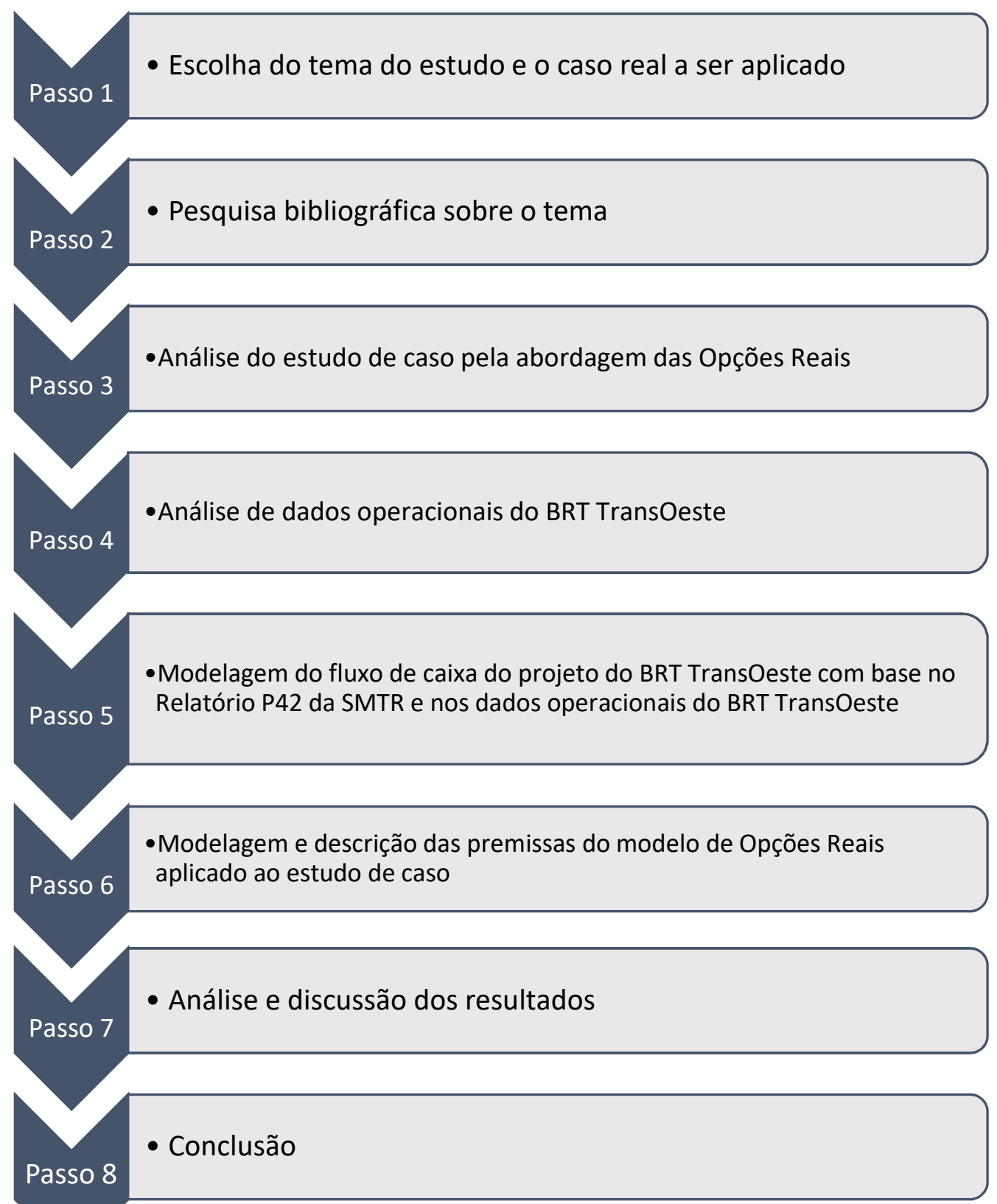

Figura 5: Metodologia de pesquisa. Fonte: o autor. 
O passo 1 descrito na Figura 4 consistiu na escolha do tema escolhido como objeto de estudo e na escolha do caso real sob o qual o estudo foi desenvolvido. Estes dois fatores nortearam o embasamento teórico posterior.

No passo 2 foi feita a pesquisa bibliográfica, com o propósito de embasar e exemplificar a aplicação da teoria das Opções Reais em projetos de infraestrutura, estudos relativos ao modo de transporte BRT, com uma breve contextualização de sistemas BRT existentes ao redor do mundo, além do próprio sistema BRT do Rio de Janeiro. Na fase de pesquisa bibliográfica, foram realizadas pesquisas em periódicos, papers, teses e dissertações relacionadas com tema desenvolvido neste estudo. Foram utilizadas as bases de dados EBSCO e Scopus, a plataforma Google Scholar e o acervo de livros da Biblioteca Central da PUC-Rio.

O passo 3 consistiu na análise do estudo de caso escolhido pela abordagem das Opções Reais, ou seja, a possibilidade de mensurar o valor da opção de expansão da capacidade operacional do corredor BRT TransOeste.

No passo 4, foi feita a análise de informações referentes ao corredor BRT TransOeste com base em dados operacionais fornecidos pelo Consórcio Operacional e no relatório de intervenção. Entre as informações analisadas nesta etapa estão a série histórica de passageiros transportados no corredor BRT TransOeste e o estudo de planejamento do tamanho da frota de veículos.

O passo 5 consistiu na modelagem do fluxo de caixa do projeto adaptado para a finalidade deste estudo. O fluxo de caixa do projeto foi montado com base no Relatório P42 da Secretaria Municipal de Transportes do Rio de Janeiro (SMTR). Este relatório foi desenvolvido com a finalidade de avaliar dos fluxos de caixa dos consórcios responsáveis pelo serviço de transporte público de ônibus da cidade - entre eles, o próprio BRT. A estrutura do fluxo de caixa foi montada com o auxílio do software Microsoft Excel ${ }^{\mathrm{TM}}$. Os parâmetros adotados no cálculo dos valores do fluxo de caixa do projeto foram desenvolvidos com base nos dados operacionais analisados na etapa anterior e dos dados descritos no próprio Relatório P42 da SMTR.

No passo 6, foi feita a descrição detalhada do modelo de Opções Reais desenvolvido neste estudo para calcular o valor da opção de expansão da capacidade do corredor BRT TransOeste, considerando a flexibilidade gerencial de expandir a capacidade ou de adiar essa decisão para períodos posteriores. $\mathrm{O}$ exercício destas opções ocorreu em função da incerteza da demanda de passageiros transportados no horário de pico. Foi avaliada também a variação ocorrida no valor da opção de expansão com a inclusão de incentivos governamentais. A incorporação da abordagem de Opções Reais ao estudo de 
caso em questão foi viabilizada com a utilização de dois softwares: Microsoft Exce/ ${ }^{\mathrm{TM}}$ - onde foi desenvolvida a estrutura dos fluxos de caixa do projeto, com o auxílio de planilhas eletrônicas - e o Syncopation DPL ${ }^{\text {TM }} 9$ - onde foi desenvolvido o esquema de árvores de decisão do modelo de Opções Reais. Por meio da integração entre os dois softwares, foi possível calcular o valor do projeto de expansão da capacidade do corredor BRT TransOeste.

No passo 7 , se deu a análise e a discussão dos resultados obtidos no modelo de Opções Reais. Foi feita uma análise de sensibilidade da variável de incerteza do modelo e da variação do valor do projeto com a incorporação dos incentivos governamentais. Após esta etapa, foi feita a conclusão do estudo.

\subsection{Métodos de avaliação dos resultados do estudo}

Os objetivos e resultados deste estudo foram analisados e avaliados por meio da integração de dois métodos quantitativos - o Fluxo de Caixa Descontado e o modelo binomial de precificação de opções de Cox, Ross \& Rubinstein (1979) -, sobre os quais foram aplicados dados e parâmetros relativos ao estudo de caso escolhido. Assim, foi possível mensurar a variação ocorrida no valor esperado do projeto avaliado neste estudo (o corredor BRT TransOeste), como efeito da realização de um evento específico (a expansão da capacidade operacional do corredor) ocorrido em função do processo de difusão da variável de incerteza deste projeto (a demanda de passageiros transportados em horário de pico). 


\section{Modelo de expansão da capacidade do corredor BRT TransOeste}

\subsection{Série histórica de passageiros}

A base de dados com a série histórica de passageiros transportados foi disponibilizada pelo Consórcio Operacional BRT Rio (CCO BRT-Rio), que é o órgão responsável por operar e monitorar os três corredores que compõem o sistema BRT do Rio (TransOeste, TransCarioca e TransOlímpica). Os dados foram cedidos tendo como finalidade exclusiva a elaboração deste estudo. A série histórica fornecida compreende o período entre janeiro de 2016 e março de 2019, ou seja, um período de três anos e três meses. Não foi possível obter informações referentes ao volume de passageiros transportados no período anterior a janeiro de 2016 ou após março de 2019. A Figura 6 mostra a série histórica da demanda de passageiros transportados no corredor TransOeste entre janeiro de 2016 e março de 2019.

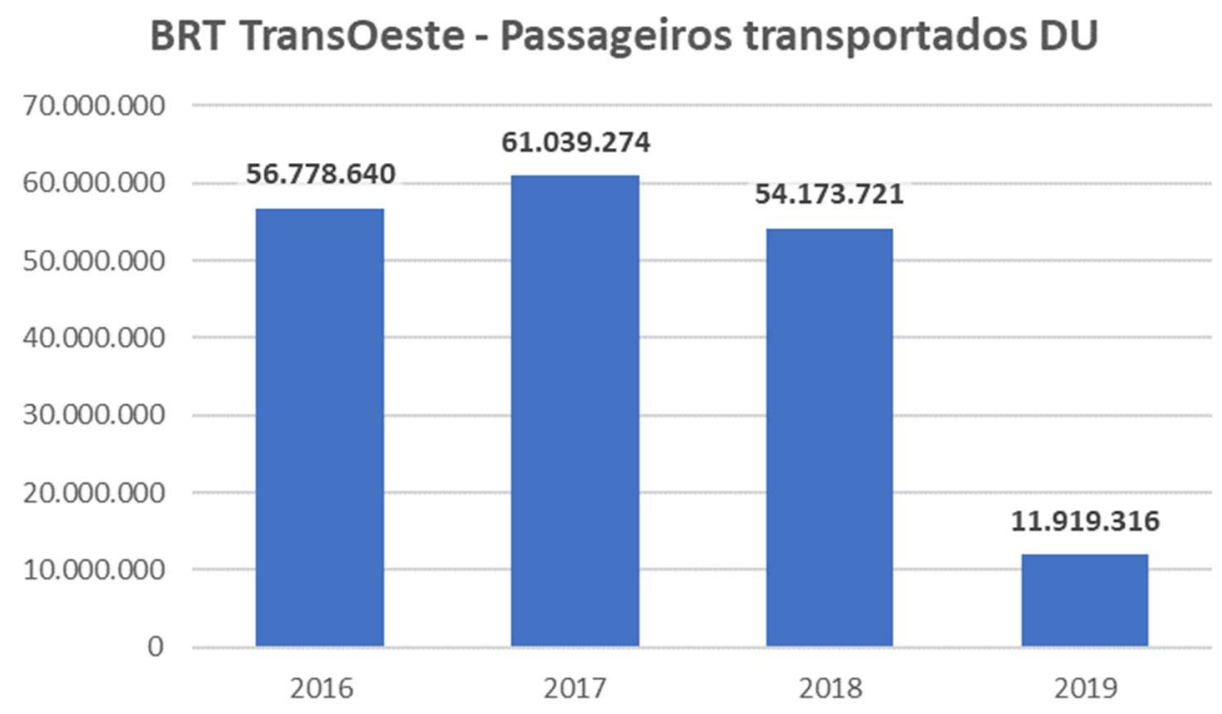

Figura 6. Passageiros transportados no BRT TransOeste em dias úteis. Fonte: Base de dados disponibilizada pelo Consórcio Operacional BRT. 


\subsubsection{Cálculo da volatilidade}

Como é possível observar na Figura 6, a série histórica do ano de 2019 está incompleta, visto que a contagem da demanda de passageiros transportados no respectivo ano corresponde somente aos meses entre janeiro e março. Em virtude disso, e, considerando também que a série histórica anual de passageiros da Figura 6 é demasiado pequena (composta por somente quatro períodos) para se obter uma taxa de volatilidade anual consistente, optou-se por estimar a taxa de volatilidade anual com base na média de passageiros transportados em cada trimestre da série histórica de dias úteis - em outras palavras, a demanda média trimestral de dias úteis. Para se obter o valor desta demanda média, foi feita a razão entre a contagem do total de passageiros transportados em cada trimestre da série histórica de dias úteis e a contagem de dias operacionais em cada trimestre da série de dias úteis. A Figura 7 mostra a demanda diária média de passageiros transportados no corredor BRT TransOeste em cada trimestre da série histórica de dias úteis:

BRT TransOeste - Passageiros transportados DU por trimestre

300.000

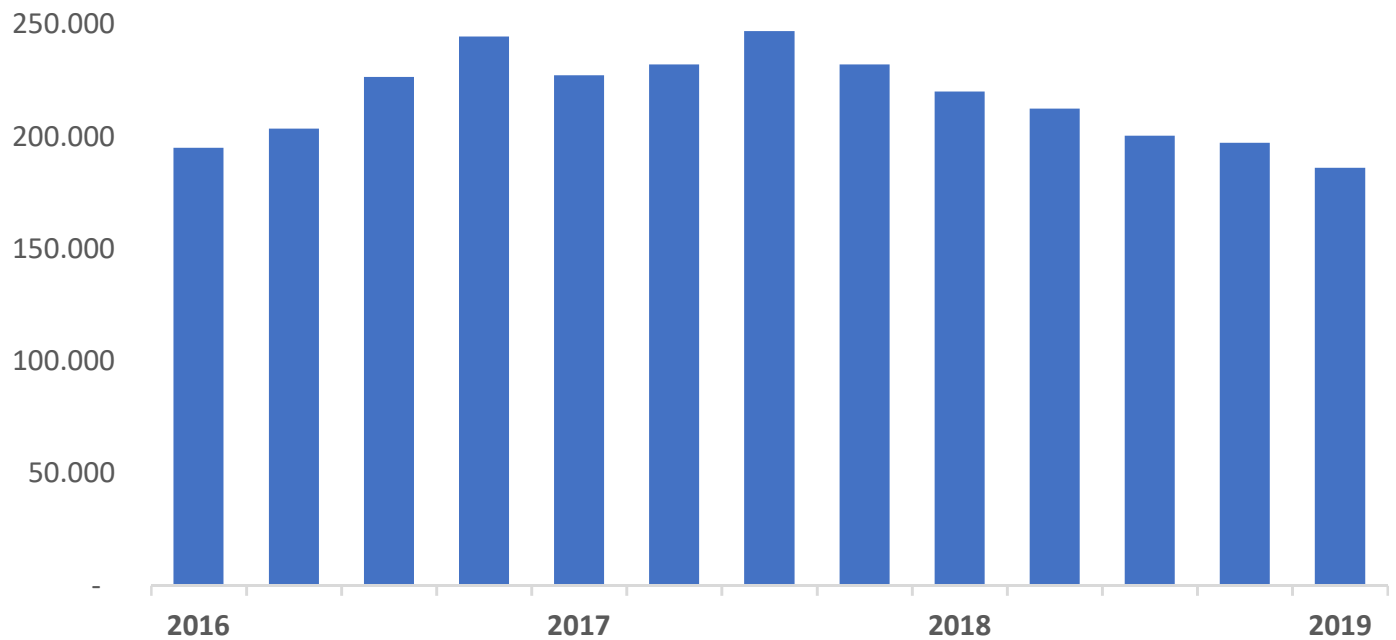

Figura 7: Demanda diária média de passageiros em dias úteis por trimestre. Fonte: Base de dados disponibilizada pelo Consórcio Operacional BRT.

Segundo Dias (2014), o valor da taxa de volatilidade de um ativo pode ser determinada pelo cálculo do desvio-padrão das variações contínuas ocorridas nos valores deste ativo ao longo do tempo. Aplicando-se esta regra à série de dados da demanda média trimestral descrita na Figura 7, foi possível estimar uma taxa de volatilidade no valor de $6,02 \%$ ao trimestre. Dado que esta taxa de volatilidade 
foi calculada sobre uma série histórica trimestral e que o modelo desenvolvido no estudo foi avaliado em períodos de decisão anuais, foi necessária a realização de um segundo passo, com a finalidade de anualizar o valor desta taxa de volatilidade. Multiplicando-se o valor da taxa trimestral de $6,02 \%$ pela raiz de 4 , foi possível fazer a equivalência entre a periodicidade da taxa de volatilidade trimestral e a periodicidade anual adotada no modelo avaliado neste estudo, resultando no valor de $12,04 \%$ ao ano. Dessa forma, foi adotado, por fim, o valor de $12 \%$ como o parâmetro da taxa de volatilidade anual da variável de incerteza utilizada no modelo de Opções Reais.

\subsubsection{Proporção de passageiros pagantes e não pagantes}

A contagem da série histórica de passageiros do Consórcio Operacional BRT Rio segmentou os usuários do sistema em três categorias distintas: "Valetransporte", que consiste nos usuários pagantes que utilizaram o sistema; "Gratuidade", que inclui todos os passageiros com isenção no pagamento da tarifa, como idosos, estudantes e portadores de necessidades especiais, e por último, os usuários categorizados como "Evasão", que consiste nos passageiros que utilizaram o sistema sem pagar e não se enquadram na categoria de "Gratuidade". A Tabela 3 apresenta a demanda diária média por dia útil trimestral mostrada na Figura 7, segmentada para cada um desses três tipos. Os dados referem-se somente aos passageiros transportados no corredor BRT TransOeste.

\begin{tabular}{|c|c|c|c|c|}
\hline Trimestre & $\begin{array}{c}\text { Vale- } \\
\text { transporte }\end{array}$ & Gratuidade & Evasão & Total \\
\hline T12016 & 163.391 & 17.611 & 14.153 & $\mathbf{1 9 5 . 1 5 5}$ \\
\hline T22016 & 165.658 & 18.130 & 19.763 & $\mathbf{2 0 3 . 5 5 1}$ \\
\hline T32016 & 189.407 & 14.792 & 22.521 & $\mathbf{2 2 6 . 7 2 0}$ \\
\hline T42016 & 195.085 & 27.113 & 22.405 & $\mathbf{2 4 4 . 6 0 4}$ \\
\hline T12017 & 186.395 & 20.084 & 20.854 & $\mathbf{2 2 7 . 3 3 3}$ \\
\hline T22017 & 187.678 & 24.866 & 19.763 & $\mathbf{2 3 2 . 3 0 8}$ \\
\hline T32017 & 199.575 & 26.088 & 21.461 & $\mathbf{2 4 7 . 1 2 4}$ \\
\hline T42017 & 186.341 & 23.933 & 22.026 & $\mathbf{2 3 2 . 3 0 1}$ \\
\hline T12018 & 175.902 & 19.357 & 24.924 & $\mathbf{2 2 0 . 1 8 3}$ \\
\hline T22018 & 168.085 & 19.514 & 24.868 & $\mathbf{2 1 2 . 4 6 7}$ \\
\hline T32018 & 167.032 & 16.314 & 17.148 & $\mathbf{2 0 0 . 4 9 4}$ \\
\hline T42018 & 163.498 & 15.867 & 17.898 & $\mathbf{1 9 7 . 2 6 3}$ \\
\hline T12019 & 156.049 & 12.441 & 17.749 & $\mathbf{1 8 6 . 2 3 9}$ \\
\hline
\end{tabular}

Tabela 3. Categorias de passageiros por dia útil.

Fonte: Base de dados disponibilizada pelo Consórcio Operacional BRT. 
A partir da análise dos dados do total de passageiros segmentados por categoria descritos na Tabela 3, foi possível estimar uma proporção para cada uma das três categorias de usuários do sistema. Para a finalidade da elaboração do fluxo de caixa, foram definidas premissas das proporções de cada categoria de passageiros em relação ao total de passageiros. Abaixo estão descritas as proporções das categorias de passageiros calculadas em relação à demanda diária total de passageiros. Os dados abaixo referem-se ao ano de 2019:

- Passageiros de evasão: $9,5 \%$ da demanda diária $=\left(\frac{17.749}{186.239}\right)$

- Passageiros de gratuidade: $6,7 \%$ da demanda diária $=\left(\frac{12.441}{186.239}\right)$

Essas proporções foram utilizadas para estimar a quantidade de passageiros pagantes, que foram a base de cálculo da receita tarifária do projeto.

\subsubsection{Pico diário médio de passageiros por dia útil}

Após terem sido definidos os parâmetros da volatilidade e as proporções das categorias de passageiros do sistema, o passo seguinte consistiu na análise do fluxo médio de passageiros transportados no corredor TransOeste por dia útil em cada hora do dia. A análise da demanda diária de passageiros por hora foi necessária para estimar com maior precisão a variação dos custos operacionais decorrente da variação do fluxo de passageiros ao longo das horas do dia e o tamanho da frota de ônibus estimada em cada hora do dia. Os dados discriminados na Figura 8 e na Tabela 4 referem-se à média de passageiros transportados do ano de 2019.

\section{BRT TransOeste \\ Passageiros transportados por hora DU}

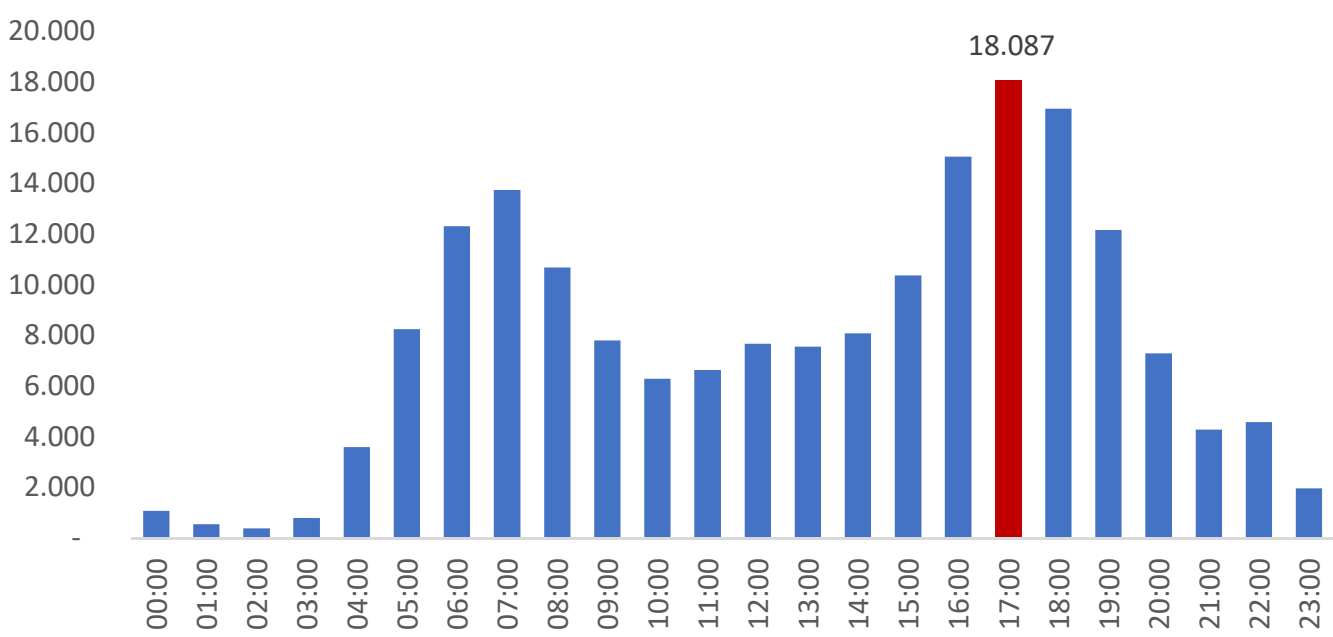

Figura 8: Demanda diária de passageiros por dia útil por hora. Fonte: Base de dados disponibilizada pelo Consórcio Operacional BRT. 


\begin{tabular}{|c|c|c|c|}
\hline Hora & $\begin{array}{l}\text { Passageiros } \\
\text { transportados }\end{array}$ & Hora & $\begin{array}{l}\text { Passageiros } \\
\text { transportados }\end{array}$ \\
\hline $00: 00$ & 1.090 & $12: 00$ & 7.680 \\
\hline 01:00 & 564 & $13: 00$ & 7.551 \\
\hline $02: 00$ & 388 & $14: 00$ & 8.084 \\
\hline 03:00 & 804 & $15: 00$ & 10.363 \\
\hline $04: 00$ & 3.602 & $16: 00$ & 15.053 \\
\hline 05:00 & 8.246 & $17: 00$ & 18.087 \\
\hline 06:00 & 12.311 & $18: 00$ & 16.949 \\
\hline $07: 00$ & 13.733 & $19: 00$ & 12.158 \\
\hline $08: 00$ & 10.684 & $20: 00$ & 7.297 \\
\hline 09:00 & 7.803 & $21: 00$ & 4.294 \\
\hline $10: 00$ & 6.294 & $22: 00$ & 4.592 \\
\hline $11: 00$ & 6.643 & $23: 00$ & 1.969 \\
\hline \multicolumn{3}{|c|}{ Total } & 186.239 \\
\hline
\end{tabular}

Tabela 4: Demanda diária de passageiros por dia útil por hora.

Fonte: Base de dados disponibilizada pelo Consórcio Operacional BRT.

$\mathrm{Na}$ análise da série histórica de passageiros transportados no corredor BRT TransOeste em cada hora do dia, foi possível constatar que os horários de pico, ou seja, os horários com maior fluxo de passageiros do corredor, correspondem aos horários de 07:00 e de 17:00. Para a finalidade deste estudo, a demanda do pico das 17:00 foi escolhida como a variável de incerteza do modelo de Opções Reais (barra na cor vermelha da Figura 8 e valor marcado em amarelo na Tabela 4) pelo fato de ser o parâmetro que mede o limite máximo de capacidade operacional do sistema.

\subsection{Estimativa da frota diária}

Para estimar o tamanho da frota de veículos necessária para atender a demanda de passageiros do corredor em cada hora do dia, foi aplicada uma fórmula citada por Ceder (1984). A fórmula tem como finalidade definir o tamanho de frota mínimo para acomodar um determinado número de passageiros transportados ao longo de um corredor em um determinado período de tempo, levando em consideração o fator de carregamento (load factor) do período e a capacidade máxima de passageiros por veículo, conforme descrito na Equação 6 .

$$
F_{i}=\frac{P_{i}}{\gamma_{i} * c}
$$

onde $F_{i}$ é o tamanho da frota de veículos do período $i, P_{i}$ é a demanda média de passageiros transportada no período $i, \gamma_{i}$ é o load factor do período $i$, e $c$ é a capacidade máxima de passageiros em um veículo (somatório do número de passageiros sentados e em pé). O load factor é um índice que representa a razão 
entre o número de passageiros transportados de um veículo e a sua capacidade total, podendo variar entre zero e 1; ou seja: quanto mais próximo de 1 for o load factor, maior será a quantidade de passageiros transportados em cada veículo e menor será o tamanho da frota de veículos para atender à demanda.

\subsubsection{Estudo de oferta de frota diária}

O Consórcio Operacional do BRT do Rio disponibilizou para análise um estudo de oferta da frota de veículos, no qual estão discriminadas informações sobre os veículos que percorrem os três corredores do sistema BRT do Rio. Entre as informações que constam neste estudo estão: o número das linhas de ônibus, os pontos de origem e destino, os horários de saída e chegada entre as estações, a quilometragem percorrida, o sentido do trajeto (ida ou volta), a quantidade de veículos disponíveis em cada hora do dia e a capacidade de passageiros transportada, além do tipo de dia (dia útil, baixa demanda, sábado e domingo).

Nos dados apresentados na Figura 9, foi feito um estudo comparativo relacionando o tamanho da frota de veículos e a capacidade de passageiros transportados por veículo disponível em cada hora do dia útil, com base no estudo de frota determinada do Consórcio Operacional BRT.

\section{BRT TransOeste - Frota diária x Capacidade máxima}

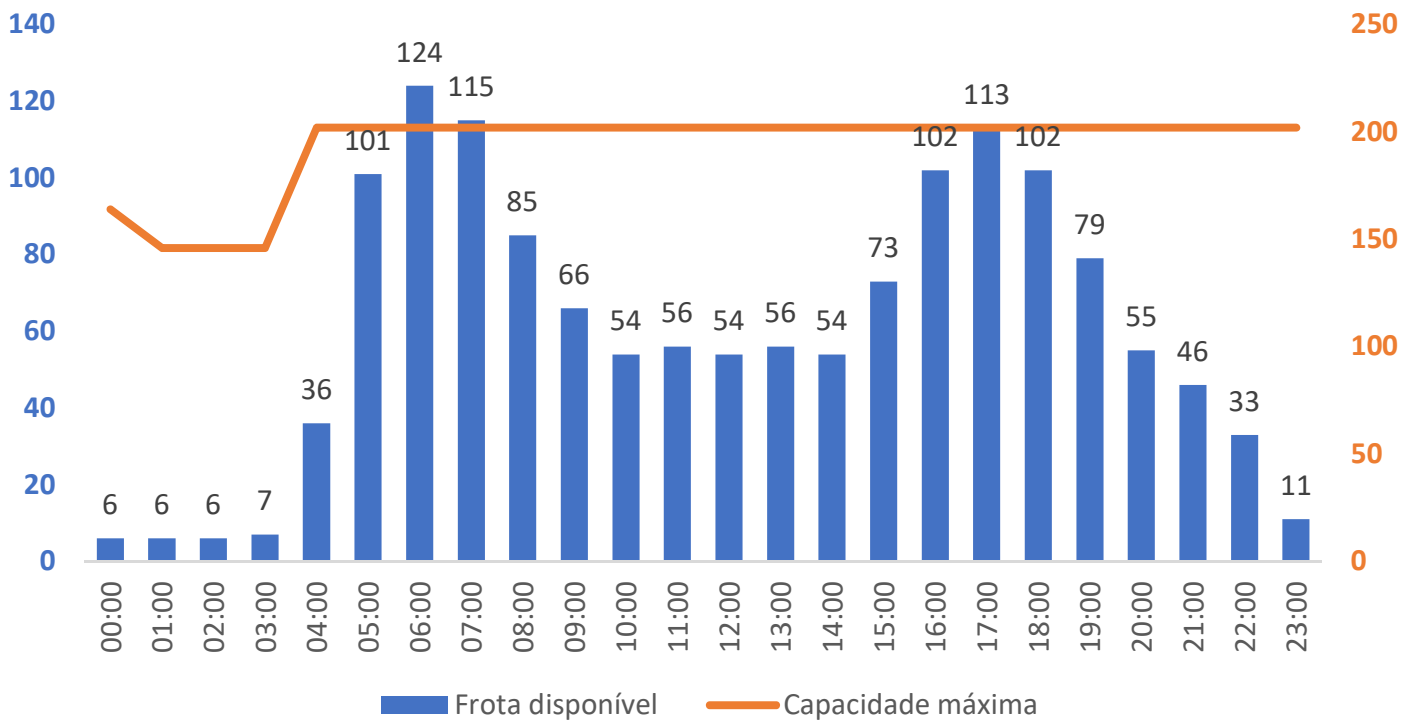

Figura 9. Frota diária $\mathrm{x}$ capacidade máxima por dia útil. Fonte: Base de dados disponibilizada pelo Consórcio Operacional BRT. 


\subsubsection{Fator de carregamento de passageiros (load factor)}

Para se calcular o tamanho da frota de veículos em cada hora do dia útil, foi necessário primeiramente determinar o load factor do sistema BRT, tomando como referência principal a demanda do horário de pico. Para se determinar o load factor, foi aplicada a fórmula de Ceder (1984) juntamente com alguns dados operacionais do sistema BRT.

Analisando as informações apresentados na Figura 9, foi possível definir dois valores: a capacidade máxima de passageiros transportados por cada veículo do sistema BRT em cada hora operacional $(c)$ - de 202 passageiros - e o tamanho da frota de veículos disponível no horário de pico das 17:00 - de 113 ônibus, somados os sentidos de ida e de volta. Assim, aplicando-se estes dois valores junto com o da demanda de pico descrita na Figura $8\left(P_{i}\right)$ na fórmula de Ceder (1984), foi possível determinar o load factor da demanda de passageiros no horário de pico $\left(\gamma_{i}\right)$, de aproximadamente 0,8 . A Tabela 5 resume os valores utilizados para determinar o $\gamma_{i}$ do sistema BRT.

\begin{tabular}{|c|c|c|c|c|}
\hline Hora do dia & $\begin{array}{c}\text { Frota } \\
\text { disponivel } \\
\left(\boldsymbol{F}_{\boldsymbol{i}}\right)\end{array}$ & $\begin{array}{c}\text { Capacidade } \\
\text { máxima }(\boldsymbol{c})\end{array}$ & $\begin{array}{c}\text { Passageiros } \\
\text { por hora } \\
\left(\boldsymbol{P}_{\boldsymbol{i}}\right)\end{array}$ & $\begin{array}{c}\text { Fator de } \\
\text { carregamento } \\
\left(\boldsymbol{\gamma}_{\boldsymbol{i}}\right)\end{array}$ \\
\hline $17: 00$ & 113 & 202 & 18.087 & 0,8 \\
\hline
\end{tabular}

Tabela 5: Fator de carregamento do horário de pico. Fonte: $\mathrm{O}$ autor.

Para a finalidade deste estudo, foi considerada somente a utilização de ônibus articulados com capacidade de 202 passageiros e com um load factor padrão de 0,8 em todas as horas do dia útil operacional. Aplicando-se na fórmula de Ceder (1984) os valores de valores definidos de $c$ e $\gamma$ juntamente com a demanda de passageiros por hora citada na Figura 8, foi possível determinar, por fim, o tamanho da frota de ônibus necessária em cada hora do dia útil operacional, conforme é apresentado na Figura 10. 


\section{BRT TransOeste \\ Frota diária média DU por hora}

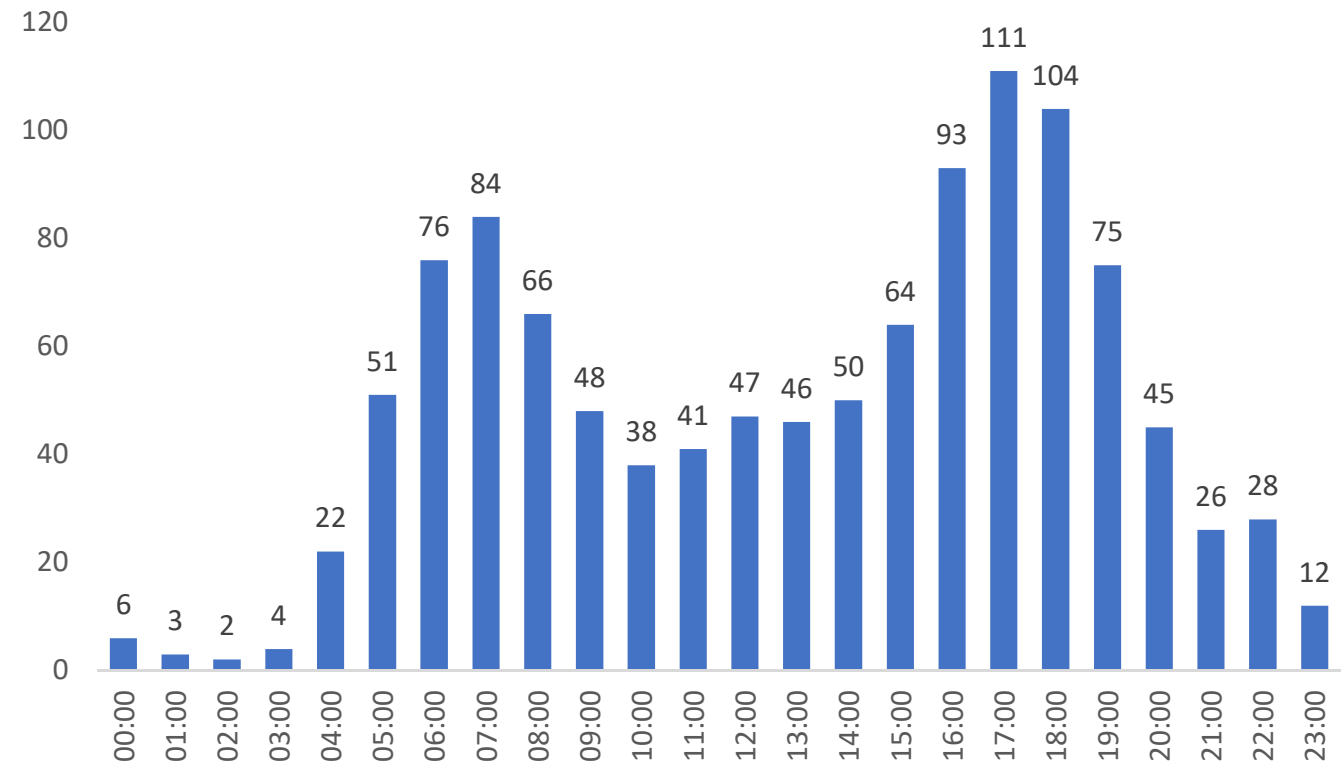

Figura 10: Frota diária média por hora por dia útil. Fonte: O autor

\subsection{Estimativa da quilometragem percorrida diária}

Tendo em vista que a maior parte dos custos e despesas das operações do sistema BRT estão diretamente ligados à rodagem dos veículos, foi necessário definir um parâmetro que medisse o total de quilômetros percorridos pela frota de veículos em cada dia operacional, possibilitando com isso estimar com maior precisão os custos e despesas operacionais no fluxo de caixa do projeto.

A Figura 11 mostra a quilometragem percorrida pela frota de ônibus do corredor BRT TransOeste ao longo de cada hora do dia útil operacional, com base no estudo de oferta do Consórcio Operacional do BRT. Os dados foram apresentados de forma cumulativa, com o somatório dos quilômetros percorridos pela frota de veículos operacional ao longo de 24 horas de operação. 
BRT TransOeste - Quilometragem média percorrida DU

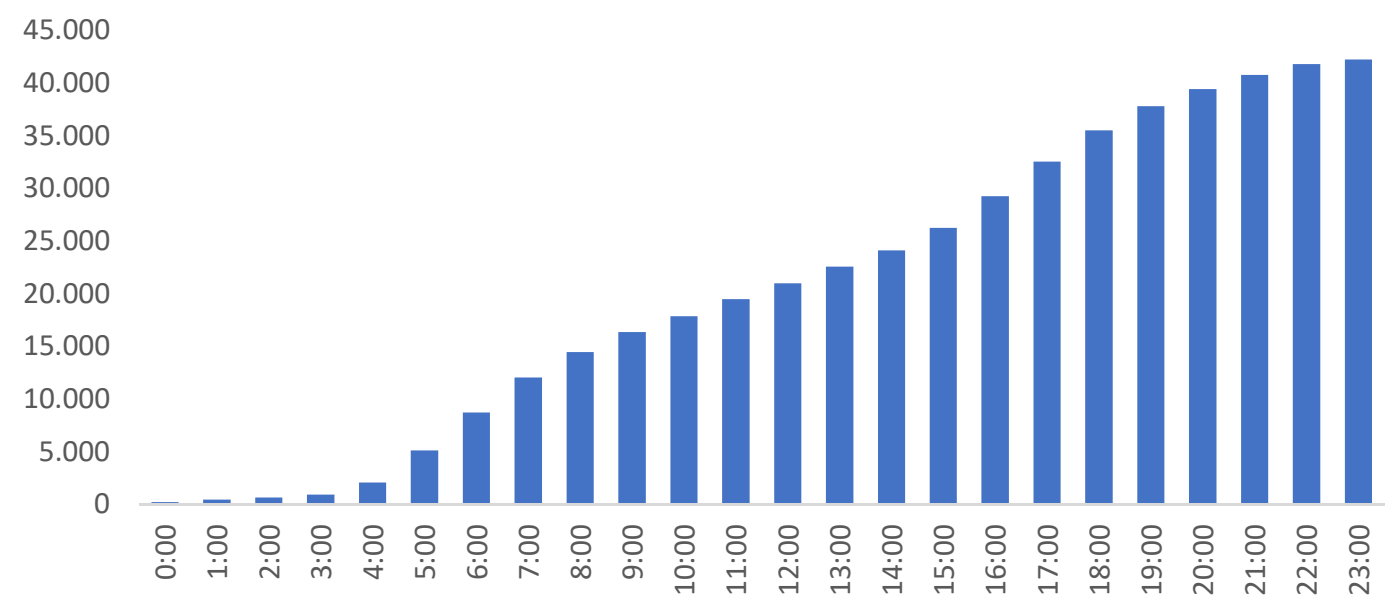

Figura 11: Quilometragem média percorrida por dia útil no corredor BRT TransOeste. Fonte: Base de dados disponibilizada pelo Consórcio Operacional BRT Rio.

De acordo com os dados apresentados na Figura 11, a frota de veículos do corredor BRT TransOeste percorre um total aproximado de 42.254,5 km em cada dia útil operacional.

Para determinar o parâmetro da quilometragem total percorrida, foi feita a análise conjunta de duas variáveis: o tamanho da frota de veículos e a média de quilômetros percorridos por veículo - ou seja, a velocidade média, medida em quilômetros por hora $(\mathrm{km} / \mathrm{h})$ - ao longo de cada hora do dia útil operacional. $A$ Figura 12 mostra a relação entre essas duas variáveis.

BRT TransOeste

Quilometragem média por hora x frota por hora DU

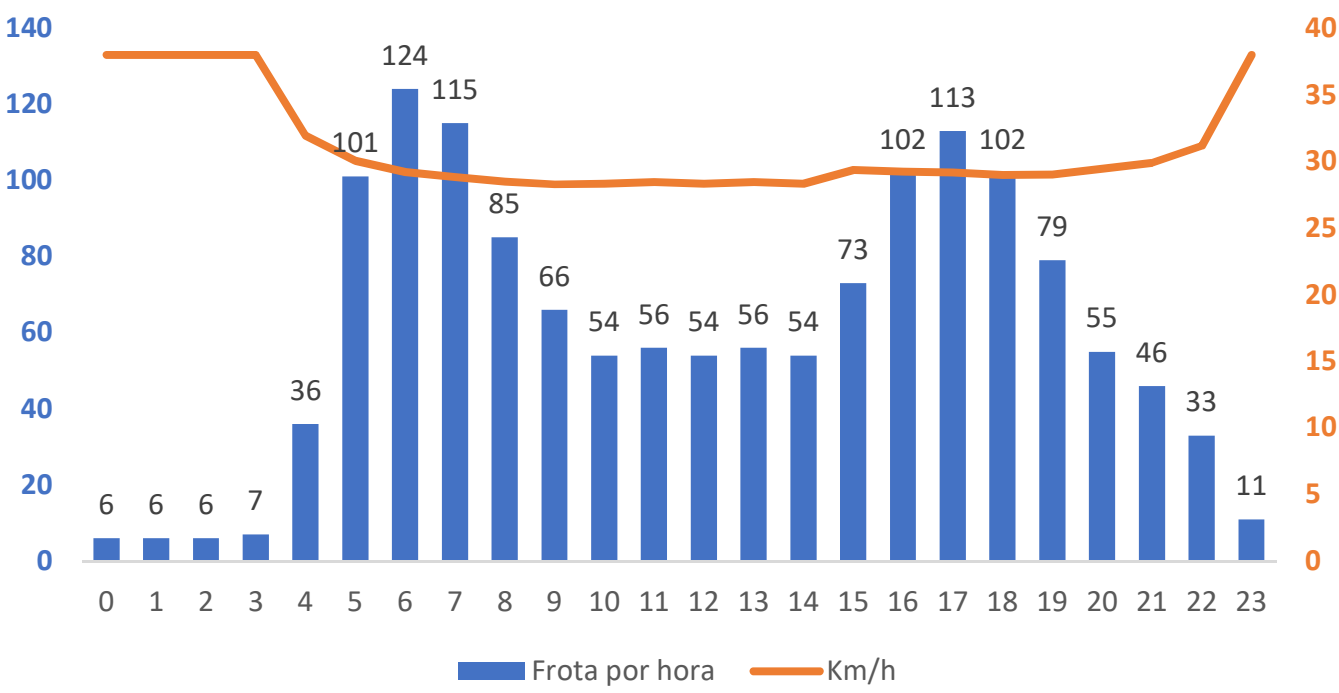

Figura 12: Quilometragem média percorrida por hora x Frota disponível por hora. Fonte: Base de dados disponibilizada pelo Consórcio Operacional BRT Rio. 
$\mathrm{Na}$ análise dos dados da Figura 12, foi possível estabelecer uma relação entre o tamanho da frota e a quilometragem percorrida por hora, dado que o resultado do somatório acumulado do produto entre essas duas variáveis é exatamente igual ao da quilometragem total percorrida pela frota definido na Figura 11 - ou seja, 42.254,5 km.

Como já mencionado na seção anterior, para a finalidade deste estudo, foi considerada somente a utilização de ônibus articulados do serviço troncal. Visto que os dados descritos na Figura 12 abrangem informações tanto a frota de ônibus das linhas de serviço troncais como as linhas alimentadoras, que possuem características e capacidades distintas, optou-se por não levar estes dados em consideração para determinar o parâmetro de quilometragem diária percorrida; assim, o parâmetro da quilometragem total percorrida foi determinado com base no tamanho estimado de frota por dia operacional definido na seção anterior e descrito na Figura 10.

Analisando os dados da Figura 12, foi possível observar que a quilometragem média percorrida pela frota de veículos varia entre 29 e $38 \mathrm{~km} / \mathrm{h}$ em cada dia operacional. Para a finalidade deste estudo, foi assumida uma velocidade média constante de $30 \mathrm{~km} / \mathrm{h}$ para toda a frota, em todas as horas do dia útil operacional. A Figura 13 descreve a relação entre o tamanho estimado de frota por hora e a quilometragem percorrida média por hora constante.

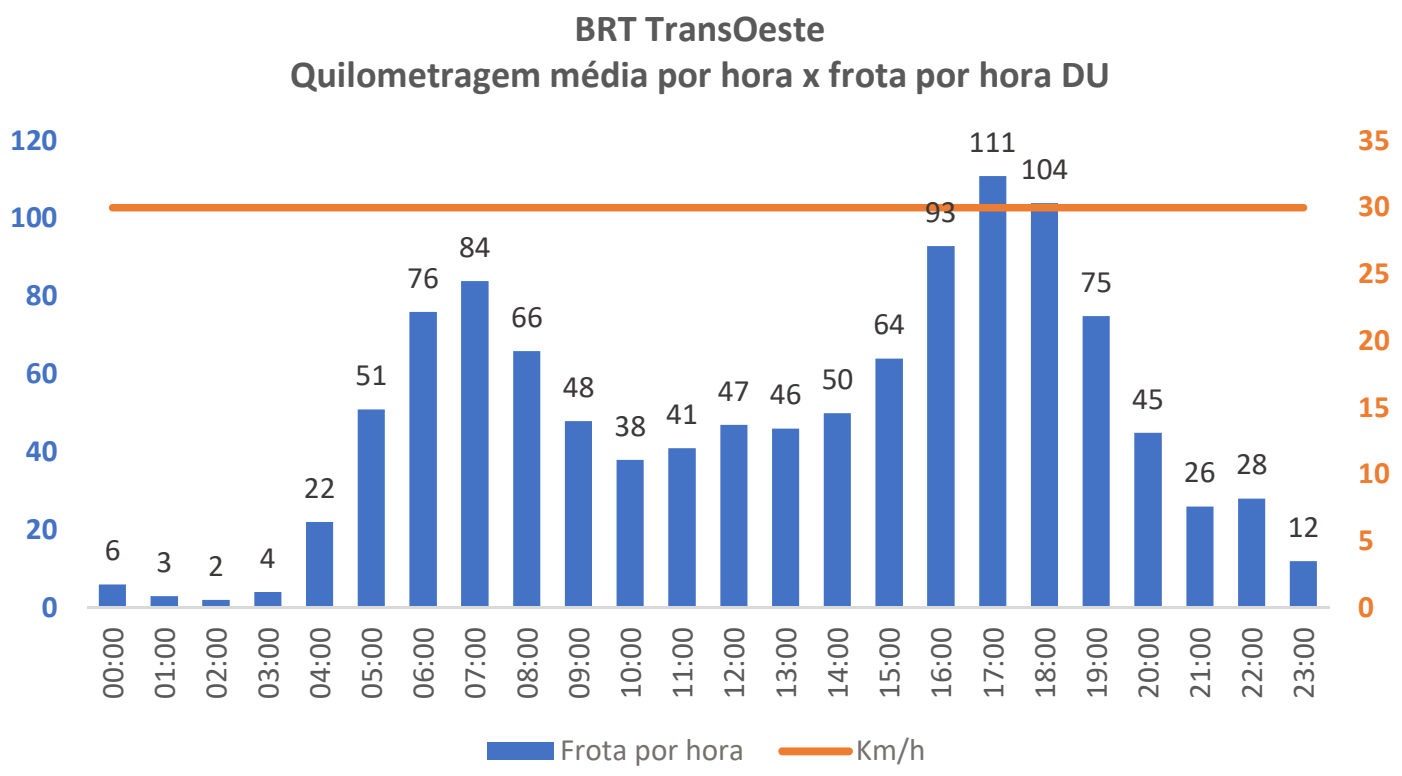

Figura 13: Quilometragem média percorrida por hora x frota média por hora em dias úteis. Fonte: o Autor. 
Ao aplicar-se a mesma regra utilizada para calcular a quilometragem média percorrida com os dados da Figura 12 aos dados mostrados na Figura 13, foi possível definir, por fim, o parâmetro da quilometragem média diária percorrida pela frota adotado no projeto, totalizando $34.260 \mathrm{~km}$ em cada dia operacional útil. A memória de cálculo do parâmetro de quilometragem total percorrida está detalhado na Tabela 6:

\begin{tabular}{|c|c|c|c|c|c|}
\hline $\begin{array}{c}\text { Hora do } \\
\text { dia }\end{array}$ & $\begin{array}{c}\text { Passageiros } \\
\text { transportados } \\
\text { por hora }\end{array}$ & $\begin{array}{c}\text { Frota por } \\
\text { hora }\end{array}$ & $\mathbf{K m} / \mathbf{h}$ & $\begin{array}{c}\text { Quilometragem } \\
\text { total por hora }\end{array}$ & $\begin{array}{c}\text { Quilometragem } \\
\text { total por hora } \\
\text { acumulada }\end{array}$ \\
\hline $00: 00$ & 1.090 & 6 & 30,0 & 180 & 180 \\
\hline $01: 00$ & 564 & 3 & 30,0 & 90 & 270 \\
\hline $02: 00$ & 388 & 2 & 30,0 & 60 & 330 \\
\hline $03: 00$ & 804 & 4 & 30,0 & 120 & 450 \\
\hline $04: 00$ & 3.602 & 22 & 30,0 & 660 & 1.110 \\
\hline $05: 00$ & 8.246 & 51 & 30,0 & 1.530 & 2.640 \\
\hline $06: 00$ & 12.311 & 76 & 30,0 & 2.280 & 4.920 \\
\hline $07: 00$ & 13.733 & 84 & 30,0 & 2.520 & 7.440 \\
\hline $08: 00$ & 10.684 & 66 & 30,0 & 1.980 & 9.420 \\
\hline $09: 00$ & 7.803 & 48 & 30,0 & 1.440 & 10.860 \\
\hline $10: 00$ & 6.294 & 38 & 30,0 & 1.140 & 12.000 \\
\hline $11: 00$ & 6.643 & 41 & 30,0 & 1.230 & 13.230 \\
\hline $12: 00$ & 7.680 & 47 & 30,0 & 1.410 & 14.640 \\
\hline $13: 00$ & 7.551 & 46 & 30,0 & 1.380 & 16.020 \\
\hline $14: 00$ & 8.084 & 50 & 30,0 & 1.500 & 17.520 \\
\hline $15: 00$ & 10.363 & 64 & 30,0 & 1.920 & 19.440 \\
\hline $16: 00$ & 15.053 & 93 & 30,0 & 2.790 & 22.230 \\
\hline $17: 00$ & 18.087 & 111 & 30,0 & 3.330 & 25.560 \\
\hline $18: 00$ & 16.949 & 104 & 30,0 & 3.120 & 28.680 \\
\hline $19: 00$ & 12.158 & 75 & 30,0 & 2.250 & 30.930 \\
\hline $20: 00$ & 7.297 & 45 & 30,0 & 1.350 & 32.280 \\
\hline $21: 00$ & 4.294 & 26 & 30,0 & 780 & 33.060 \\
\hline $22: 00$ & 4.592 & 28 & 30,0 & 840 & 33.900 \\
\hline $23: 00$ & 1.969 & 12 & 30,0 & 360 & 34.260 \\
\hline & & & & & \\
\hline
\end{tabular}

Tabela 6: Quilometragem média diária percorrida por dia útil. Fonte: o autor.

A Equação 7 representa a fórmula utilizada para calcular o parâmetro da quilometragem total percorrida em cada dia operacional do corredor BRT:

$$
\text { TotKm }=\sum_{i=1}^{24} K m H * \frac{P_{i}}{\gamma * c}=\sum_{i=1}^{24} K m H * F_{i}
$$

Onde $\mathrm{KmH}$ representa a velocidade média constante percorrida por cada veículo, $P_{i}$ é a demanda de passageiros transportados na hora $i, \gamma$ é o load factor, $c$ é a capacidade de passageiros transportados por veículo, e $F_{i}$ é o tamanho da frota de veículos na hora $i$. Em suma, a Equação 7 consiste basicamente em uma adaptação do valor $F_{i}$ determinado pela fórmula de Ceder (1984) descrita na Equação 6, cujo produto por $K m H$ é somado ao longo das 24 horas $i$ do dia útil operacional. 


\subsection{Fluxo de caixa do projeto}

Após terem sido definidos os parâmetros utilizados para estimar as receitas e custos variáveis do projeto - a demanda diária média por dia útil, a demanda de pico por dia útil, o tamanho da frota de veículos em cada hora do dia, o fator de carregamento e a quilometragem diária acumulada percorrida por dia útil -, foi possível avançar para a etapa de modelagem do fluxo de caixa do projeto do corredor BRT TransOeste.

O fluxo de caixa do projeto do BRT TransOeste foi montado com base na metodologia descrita no Relatório P42 da Secretaria Municipal de Transportes do Rio de Janeiro (SMTR, 2018). Esta metodologia foi desenvolvida por uma empresa de auditoria contratada pela Prefeitura do Rio com o objetivo de fazer a avaliação e a projeção dos fluxos de caixas individuais e consolidados dos consórcios responsáveis pelo serviço de transporte público de ônibus do município do Rio de Janeiro - entre eles, o próprio sistema BRT. Diferentemente da metodologia empregada no Relatório P42 da SMTR, que mesclou as informações relativas ao sistema BRT às informações dos serviços de ônibus convencionais, a metodologia desenvolvida neste estudo foi aplicada exclusivamente ao caso do corredor BRT TransOeste. 
O modelo do fluxo de caixa utilizado no modelo está descrito na Tabela 7:

\begin{tabular}{|ll|}
\hline Descrição do Fluxo de Caixa do Modelo & \\
\hline Receita bruta & Receita tarifária \\
(-) Deduções da receita bruta & Receita não-tarifária \\
& PIS \\
& COFINS \\
& ISS \\
(-) Taxa de administração do bilhete eletrônico & INSS \\
(3\% da receita tarifária proveniente de bilhetes eletrônicos) & \\
Receita líquida & \\
(-) Despesas operacionais & Mão de obra \\
& Insumos \\
& IPVA e DPVAT \\
Resultado operacional & Garagens e instalações \\
(-) Outras despesas operacionais e administrativas & \\
(-) Despesa de depreciação & \\
Resultado operacional antes do IR e CSLL & \\
(-) IR & \\
(-) CSLL & \\
Resultado operacional líquido & \\
(-) Investimento & \\
(+) Depreciação & \\
Fluxo de caixa do ativo & \\
\hline
\end{tabular}

Tabela 7: Fluxo de caixa do modelo. Fonte: Relatório P42 da SMTR (2018).

\subsubsection{Cálculo das receitas}

\subsubsection{Receita tarifária}

Segundo a metodologia descrita no Relatório P42 da SMTR (2018), a receita tarifária consiste na receita proveniente da prestação do serviço de transporte de ônibus, e é obtida a partir do produto entre a demanda de usuários pagantes do sistema e as tarifas de ônibus em vigor. $\mathrm{O}$ valor de tarifa utilizado no modelo corresponde ao valor da tarifa integral cobrada para uso do serviço de usuários do sistema BRT vigente no ano de 2019 , ou seja, $R \$ 4,05$. Como a avaliação do projeto foi realizada em valores nominais, ou seja, sem considerar a incidência de inflação, foi mantida a mesma tarifa em todos os anos do projeto

\subsubsection{Demanda de usuários transportados}

Para estimar a demanda de usuários pagantes, foram assumidas algumas premissas relativas à demanda diária de passageiros. O Relatório P42 da SMTR (2018) distingue três categorias de usuários do sistema de transporte público por ônibus, a saber: 
- Demanda total de usuários transportados, identificada como TOTPAX

- Demanda de usuários de gratuidades, identificada como TOTGRAT

- Demanda de usuários de integração, identificada como BUCINT

A demanda de usuários de gratuidade contempla idosos maiores de 65 anos, estudantes uniformizados da rede pública de ensino de primeiro e segundo graus em período letivo e pessoas com necessidades especiais (PNE).

Segundo o Relatório P42 da SMTR (2018), o Relatório Diário de Operações (RDO) - onde consta a demanda de usuários transportados diariamente nas linhas de ônibus da cidade - registra dupla contagem de usuários de integração, isto é, a cada reentrada do usuário no sistema é feita uma nova contagem, contemplando todas as integrações dos mesmos usuários.

Desta forma, para se alcançar a demanda total de usuários pagantes, devese subtrair o total de usuários de integração da demanda total de usuários, assim como a de usuários de gratuidade. Portanto, a demanda de usuários pagantes identificada como TOTSPAG - pode ser representada pela expressão mostrada na Equação 8:

$$
\text { TOTSPAG }=\text { TOTPAX }- \text { TOTGRAT }- \text { BUCINT }
$$

Para o modelo proposto para o sistema BRT TransOeste, o total de usuários de gratuidades equivaleu a proporção de usuários de gratuidade calculada na seção 5.1 .2 , de $6,7 \%$ da demanda total de passageiros.

Adicionalmente, tendo em vista o impacto considerável que o índice de evasão de passageiros representa no montante de receita tarifária, optou-se por incluir mais uma variável no cálculo da demanda de usuários pagantes expresso na Equação 6. Dessa forma, além dos parâmetros já citados, foi subtraído o índice de evasão de passageiros, da ordem de 9,5\% da demanda diária total de usuários. A variável em questão foi denominada como EVPAX.

Para estimar a demanda de usuários de integração, foi analisada a proporção de usuários de integração observada no relatório "Indicador de Demanda por Consórcio" (Tabela 8).

Os dados apresentados referem-se à quantidade de passageiros transportados pelo Consórcio Operacional do BRT Rio no período que compreende os meses de janeiro a agosto de 2019. Os dados citados foram extraídos do site da Prefeitura Municipal do Rio de Janeiro. 


\begin{tabular}{|c|c|c|}
\hline Descrição & Código & Quantidade \\
\hline Viagens realizadas & - & 1.115 .390 \\
\hline Total de gratuidades & TOTGRAT ou TOTPASGRAT & 14.075 .563 \\
\hline BUC $1^{\circ}$ perna & $B U C$ & 20.506 .401 \\
\hline BUC $2^{\circ}$ perna integração & BUCINT & 22.634 .982 \\
\hline BUC SuperVia $1^{\circ}$ perna & $B U C S$ & 1.494 .841 \\
\hline BUC SuperVia $2^{\circ}$ perna integração & BUCSINT & 2.034 .847 \\
\hline Vale-transporte & BUTMET ou BUTVT & 36.272 .102 \\
\hline Pagamentos em espécie & TOTPASPAG & 4.555 .053 \\
\hline Total de pagantes & TOTSPAG & 87.498 .226 \\
\hline Total de passageiros transportados & TOTPAX & 101.573 .789 \\
\hline
\end{tabular}

Tabela 8: Dados de passageiros transportados no Consórcio Operacional do BRT entre janeiro e agosto de 2019. Fonte: Site da Prefeitura do Rio.

O Relatório P42 da SMTR (2018) define como usuários de integração os usuários que realizaram o $2^{\circ}$ trecho de integrações do Bilhete Único Carioca (BUC) entre ônibus (BUCINT). Analisando a Tabela 8, foi constatado um total de 22.634.982 usuários que se enquadram nessa categoria. A razão de usuários de integração sobre a demanda total de usuários transportados do período foi de $22,3 \%$. Este foi o parâmetro adotado para estimar a proporção de usuários de integração do modelo. Reorganizando a Equação 6 com as informações citadas, a demanda de usuários pagantes pôde ser obtida conforme a Equação 9:

$$
\text { TOTSPAG }=\text { TOTPAX - TOTGRAT }- \text { BUCINT }- \text { EVPAX }
$$

onde:

$$
\begin{aligned}
& \text { TOTGRAT }=0,067 * \text { TOTPAX } \\
& \text { EVPAX }=0,095 * \text { TOTPAX } \\
& \text { BUCINT }=0,223 * \text { TOTPAX }
\end{aligned}
$$

No modelo, a variável TOTSPAG equivaleu a demanda diária $\operatorname{DemDia}_{t}$ multiplicada pelo total de dias operacionais do ano ( $D O p)$.

Reorganizando a Equação 9 foi possível chegar à equação utilizada para estimar o total de passageiros pagantes transportados ao longo do ano:

$$
\begin{aligned}
& \text { TOTSPAG }=\text { DemDia }_{t} * \text { DOp } \times(1-0,385) \\
& \text { TOTSPAG }=0,615 * \text { DemDia }_{t} * \text { DOp }
\end{aligned}
$$

onde DemDia $a_{t}$ é a demanda diária média de passageiros por dia útil e DOp é o total de dias operacionais em um ano. Para a avaliação do projeto, foi considerado um total de 300 dias operacionais por ano. Segundo Hsu (2012), o valor de 300 
dias operacionais por ano é um padrão utilizado para avaliação de projetos desta natureza.

Adicionando à Equação 10 a informação da tarifa, foi obtida a fórmula efetivamente usada no modelo para o cálculo da receita tarifária diária.

$$
\text { RecTarif }=\text { TOTSPAG } * \text { TarifDia }
$$

\subsection{Usuários pagantes de bilhetagem eletrônica}

Após ter sido definida a receita tarifária, o próximo passo consistiu em segmentar a demanda de usuários pagantes pela forma de pagamento efetuado - bilhetagem eletrônica ou pagamentos em espécie. Esta etapa foi necessária para calcular o percentual de repasse para a empresa administradora de bilhetes eletrônicos. Na metodologia do Relatório P42 da SMTR (2018), é calculado um repasse de $3 \%$ incidente sobre a receita tarifária proveniente de pagamentos em bilhetagem eletrônica.

Para estimar a receita tarifária de bilhetagem eletrônica, foram analisados os dados da demanda total de usuários pagantes (TOTSPAG) e usuários de pagamento em espécie (TOTPASPAG) descritos na Tabela 8. Foi definido um percentual de $5,2 \%$ para os pagamentos realizados em espécie com base nos dados descritos na Tabela 8. Dessa forma, foi possível estimar a demanda de usuários pagantes de bilhetagem eletrônica como a diferença entre o total de pagantes e o total de pagantes em espécie, ou seja, $94,8 \%$ dos usuários pagantes.

\subsubsection{Receita não-tarifária}

O Relatório P42 da SMTR (2018) descreveu alguns meios para a obtenção de receitas não-tarifárias: receitas de propaganda em veículos do tipo bus door, aluguel de espaço comercial em estações BRT, publicidade do tipo bus TV, venda de sucata de ônibus, revenda de ônibus, entre outras.

Para a finalidade do modelo, a receita não-tarifária foi dividida em duas categorias: receitas de revenda de ônibus e as demais receitas não-tarifárias. Para calcular a receita obtida pela revenda de veículos, foi utilizada a metodologia descrita no Relatório P42 da SMTR, que assumiu o valor residual de revenda como uma porcentagem sobre o valor de mercado de um ônibus articulado BRT novo. O Relatório utilizou uma porcentagem de $5 \%$ para obter o valor residual de revenda. No modelo, essa receita foi obtida no término da vida útil dos ônibus, ou seja, após a depreciação integral deles. 
Para obter o valor das demais receitas não-tarifárias, foi considerada a proporção de 5\% sobre a receita tarifária utilizada por Brandão et al (2012).

\subsubsection{Deduções da receita bruta}

Tendo obtido a receita bruta proveniente das tarifas de usuários pagantes e as receitas de natureza não-tarifária, o próximo passo consistiu no cálculo da receita líquida do projeto. A receita líquida foi obtida após a dedução dos tributos incidentes sobre a receita bruta e do repasse para a administradora dos bilhetes eletrônicos citado na seção 5.4.1.1.2.

Foram utilizadas as alíquotas de tributos descritas no Relatório P42. Foram identificados no relatório quatro tributos incidentes sobre a receita bruta: PIS, COFINS, ISS e INSS. Cada um destes tributos possuem uma alíquota distinta para cada categoria de receita, descritos na Tabela 9:

\begin{tabular}{|c|c|c|}
\hline Imposto & $\begin{array}{c}\text { Receitas } \\
\text { tarifárias }\end{array}$ & $\begin{array}{c}\text { Receitas não- } \\
\text { tarifárias }\end{array}$ \\
\hline PIS & $0,00 \%$ & $1,65 \%$ \\
\hline COFINS & $0,00 \%$ & $7,60 \%$ \\
\hline ISS & $0,01 \%$ & $5,00 \%$ \\
\hline INSS & $3,00 \%$ & $3,00 \%$ \\
\hline
\end{tabular}

Tabela 9: Tributos incidentes sobre a receita bruta. Fonte: Relatório P42 da SMTR (2018).

\subsubsection{Custos operacionais}

Após ter sido definida a metodologia para estimar a receita líquida, foram calculados os custos e despesas relacionados à operação, administração e manutenção do sistema BRT. O Relatório P42 da SMTR (2018) agrupa os custos e despesas operacionais do serviço de ônibus em cinco grandes contas: (1) mão de obra e encargos, (2) insumos; (3) garagens e instalações, (4) IPVA e DPVAT e (5) outros custos e despesas operacionais. As seções 5.4.2.1 a 5.4.2.5 descrevem a metodologia utilizada para calcular cada uma delas.

\subsubsection{Mão de obra e encargos}

\subsubsection{Pessoal de operação}

Para estimar os custos relacionados ao pessoal de operação, foram consideradas duas variáveis: o fator de utilização e o salário de cada função. Segundo o Relatório P42 da SMTR (2018) , o fator de utilização é um parâmetro que representa o total de funcionários necessário para cumprir uma jornada de 
trabalho padrão da categoria, que no Rio de Janeiro corresponde a sete horas de trabalho por dia com uma folga semanal, mais um adicional para cobrir folgas, férias e faltas.

A Tabela 10 relaciona as funções e seus respectivos fatores de utilização e salários. Os valores dos salários correspondem aos pisos salariais acordados pelo Sindicato dos Rodoviários do Rio de Janeiro (SINTRATURB-RJ) em setembro de 2019. Diferentemente do serviço de ônibus convencionais, a função de cobrador não se aplica ao caso do BRT, pois a cobrança da tarifa é efetuada nas bilheterias ou nas roletas das estações.

\begin{tabular}{|c|c|c|}
\hline Função & $\begin{array}{c}\text { Fator de utilização } \\
\text { (funcionário por ônibus) }\end{array}$ & Salário mensal (R\$) \\
\hline Motorista BRT & 1,87 & $3.074,66$ \\
\hline Fiscal & 0,15 & $1.671,17$ \\
\hline Despachante & 0,11 & $2.562,23$ \\
\hline
\end{tabular}

Tabela 10: Pessoal de operações. Fonte: Relatório P42 da SMTR (2018).

Como é possível observar, o cálculo do custo da folha de pagamento do pessoal de operação ocorre em função do tamanho da frota diária de veículos em circulação. Dessa forma, este cálculo pode ser representado pela Equação 12:

$$
\text { SalOp }=\sum_{i=1}^{n} F_{i} * \operatorname{SalM}_{i} * n B R T * 12
$$

Onde $n$ é o total de funções de operação, $F U t_{i}$ é o fator de utilização da função $i, S_{a l M}$ é o salário mensal da função $i$ e $n B R T$ é a frota diária máxima de ônibus BRT em circulação. Multiplicando-se os dados descritos na equação por 12, foi possível chegar ao custo anual dos salários com o pessoal de operação (SalOp).

Além das funções já citadas, existe também a função do bilheteiro, que fica alocado nas estações ao longo do corredor por onde passam os ônibus articulados BRT. Conforme foi descrito no Relatório P42 da SMTR (2018), a estimativa do número de bilheteiros necessários no sistema não possui relação com o tamanho da frota, mas com o número de bilheterias em cada estação do sistema.

O relatório não especificou um método específico para estimar o total de bilheteiros necessários no corredor. Por conta disso, optou-se por estimar esse número com base no valor do salário da função de bilheteiro, do número de estações ao longo do corredor, do número de cabines de bilheteria por estação e do número de turnos de trabalho por dia. 
Como o salário da função de bilheteiro não havia constado no acordo coletivo de 2019 , foi adotado o valor de $\mathrm{R} \$ 1.386,17$, que corresponde ao piso da categoria acordado pela SINTRAURB-RJ em junho de 2018. Foram assumidos dois turnos diários de trabalho por estação.

O corredor BRT TransOeste conta com um total de 67 estações, somando os trechos entre os terminais Jardim Oceânico, Santa Cruz e Campo Grande. Existem três categorias de estações: (1) as estações de módulo único, que comportam até quatro ônibus articulados; (2) as estações com módulo duplo, que comportam até oito ônibus articulados; e (3) as estações terminais. As estações com um módulo contam com uma cabine de bilheteria apenas, enquanto as de dois módulos e os terminais contam com duas cabines de bilheteria.

A Tabela 11 resume as informações das categorias de estações do corredor BRT TransOeste.

\begin{tabular}{|c|c|}
\hline Descrição & Valor \\
\hline Número de estações de módulo único & 57 \\
\hline Número de estações de módulo duplo & 6 \\
\hline Número de estações terminais & 4 \\
\hline Total de estações & $\mathbf{6 7}$ \\
\hline
\end{tabular}

Tabela 11: Categorias de estações do corredor BRT TransOeste. Fonte: Estudo de viabilidade do BRT TransOeste.

Multiplicando-se o somatório do número total de cabines de bilheterias de cada estação pelo número de turnos de trabalho diários, foi estimado um contingente total de 154 bilheteiros no sistema. Ao multiplicar esse total pelo salário mensal, pôde-se obter o custo com os salários da função de bilheteiro.

O Relatório P42 da SMTR especifica ainda a existência de um diretor para gerir cada consórcio. Para o estudo, foi considerado um único diretor para gerir o corredor, com um salário mensal de $\mathrm{R} \$ 25.000,00$, que foi o valor utilizado no relatório.

Portanto, o custo total com os salários do pessoal de operação consistiu no somatório dos salários das funções citadas na Equação 12 com os salários da função de bilheteiro e do diretor, podendo-se chegar finalmente à equação utilizada para calcular o custo total dos salários com o pessoal de operação:

$$
\text { SalOpTot }=\left[\left(\sum_{i=1}^{n} F U t_{i} * \text { SalM }_{i} * B R T\right)+\text { SalBilhet }+ \text { SalDiret }\right] * 12
$$

onde SalBilhet é o salário mensal do bilheteiro e SalDiret é o salário mensal do diretor do consórcio. 


\subsection{Pessoal de manutenção}

Segundo o Relatório P42 da SMTR (2018), os gastos com o pessoal de manutenção correspondem aos gastos com o pessoal envolvido na manutenção dos veículos. O gasto com o pessoal de manutenção foi calculado como um percentual sobre o custo com o pessoal de operação. O relatório assumiu um percentual de $11,52 \%$ incidente sobre o total gasto com o pessoal de operação.

\subsection{Encargos sociais e benefícios}

O Relatório P42 da SMTR (2018) descreve algumas categorias de encargos sociais, tais como: INSS, FGTS, auxílio para acidentes de trabalho, abono de férias, aviso prévio, décimo-terceiro salário, adicional noturno, depósito por rescisão etc. Esses encargos foram calculados como uma porcentagem sobre o custo com o pessoal de operação e manutenção. Somando-se as alíquotas dos encargos incidentes, foi adotado um percentual de 40,16\% sobre o custo com o pessoal de operação e manutenção.

Os benefícios referem-se a gastos com uniformes, vale alimentação e refeição, vale transporte, entre outros benefícios acordados com o sindicato. De forma similar aos encargos sociais, o relatório assume o cálculo dos benefícios como uma porcentagem de $6,49 \%$ sobre o custo com o pessoal de manutenção.

Portanto, a equação utilizada no modelo para estimar o custo total com o pessoal de operação de manutenção, incluindo os encargos sociais e benefícios está resumido na Equação 14:

$$
\text { CTotOM }=1,4665\left\{13,1824\left[\left(\sum_{i=1}^{n} F U t_{i} * \text { SalM }_{i} * \text { BRT }\right)+\text { SalBilhet }+ \text { SalDiret }\right]\right\}
$$

\subsubsection{Insumos}

O Relatório P42 da SMTR (2018) classificou cinco tipos de custos na categoria de insumos: (1) consumo de combustível, (2) consumo de ARLA (reagente químico), (3) lubrificantes, (4) peças e acessórios e (5) material de rodagem. 


\subsection{Combustível}

O custo com combustível foi calculado com base em três parâmetros: o coeficiente de consumo de combustível, o preço do combustível e a quilometragem percorrida. Essa categoria de custo está diretamente relacionada à quilometragem percorrida pelo material rodante.

Os veículos articulados do BRT utilizam como combustível o óleo diesel S10. Segundo o Relatório P42 da SMTR (2018), o coeficiente de consumo de combustível consiste na quantidade de litros de combustível consumidos a cada quilômetro rodado (L/km). No relatório, foi adotado um coeficiente de consumo de $0,7840 \mathrm{~L} / \mathrm{km}$. O preço médio ao consumidor do diesel S10 no município do Rio de Janeiro em dezembro de 2019, segundo consulta realizada no site da Agência Nacional do Petróleo (ANP), foi de R 3,876 por litro.

A partir do produto entre a quilometragem percorrida diária, o coeficiente de consumo de combustível e o preço do combustível, foi possível calcular o custo de consumo de combustível diário. Multiplicando-se o custo diário pelo total de dias operacionais do ano, foi possível calcular o custo anual com consumo de combustível. Esse custo pôde ser representado pela Equação 15:

$$
\text { CTotComb }=3,038784 * \text { TotKm } * \text { DOp }
$$

Onde o coeficiente 3,038784 é o produto entre o coeficiente de consumo de combustível e o preço do combustível, TotKm é a quilometragem total percorrida pelo material rodante em um dia.

\subsection{ARLA}

Segundo o exposto no Relatório P42 da SMTR (2018), o ARLA é um reagente químico à base de ureia, utilizado com a finalidade de reduzir os níveis de emissão de gases poluentes, conforme determinado pelas agências reguladoras competentes. O relatório assumiu o consumo de ARLA como uma proporção de $5 \%$ do consumo de combustível diesel S10 (em litros). Foi adotado o mesmo valor de custo de consumo do ARLA do relatório, de $\mathrm{R} \$ 1,00$ por litro, e foi representado pela Equação 16:

$$
\text { CTotARLA }=0,0392 * \operatorname{TotKm} * \text { DOp }
$$




\subsection{Lubrificantes}

O consumo de lubrificantes foi estimado como um percentual de $2,65 \%$ sobre o custo do consumo de combustível, seguindo a mesma metodologia adotada no Relatório P42 da SMTR (2018). A Equação 17 descreve o cálculo do custo com lubrificantes:

$$
\text { CTotLub }=0,0265 * \text { CtotComb }
$$

\subsection{Peças e acessórios}

A despesa com peças e acessórios, de acordo com a descrição do Relatório P42 da SMTR (2018), se refere à compra de peças de reposição para a manutenção dos veículos da frota. Para estimar o valor das despesas com peças e acessórios, foi considerado um percentual de $0,78 \%$ calculado sobre o valor de mercado da frota total.

A Equação 18 representou o custo com despesas e acessórios:

$$
\text { CTotPAc }=0,0078 * n B R T * V M B R T
$$

Onde VMBRT é o valor de mercado de um veículo BRT novo. Foi adotado o valor de $\mathrm{R} \$ 1.000 .000,00$ como premissa de valor de mercado de um ônibus articulado do tipo BRT novo, com base no valor de mercado informado no Relatório de Intervenção do BRT Rio (2019).

\subsection{Rodagem}

Segundo a metodologia do Relatório P42 da SMTR (2018), os custos de rodagem compreendem os custos relativos à troca de pneus, recapagem, câmara de ar e protetor. Foram adotadas algumas premissas para estimar esses custos: (1) a quantidade de pneus em cada veículo, (2) o número de recapagens por pneu, (3) o preço médio de um pneu novo, (4) o preço médio da recapagem por pneu e (5) a vida útil de cada pneu. A Tabela 12 resume as premissas utilizadas para calcular o custo com rodagem. Todos os valores descritos foram baseados no Relatório P42. 


\begin{tabular}{|c|c|}
\hline Descrição & Valor \\
\hline $\mathrm{N}^{\circ}$ de pneus (ônibus articulado BRT) & 12 \\
\hline $\mathrm{N}^{\circ}$ de recapagens por pneu & 2 \\
\hline Preço médio do pneu & $\mathrm{R} \$ 1.291,56$ \\
\hline Preço da recapagem & $\mathrm{R} \$ 332,80$ \\
\hline Vida útil do pneu & $180.000 \mathrm{~km}$ \\
\hline
\end{tabular}

Tabela 12: Dados para o cálculo do custo de rodagem. Fonte: Relatório P42 da SMTR (2018).

O custo de rodagem anual foi dividido em dois tipos: o custo com a troca de pneus e o custo com a recapagem de pneus. Para estimar o custo de troca de pneus, foram relacionadas duas variáveis: a média de quilômetros percorridos por cada veículo ao longo de um ano (KmBRTano) e a vida útil de cada pneu. Para estimar KmBRTano, foi utilizada a Equação 19:

$$
\text { KmBRTano }=\frac{\text { TotKm } * D O p}{n B R T}
$$

Onde KmBRTano representa média de quilômetros percorridos por veículo ao longo de um ano. Este valor foi obtido pelo produto entre a quilometragem total percorrida diária (TotKm) e o total de dias operacionais do ano $(D O p)$, divididos pela frota média diária $n B R T$. Ao se dividir KmBRTano pelo valor da vida útil do pneu (180.000 km), foi possível estimar a quantidade média de trocas de pneus realizadas por ano.

Por meio do produto entre a quantidade média de trocas de pneus anual e o preço médio de cada pneu (R\$1.291,56), foi possível estimar o custo anual de troca de um pneu. O somatório entre o custo anual de troca de um pneu e o custo de recapagens anuais por pneu $(R \$ 665,60)$ resultou no custo anual total de rodagem para cada pneu. Após se multiplicar este valor pelo número de rodas que contém veículo e pelo tamanho da frota média diária, foi obtido o custo estimado total de rodagem anual (CTotRod), representado pela Equação 20.

$$
\text { CTotRod }=12 * n B R T\left[1.291,56\left(\frac{\text { KmBRTano }}{180.000}\right)+665,60\right]
$$

\subsubsection{Garagens e instalações}

De acordo com a metodologia do Relatório P42 da SMTR (2018), esta categoria compreende custos relacionados ao aluguel dos espaços destinados às oficinas de manutenção e reparos, guarda dos ônibus e almoxarifados. Para estimar os custos com garagens e instalações, foram relacionadas duas variáveis: o tamanho do espaço físico ocupado por cada ônibus articulado BRT (em $\mathrm{m}^{2}$ ) e o 
valor mensal de aluguel do espaço físico $\left(R \$ / m^{2}\right)$. Segundo as informações descritas no relatório, um ônibus articulado BRT possui 18,6 m de comprimento e 2,6 m de largura. O produto entre as dimensões de comprimento em largura resultou em um valor de área total de $48,36 \mathrm{~m}^{2}$ para cada ônibus articulado BRT. O valor mensal do aluguel considerado foi de $\mathrm{R} \$ 11$ por $\mathrm{m}^{2}$ - o mesmo valor utilizado no relatório. Segundo o exposto no Relatório P42, a determinação da área total necessária deve considerar o espaço físico ocupado pelo veículo acrescido de $50 \%$ da área, relativa ao espaço necessário para realizar a manobra dos veículos. Desse modo, o custo total anual com o aluguel de garagens e instalações foram calculados em função do tamanho da frota diária. Esse custo pôde ser representado pela Equação 21:

$$
\text { CTotGI }=1,5 * n B R T * 48,36 * 11 * 12=9575,28 * n B R T
$$

Em resumo, o cálculo do custo total com insumos pôde ser sintetizado na Equação 22:

CTotIns $=$ CTotComb + CTotARLA + CTotLub + CtotPAc + CTotRod + CTotGI

\subsubsection{IPVA e DPVAT}

O Relatório P42 da SMTR (2018) calcula o custo com IPVA como uma alíquota de $2 \%$ sobre o valor de mercado do veículo. Para o valor do DPVAT, o relatório assume uma taxa única de $\mathrm{R} \$ 396,49$ por veículo. Esses foram os valores utilizados no modelo. A Equação 23 resume o cálculo do custo anual com IPVA e DPVAT:

$$
\text { CTotI }=n B R T *(0,02 * V M B R T+396,49)
$$

\subsubsection{Despesas administrativas e outros custos e despesas operacionais}

O Relatório P42 da SMTR (2018) define as despesas administrativas como os gastos não relacionados às operações, constituídos de várias atividades que beneficiam todas as atividades do negócio. 
Os gastos classificados como despesas administrativas estão detalhados abaixo:

- Despesas com utilidades (gás, energia elétrica, água e esgoto)

- Comunicações

- Seguros

- Serviços prestados

- Despesas com conservação de bens e instalações

- Fretes e carretas

- Segurança e Transporte de Valores

- Aluguéis (exceto garagens)

- Despesas com refeições

- Despesas tributárias

- Impostos, taxas e contribuições

- Taxa de licenciamento e administração

- Despesas legais e judiciais

- Indenizações trabalhistas

- Despesas com Pessoal Administrativo

Na metodologia do Relatório P42 da SMTR (2018), foi utilizado um parâmetro fixo de padronização das despesas administrativas dos consórcios, sendo ela calculada como uma proporção de $20 \%$ da receita líquida do projeto (receita bruta tarifária e não tarifária subtraída das deduções e do repasse da administradora de bilhetagem eletrônica). Para o cálculo das despesas administrativas do projeto utilizou a mesma metodologia. Essas despesas foram representadas pela Equação 24:

$$
\text { DespAdm }=0,2 * \text { RecLiq }
$$

\subsubsection{Depreciação}

A depreciação da frota foi calculada com base no método de Cole, seguindo o mesmo critério aplicado no Relatório P42 da SMTR (2018). Neste método, a taxa de depreciação ocorre de forma não-linear e decrescente, com frações maiores nos primeiros períodos de depreciação e menores no final.

Segundo a descrição do Relatório P42 da SMTR, a depreciação pelo método de Cole consiste em dividir o valor total do ativo a ser depreciado em frações tais que o numerador expresse os períodos que faltam para o final da vida útil do bem, 
e o denominador represente o somatório dos períodos de depreciação. Para calcular a depreciação pelo método de Cole, foi tomado como premissa o valor contábil da frota (neste caso, o valor de mercado VMBRT) descontado do seu valor residual ao final de sua vida útil ( $5 \%$ de $V M B R T)$. Portanto, o valor total depreciado de cada veículo corresponde a $95 \%$ do $V M B R T$. Ao fim da vida útil, o valor residual de $5 \%$ foi calculado como receita não-tarifária de revenda. A depreciação foi calculada no período entre o ano seguinte após a aquisição do veículo e o último ano de vida útil - que correspondeu também ao ano de revenda. Para o cálculo do projeto, foi considerada uma vida útil de sete anos para cada veículo articulado BRT, seguindo a estimativa de depreciação da frota descrita no Relatório de Intervenção do BRT Rio (2019).

Dessa forma, o cálculo da depreciação da frota de ônibus BRT pôde ser expresso pela Equação 25:

$$
\operatorname{Dep}_{t}=\sum_{n=1}^{t} n B R T_{n} * 0,95 * V M B R T \times \frac{8-t}{\sum_{m=1}^{7} m}
$$

Os valores de depreciação acumulada anual variaram em função do ano em que os veículos foram adquiridos. Para a finalidade da construção do fluxo de caixa do projeto, foi considerada uma frota inicial composta inteiramente de veículos novos - ou seja, a frota adquirida a partir do ano zero.

\subsubsection{Tributos incidentes sobre o Resultado}

Segundo o Relatório P42 da SMTR (2018), o regime de tributação aplicado às concessionárias do Serviço Público de Transporte Público do município do Rio de Janeiro (SPPO-RJ) é o Lucro Real. As alíquotas incidentes foram descritas na Tabela 13:

\begin{tabular}{|c|c|}
\hline Descrição & Alíquota \\
\hline IRPJ & $15,00 \%$ \\
\hline IRPJ adicional & $10,00 \%$ \\
\hline CSLL & $9,00 \%$ \\
\hline
\end{tabular}

Tabela 13: Tributos incidentes sobre o resultado. Fonte: Relatório P42 da SMTR (2018).

Desse modo, o resultado líquido do projeto consistiu no resultado operacional deduzido dos tributos incidentes sobre o resultado operacional (34\%). 


\subsubsection{Resultado operacional líquido}

Tendo sido definidas todas as premissas e métodos de cálculos das receitas e custos, foi possível chegar ao valor do resultado operacional líquido do modelo, representado pela Equação 26:

$$
\begin{aligned}
& \text { ResLiq }=[\text { RecTarif } *(1-0,00301)-(\text { TOTSPAG } * 0,948 * \text { TarifDia }) \\
& * 0,03+\text { RecNTarif } *(1-0,1725)-\text { CTotOM }- \text { CTotIns } \\
& - \text { CTotI }- \text { DespAdm - Dep } t \text { ]* }(1-0,34)
\end{aligned}
$$

\subsubsection{Investimento}

Para a finalidade da avaliação do projeto do BRT TransOeste, foram consideradas três categorias de investimentos: a aquisição de novos veículos, o redimensionamento das estações e a repavimentação de um trecho crítico do corredor.

O gasto para a aquisição de novos veículos ocorreu em duas situações: (1) renovação da frota, decorrente da substituição do material rodante que chegou ao fim da sua vida útil, e (2) crescimento da demanda diária de passageiros no horário de pico, nos anos em que a frota disponível de ônibus não foi suficiente para comportar a mesma.

O investimento para o redimensionamento das estações tomou como premissa a capacidade máxima estimada de passageiros comportados em cada estação do corredor BRT TransOeste. Para isto, foi utilizada a metodologia de Hidalgo et al (2013), que estima o fluxo máximo de passageiros que uma determinada estação do sistema BRT pode comportar, medida em passageiros por hora. Esse fluxo é calculado com base em alguns parâmetros operacionais do sistema.

Para estimar a capacidade máxima das estações, foi analisado primeiramente o fluxo médio de passageiros transportados ao longo das estações do corredor BRT TransOeste em cada hora do dia com a finalidade de determinar o fluxo máximo de passageiros observado atualmente em cada estação. $O$ anexo da seção 9.3 apresenta graficamente este fluxo médio diário de passageiros em cada estação do corredor TransOeste e em cada hora do dia. Os valores apresentados referem-se aos dias úteis do ano de 2019.

Foi possível verificar nos dados do anexo da seção 9.3 que alguns trechos de estações do corredor BRT TransOeste possuem horários de pico distintos. Enquanto que o trecho das estações localizadas nos bairros da Barra e do Recreio apresentam um fluxo maior de passageiros no período de pico do final da tarde 
(entre 16:00 e 18:00), o trecho de estações entre os bairros de Guaratiba e Santa Cruz apresentam um fluxo maior de passageiros no período de pico da manhã, entre 05:00 e 08:00. Dada esta diferença de fluxo de passageiros nas estações ao longo do dia, foi assumida como referência o fluxo máximo de passageiros observado em cada uma das estações, independente do horário.

A Tabela 14 apresenta o fluxo máximo diário observado de passageiros de cada estação do corredor BRT TransOeste nos dias úteis de 2019.

\begin{tabular}{|c|c|c|c|}
\hline Estação & $\begin{array}{l}\text { Demanda } \\
\text { máxima }\end{array}$ & Estação & $\begin{array}{l}\text { Demanda } \\
\text { máxima }\end{array}$ \\
\hline 01 - Terminal Jardim Oceânico & 4.353 & 24 - Benvindo de Novaes & 149 \\
\hline 02 - Bosque de Marapendi & 1.337 & 25 - Nova Barra & 305 \\
\hline 03 - Paulo Malta Rezende & 204 & 26 - Gilka Machado & 287 \\
\hline 04 - Afrânio Costa & 350 & 27 - Guiomar Novaes & 142 \\
\hline 05 - Riviera & 273 & 28 - Recreio Shopping & 840 \\
\hline 06 - Ricardo Marinho & 513 & 29 - Recanto das Garças & 31 \\
\hline 07 - Parque das Rosas & 776 & 30 - Notre Dame & 104 \\
\hline 08 - Barra Shopping & 766 & 31 - Dom Bosco & 47 \\
\hline 09 - Terminal Alvorada & 1.927 & 32 - Pontal & 214 \\
\hline 10 - Bosque da Barra & 184 & 33 - Ilha de Guaratiba & 199 \\
\hline 11 - Novo Leblon & 359 & 34 - CTEx. & 30 \\
\hline 12 - Américas Park & 337 & 35 - Embrapa & 11 \\
\hline 13 - Santa Mônica Jardins & 288 & 36 - Mato Alto & 2.398 \\
\hline 14 - Riomar & 123 & 37 - Magarça & 1.094 \\
\hline 15 - Golfe Olímpico & 19 & 38 - Pingo D'Água & 1.382 \\
\hline 16 - Interlagos & 191 & 39 - Vendas de Varanda & 74 \\
\hline 17 - Pedra de Itaúna & 220 & 40 - Santa Veridiana & 191 \\
\hline 18 - Pontões / Barra Sul & 133 & 41 - Curral Falso & 763 \\
\hline 19 - Terminal Recreio & 0 & 42 - Cajueiros & 176 \\
\hline 20 - Salvador Allende & 978 & 43 - Gastão Rangel & 225 \\
\hline 21 - Gelson Fonseca & 70 & 44 - General Olímpio & 374 \\
\hline 22 - Guignard & 143 & 45 - Terminal Santa Cruz & 1.762 \\
\hline 23 - Gláucio Gil & 1.124 & & \\
\hline
\end{tabular}

Tabela 14: Demanda máxima por estação em dias úteis.

Fonte: base de dados disponibilizada pelo Consórcio BRT Rio.

Tendo sido definido o fluxo máximo de passageiros observado em cada estação, o passo seguinte consistiu em determinar o fluxo máximo de passageiros estimado em cada estação e comparar estes valores com os dados observados atualmente. Para calcular a capacidade máxima estimada de passageiros por estação, foi adotada a metodologia de Hidalgo et al. (2013), representada pela Equação 27:

$$
C a[\text { Pax } / h]=\sum_{i=1}^{N s p} X_{i} * \frac{3600[\mathrm{seg} / \mathrm{h}]}{T s b[\text { seg } / \mathrm{bus}] *\left(1-\mathrm{Dir}_{i}\right)+\text { To }[\mathrm{seg} / \mathrm{bus}]} * C p[\mathrm{Pax} / \mathrm{bus}]
$$


onde $\mathrm{Ca}[\mathrm{Pax} / \mathrm{h}]$ representa a capacidade estimada de passageiros de uma determinada estação BRT medida em passageiros por segundo por hora, Nsp é o número de sub-paradas que a estação possui, Tsb[seg/bus] é o tempo de embarque/desembarque em segundos, $\left(1-D i r_{i}\right)$ é o percentual de linhas de ônibus que não param na sub-parada (linhas expressas), To[seg/bus] é o intervalo mínimo entre dois ônibus consecutivos, em segundos, e $C p[\mathrm{Pax} / \mathrm{bus}]$ corresponde ao número máximo de passageiros de cada ônibus, e $X_{i}$ é o nível de saturação aceitável. Para a finalidade do cálculo do projeto, $X_{i}$ equivale ao fator de carregamento $\gamma$ definido na seção 5.2. Foi assumido o mesmo fator de carregamento para todas as estações do corredor, no valor de 0,8. A sub-parada consiste no número de módulos que contém cada estação.

Para definir o parâmetro $\left(1-D i r_{i}\right)$ da proporção de linhas de ônibus que não param nas sub-paradas de cada estação foram analisados os serviços de ônibus que circulam no corredor BRT TransOeste, as estações atendidas por elas e o tipo de serviço que oferecem em cada estação - expresso ou parador. O Anexo da seção 9.4 mostra os serviços de ônibus que atendem o corredor BRT TransOeste.

Foram assumidos valores distintos para o tempo de embarque/desembarque de passageiros $T s b[\mathrm{seg} / \mathrm{bus}]$ de acordo com o tipo de estação. Para os terminais do Jardim Oceânico e da Alvorada, onde os ônibus permanecem por um tempo de embarque e desembarque maior, foi considerado um período de 240 segundos; para as demais estações do corredor, foi considerado um período de 20 segundos. No caso da estação terminal Santa Cruz, foi considerado um período de embarque/desembarque de 60 segundos, visto que, apesar de ser uma estação terminal, ela possui uma configuração estrutural menor que as demais estações terminais.

O intervalo mínimo entre a saída e a chegada dos ônibus $\mathrm{To}[\mathrm{seg} / \mathrm{bus}]$ considerado para as estações terminais do Jardim Oceânico e Alvorada foi de 240 segundos e de 480 segundos para as demais estações do corredor. O valor de $X_{i}$ correspondeu ao número de módulos de embarque/desembarque que contém cada estação. Para as estações terminais Jardim Oceânico e Alvorada foram consideradas 6 sub-paradas; para a estação terminal Santa Cruz, 3 sub-paradas; para as demais estações, o número de sub-paradas equivaleu ao número de módulos de cada uma. A capacidade máxima de passageiros correspondeu ao valor de $c$ da Tabela 5, ou seja, 202 passageiros por veículo. 
Com isso, foi possível calcular a capacidade máxima estimar de passageiros de cada estação. A Tabela 15 mostra a capacidade máxima estimada em cada estação do corredor BRT TransOeste:

\begin{tabular}{|c|c|c|c|}
\hline Estação & $\begin{array}{c}\text { Capacidade } \\
\text { máxima }\end{array}$ & Estação & $\begin{array}{c}\text { Capacidade } \\
\text { máxima }\end{array}$ \\
\hline 01 - Jardim Oceânico & 7.272 & 24 - Benvindo de Novaes & 1.206 \\
\hline 02 - Bosque de Marapendi & 2.368 & 25 - Nova Barra & 1.206 \\
\hline 03 - Paulo Malta Rezende & 1.198 & 26 - Gilka Machado & 1.206 \\
\hline 04 - Afrânio Costa & 1.191 & 27 - Guiomar Novais & 1.201 \\
\hline 05 - Riviera & 1.198 & 28 - Recreio Shopping & 2.327 \\
\hline 06 - Ricardo Marinho & 1.191 & 29 - Recanto das Garças & 1.212 \\
\hline 07 - Parque das Rosas & 1.191 & 30 - Notre Dame & 1.212 \\
\hline 08 - Barra Shopping & 2.381 & 31 - Dom Bosco & 1.212 \\
\hline 09 - Terminal Alvorada & 7.272 & 32 - Pontal & 1.198 \\
\hline 10 - Bosque da Barra & 1.205 & 33 - Ilha de Guaratiba & 1.191 \\
\hline 11 - Novo Leblon & 1.198 & 34 - Cetex & 1.198 \\
\hline 12 - Américas Park & 1.205 & 35 - Embrapa & 1.205 \\
\hline 13 - Santa Mônica Jardins & 1.205 & 36 - Mato Alto & 2.340 \\
\hline 14 - Riomar & 1.198 & 37 - Magarça & 1.173 \\
\hline 15 - Golfe Olímpico & 1.198 & 38 - Pingo D'Água & 1.164 \\
\hline 16 - Interlagos & 1.205 & 39 - Vendas de Varanda & 1.179 \\
\hline 17 - Pedra de Itaúna & 1.205 & 40 - Santa Veridiana & 1.179 \\
\hline 18 - Pontões/ Barrasul & 1.198 & 41 - Curral Falso & 1.164 \\
\hline 19 - Terminal Recreio & 1.198 & 42 - Cajueiros & 1.179 \\
\hline 20 - Salvador Allende & 2.337 & 43 - Gastão Rangel & 1.164 \\
\hline 21 - Gelson Fonseca & 1.206 & 44 - General Olimpio & 1.179 \\
\hline 22 - Guignard & 1.206 & 45 - Terminal Santa Cruz & 3.232 \\
\hline 23 - Gláucio Gil & 1.206 & & \\
\hline
\end{tabular}

Tabela 15: Capacidade máxima estimada pelo método de Hidalgo et al (2013). Fonte: base de dados disponibilizada pelo Consórcio BRT Rio.

Por meio da comparação entre o fluxo médio de passageiros observado em cada estação e o fluxo médio de passageiros estimado, foi possível verificar a necessidade de redimensionamento da capacidade das estações, de modo que essa categoria de investimentos se aplicou somente nos casos em que o fluxo de demanda de passageiros máximo observado em cada estação foi superior a capacidade estimada de em cada uma delas. O redimensionamento consistiu na ampliação da capacidade máxima de passageiros por meio da construção de um módulo adicional nessas estações onde foi notado um excedente de fluxo de passageiros. O montante de investimento considerado para a construção de cada módulo adicional foi de $\mathrm{R} \$ 850.000$, com base no estudo realizado pela Logit (2014) no Plano de Mobilidade Sustentável da cidade de Florianópolis.

Devido ao fato de não ter havido contagem de passageiros no trecho desativado de estações até o terminal Campo Grande na série histórica do ano de 2019 nem informações de linhas de ônibus circulando regularmente neste trecho até o período de conclusão deste estudo, não foi possível calcular o fluxo estimado 
de passageiros das estações contidas neste trecho do corredor BRT TransOeste, e com isto, não foi considerada a análise do redimensionamento destas estações.

O investimento em repavimentação foi incluído no fluxo de caixa do projeto em atenção a um ponto crítico citado no relatório de intervenção referente à necessidade de reconstrução de um trecho de $15,5 \mathrm{~km}$ do corredor TransOeste entre as estações Recreio Shopping e Pontal e entre as estações llha de Guaratiba e Pingo D'Água. $O$ valor do investimento estimado para a repavimentação desse trecho foi de $\mathrm{R} \$ 3,5$ milhões por km construído, também com base no estudo realizado pela Logit (2014) chegando a um montante total estimado de $\mathrm{R} \$ 54,25$ milhões de investimento para a repavimentação do trecho citado. No fluxo de caixa do projeto, foi considerada a realização integral deste investimento no primeiro ano de operação.

Tendo obtido o resultado operacional líquido do projeto, a etapa seguinte consistiu na soma do valor de depreciação e na subtração dos investimentos realizados. O valor resultante desta operação foi o fluxo de caixa do projeto. A Equação 28 resume o valor do fluxo de caixa do projeto utilizado no modelo:

$$
F C_{-} B R T_{t}=\operatorname{ResLiq}+\operatorname{Dep}_{t}+C A P E X_{-} B R T_{t}
$$

onde o valor $F C_{-} B R T_{t}$ corresponde ao fluxo de caixa do ativo no ano $t$. $C A P E X_{-} B R T_{t}$ é o investimento necessário em veículos BRT novos no ano $t$.

\subsection{Análise do projeto pelo método das Opções Reais}

Definida a estrutura do fluxo de caixa do projeto, o próximo passo consistiu na avaliação do projeto pelo método das Opções Reais. Conforme mencionado na seção 5.1.3, a variável de incerteza adotada no modelo de Opções Reais foi a demanda média diária de passageiros no horário de pico. Dado que a variação dos valores de receitas e custos associados ao projeto estão atrelados à variação da demanda de passageiros no horário de pico, foi possível expressar o valor do fluxo de caixa projeto $F C_{-} B R T_{t}$ como uma função da demanda de pico diária $(P)$ conforme a Equação 29:

$$
F C_{-} B R T_{t}=f(P)
$$

A demanda de pico foi modelada como um processo de difusão que segue o movimento geométrico browniano na forma $d P=\mu P d t+\sigma P d z$, onde $\sigma$ é a volatilidade anual de $12 \%$ estimada na seção $5.1 .1, \mu$ é a taxa de crescimento anual esperada da demanda de passageiros, e $d z=\varepsilon \sqrt{d t} \varepsilon \approx N(0,1)$ é o 
incremento de Wiener padrão. A taxa de crescimento anual assumida no modelo foi de $1 \%$ ao ano, correspondente à taxa de crescimento anual de passageiros utilizada na metodologia do Relatório P42.

\subsubsection{Avaliação do projeto pelo método do FCD}

O projeto do corredor BRT TransOeste foi avaliado como uma concessão exclusiva, separada dos demais corredores. Para a avaliação do valor do projeto atual, foi definido um período de treze anos, que corresponde ao período remanescente de concessão do consórcio operacional do BRT do Rio no ano de 2019.

A avaliação do projeto estático - ou seja, sem a variação estocástica da demanda de pico - pelo método do fluxo de caixa descontado (FCD) resultou em um valor presente líquido (VPL) de R\$193,36 milhões, considerando uma taxa de crescimento da demanda diária de pico de $1 \%$ ao ano e um custo de capital de $12 \%$ a.a. O custo de capital adotado no estudo foi determinado com base na premissa de custo de capital adotada no Estudo de Viabilidade do BRT TransOeste feito pela Logit (2011). O valor do projeto estático correspondeu ao valor de mercado do projeto referido na Equação 1 como $V P L_{\text {estático. }}$ O Anexo 9.1 apresenta a estrutura sintética do fluxo de caixa do projeto estático no período referido.

\subsubsection{Análise neutra ao risco}

De acordo com Freitas \& Brandão (2009), os modelos de precificação de opções utilizados para se obter uma solução exigem que seja adotada uma medida neutra ao risco, que é feita por meio da dedução do prêmio de risco $(\zeta)$ da taxa de retorno do ativo e do desconto do fluxo de caixa do projeto pela taxa livre de risco. Dessa forma, o processo de difusão do ativo neutro ao risco pôde ser representado na forma $d P_{R}=(\mu-\zeta) P_{R} d t+\sigma P_{R} d z$.

Freitas \& Brandão (2009) afirmam que é possível obter o prêmio de risco observando-o diretamente no mercado ou determinando-o por meio da fórmula do CAPM, onde $\mu=r f+\beta\left(E\left[R_{m}\right]-r f\right)$ e o prêmio de risco é dado por $\zeta=$ $\beta\left(E\left[R_{m}\right]-r f\right)$. Deste modo, torna-se possível a adoção da medida neutra ao risco por meio da taxa $r f$, uma vez que $r f=\mu-\zeta$.

Contudo, os autores ressaltam que, para o caso de ativos cujo mercado é incompleto - como o da demanda de passageiros transportados - torna-se necessária a adoção de métodos indiretos para se determinar o prêmio de risco. 
Uma das formas utilizadas por Freitas \& Brandão (2009) para se determinar o prêmio de risco consiste no fato que o valor do projeto na avaliação neutra ao risco (sem a inclusão das eventuais opções existentes) deve ser idêntico ao valor do projeto estático, cujos fluxos seguem o processo de difusão verdadeiro e são descontados à taxa $\mu$. A Equação 30 representa a equiparação entre o valor projeto estático e o valor do projeto neutro ao risco:

$$
E\left[\sum_{i=1}^{t} \frac{f(P)}{(1+\mu)^{i}}\right]=E\left[\sum_{i=1}^{t} \frac{f\left(P_{R}\right)}{(1+\mu-\zeta)^{i}}\right]
$$

onde: $\quad d P=\mu P d t+\sigma P d z$

$$
d P_{R}=(\mu-\zeta) P_{R} d t+\sigma P_{R} d z
$$

$\zeta=$ prêmio de risco do projeto

$f(P)=$ fluxo de caixa do projeto estático

$f\left(P_{R}\right)=$ fluxo de caixa do projeto estático neutro ao risco

Considerando que todas as demais variáveis da Equação 30 são conhecidas e permanecem inalteradas, foi possível determinar o valor do prêmio de risco $\zeta$ da demanda de pico por equivalência através da ferramenta "Atingir meta" do Microsoft Excel, seguindo a mesma metodologia adotada pelos autores.

Com isso, foi possível obter o prêmio de risco $\zeta$ da taxa de crescimento da demanda de pico, que foi de $6,2642 \%$ a.a. A taxa de desconto livre de risco $r f$ adotada no modelo foi de $4,5 \%$ a.a, que corresponde à taxa básica de juros da economia brasileira vigente em dezembro de 2019 (SELIC). O Anexo I.B apresenta o fluxo de caixa do projeto avaliado pela abordagem neutra ao risco e os valores obtidos.

\subsection{Modelo de árvores de decisão binomial do BRT TransOeste}

Para a avaliação do projeto pelo método das Opções Reais, foi adotado o modelo binomial de precificação de opções de Cox, Ross e Rubinstein (1979). Segundo Freitas \& Brandão (2009), a precificação por Opções Reais tem como objetivo oferecer indicações a respeito da decisão ótima e da avaliação do valor ótimo de um projeto. Em comparação com o método tradicional do FCD, a teoria das Opções Reais possibilita incluir a modelagem de variáveis de incerteza do ambiente e dos elementos de flexibilidade gerencial decorrentes destas incertezas dentro do escopo de avaliação do projeto. As seções 5.6.1 e 5.6.2 descreveram 
os parâmetros de incerteza e flexibilidade do modelo binomial desenvolvido neste estudo.

\subsubsection{Parâmetros de incerteza do projeto}

A Tabela 14 resumiu os parâmetros assumidos para calcular a variável de incerteza do modelo binomial. Dentre os valores listados na tabela estão o parâmetro de volatilidade da demanda de pico $\sigma$, o valor inicial da variável de incerteza da demanda de pico $P_{0}$, a taxa livre de risco e o valor do projeto estático, já definidos no início deste capítulo. O período discreto de difusão da variável de incerteza $d t$ equivale a um ano. O tempo de duração do projeto avaliado neste estudo compreendeu a um período de treze anos, que equivale ao tempo de duração da concessão dos consórcios de ônibus do município do Rio de Janeiro a partir do ano de 2019.

Com os dados citados, foi possível estimar os parâmetros de subida e descida de difusão da variável de incerteza da árvore binomial $u$ e $d$, bem como a probabilidade de subida da variável de incerteza $p$. O valor do projeto-base, sobre o qual foi calculado o valor do projeto expandido e das opções, equivaleu ao VPL do fluxo de caixa estático do projeto, no valor de $\mathrm{R} \$ 193,36$ milhões.

\begin{tabular}{|c|c|}
\hline Descrição & Valor \\
\hline Projeto-base & $193,36 \mathrm{MM}$ \\
\hline$P_{0}$ & 18.807 \\
\hline$\sigma$ & $12 \%$ a.a \\
\hline$d t$ & 1 \\
\hline$r f$ & $4,5 \%$ a.a \\
\hline$u$ & 1,1275 \\
\hline$d$ & 0,8869 \\
\hline$p$ & 0,6571 \\
\hline
\end{tabular}

Tabela 16: Parâmetros do modelo binomial. Fonte: o Autor.

\subsubsection{Parâmetros estocásticos do modelo de Opções Reais}

Com a incorporação do processo de difusão estocástica no cálculo da demanda de pico do projeto original, houve a necessidade de se adaptarem alguns dos parâmetros utilizados para estimar as receitas e os custos do fluxo de caixa do projeto. Particularmente, três parâmetros estão diretamente vinculados à esta variável de incerteza: a demanda diária de passageiros transportados diariamente, a frota de veículos necessária para atender esta demanda em cada hora do dia, e o total acumulado de quilômetros rodados por esta frota em cada dia operacional. As seções 5.5.3.1 a 5.5.3.3 explicam as adaptações feitas nestas variáveis para 
que o fluxo de caixa do projeto expandido refletisse a inclusão do parâmetro de incerteza do modelo de Opções Reais.

\subsection{Estimativa da demanda total diária estocástica}

Para se estimar a receita tarifária do projeto, deve-se tomar como base de cálculo a demanda total de passageiros transportados ao longo do dia, conforme foi definido na seção 5.4.1.1.1. Dado que a variável de incerteza adotada no modelo representa somente a demanda de passageiros transportada no horário de pico, optou-se por estimar a volatilidade da demanda total diária de passageiros com base em duas variáveis: a volatilidade da demanda de pico (representada pela variação contínua da demanda de pico estocástica no ano $t$ sobre a demanda de pico do ano-base) e a correlação observada entre a série histórica da demanda de passageiros transportados no horário de pico e a demanda total de passageiros transportados ao longo do dia. Foram tomados como valores-base a média total de passageiros transportados no horário de pico em 2019 e a média diária de passageiros transportados no mesmo ano - 18.087 e 186.239 passageiros, respectivamente. A Figura 14 apresenta as séries históricas de passageiros transportados no corredor BRT TransOeste nos horários de pico e a demanda diária total de passageiros transportados no mesmo corredor nos dias úteis (segunda a sexta-feira, incluindo dias de feriado com demanda mais baixa) entre janeiro de 2016 e março de 2019. 
BRT TransOeste

Demanda de pico x Demanda diária (DU)

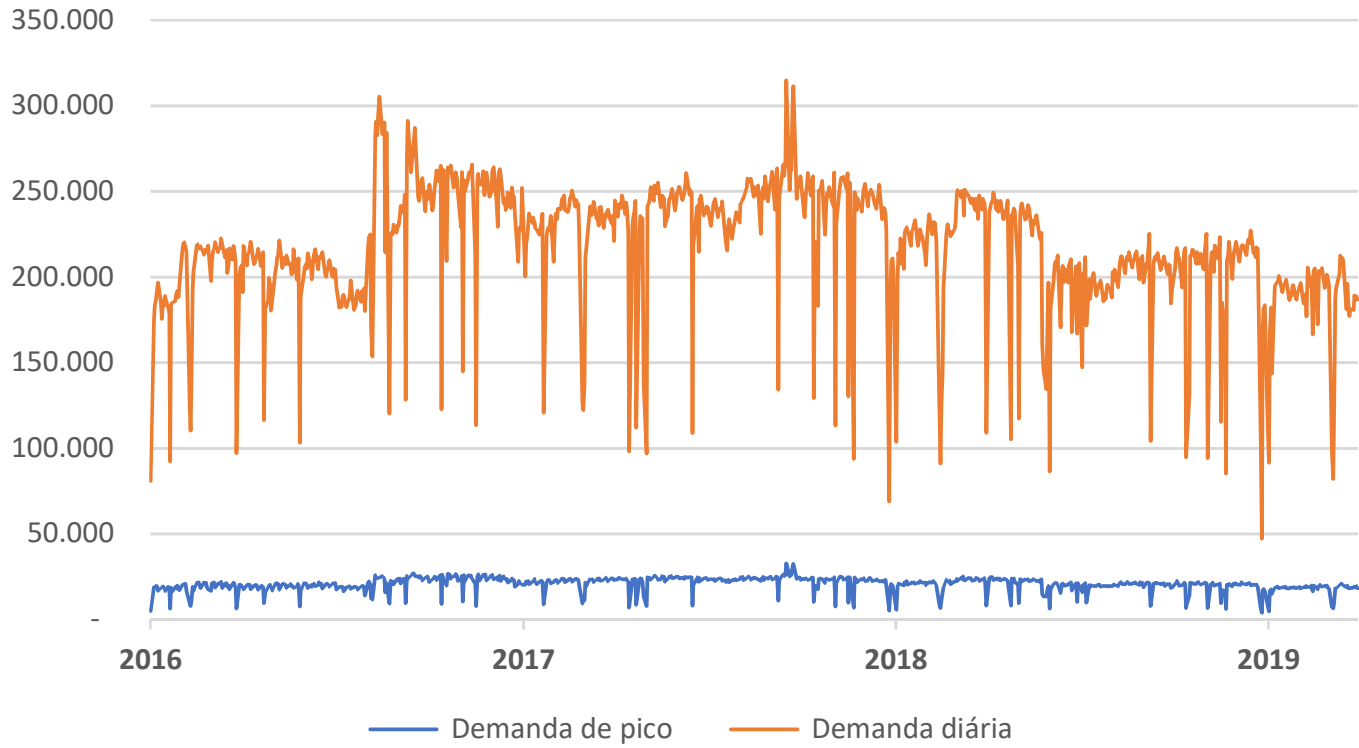

Figura 14: Demanda de pico $\times$ Demanda total diária por dia útil.

Base de dados disponibilizada pelo Consórcio Operacional BRT Rio.

A análise conjunta das duas séries históricas possibilitou estabelecer um coeficiente de correlação $\rho$ da variação ocorrida nelas. Dessa, foi possível estimar um coeficiente de $\rho$ de 0,946872476 , o que significa que existe um grau de correlação muito forte entre a variação ocorrida na demanda de passageiros transportados no horário de pico e a variação da demanda de passageiros transportados ao longo do dia. Com isto, foi possível determinar a fórmula utilizada para estimar a demanda total diária de passageiros estocástica utilizada no modelo de Opções Reais, representada pela Equação 31:

$$
\text { TOTPAX } X_{t}=\text { TOTPAX } X_{0} * e^{L N\left(\frac{P_{t}}{P_{0}}\right) \rho}
$$

onde TOTPAX $X_{t}$ é a demanda total diária calculada no ano $t, P_{t}$ é a demanda estocástica do horário de pico no ano $t$, e $\rho$ é o coeficiente de correlação entre a demanda diária e a demanda do horário de pico $(0,946872476)$. Os valores adotados para $P_{0}$ e TOTPAX $X_{0}$ foram 18.807 e 186.239, respectivamente.

\subsection{Redimensionamento das estações}

O cálculo do montante de investimentos necessários para redimensionar as estações após a inclusão da abordagem das Opções Reais assumiu como premissa a variação estocástica do fluxo máximo observado de passageiros de 
cada estação descrito na Tabela 14. A variação estocástica dos fluxos máximos de demanda em cada estação seguiu a mesma metodologia utilizada para estimar a demanda total diária de passageiros da seção 5.6.1.1.2. Assim, o cálculo do investimento para redimensionar o tamanho das estações ocorreu somente nos cenários em que o fluxo máximo de passageiros estocástico de uma determinada estação ultrapassou o limite de capacidade máxima estimado na mesma, conforme os limites estabelecidos na Tabela 15.

\subsection{Estimativa da frota diária estocástica}

Para estimar o tamanho da frota necessário para atender a demanda estocástica, foi utilizada a mesma fórmula utilizada para estimar a frota do projeto original, descrita na Equação 6. A única alteração ocorrida se deu por conta da incorporação do fator estocástico na variação da demanda de pico, sendo mantidos inalterados os demais parâmetros. O cálculo do tamanho da frota estocástica diária no horário de pico do modelo de Opções Reais pôde ser representado pela Equação 32:

$$
n B R T_{t}=\frac{P_{t}}{\gamma * c}
$$

onde $\gamma=0,8$ e $c=202$.

\subsection{Estimativa da quilometragem percorrida estocástica}

O redimensionamento de frota causado pela variação da demanda de passageiros estocástica acarretou também numa variação da quilometragem percorrida pela frota de veículos, que por sua vez acarretou a variação dos custos e despesas operacionais, das despesas de depreciação e necessidades de investimento decorrentes deste redimensionamento. Para estimar o total acumulado de quilômetros percorridos pela frota, foi utilizado um cálculo similar ao da seção 5.3.3.1. Multiplicando-se o valor da frota do ano-base no horário $i$ pela variação contínua da frota do ano $t$ no horário $i$ sobre a frota do ano-base no horário $i$, pôde-se chegar ao total acumulado de quilômetros percorridos pela frota de veículos ao longo do dia. A Equação 33 representou a estimativa deste parâmetro. 


$$
\operatorname{TotKm}_{t}=\sum_{i=1}^{24} K m H * F_{i 0} * e^{L N\left(\frac{n B R T_{t}}{n B R T_{0}}\right)}=T o t K m_{0} * e^{L N\left(\frac{n B R T_{t}}{n B R T_{0}}\right)}
$$

onde $n B R T_{t}$ é o tamanho a frota do horário de pico do ano $t$, e $F_{i 0}$ é a frota do ano-base no horário $i$. Os dados sobre a frota do ano-base estão na Tabela 6. O valor calculado de $\mathrm{TotKm}_{0}$ foi de $34.260 \mathrm{~km}$.

\subsubsection{Parâmetros de flexibilidade do projeto}

Após terem sido feitas as adaptações nos parâmetros para que refletissem as mudanças ocorridas no elemento de incerteza do projeto, o passo seguinte consistiu na modelagem dos parâmetros de flexibilidade da árvore de decisão do modelo binomial. No tocante aos parâmetros da flexibilidade, o modelo de expansão da capacidade de passageiros do corredor BRT TransOeste assumiu três premissas: (1) a opção de expandir a capacidade de passageiros pode ser exercida em qualquer período de decisão até o prazo de vencimento do projeto; (2) a opção de expandir a capacidade pode ser adiada em qualquer período de decisão ao longo do período até o vencimento; e (3) as opções de expansão e adiamento pode ser exercidas de forma consecutiva ou alternada em qualquer período de decisão.

Desta forma, o modelo do projeto do BRT TransOeste na abordagem de Opções Reais pode ser entendido como uma opção americana em tempo discreto, no qual a decisões de expansão ou adiamento da expansão da capacidade de passageiros transportados podem ser realizadas múltiplas vezes em cada ano de decisão até o vencimento. Nesses processos de múltiplas decisões, foram gerados caminhos de decisão distintos e, consequentemente, foram gerados fluxos de caixa interdependentes entre si. A Figura 15 ilustra o diagrama do modelo binomial de Opções Reais até o ano 05. 


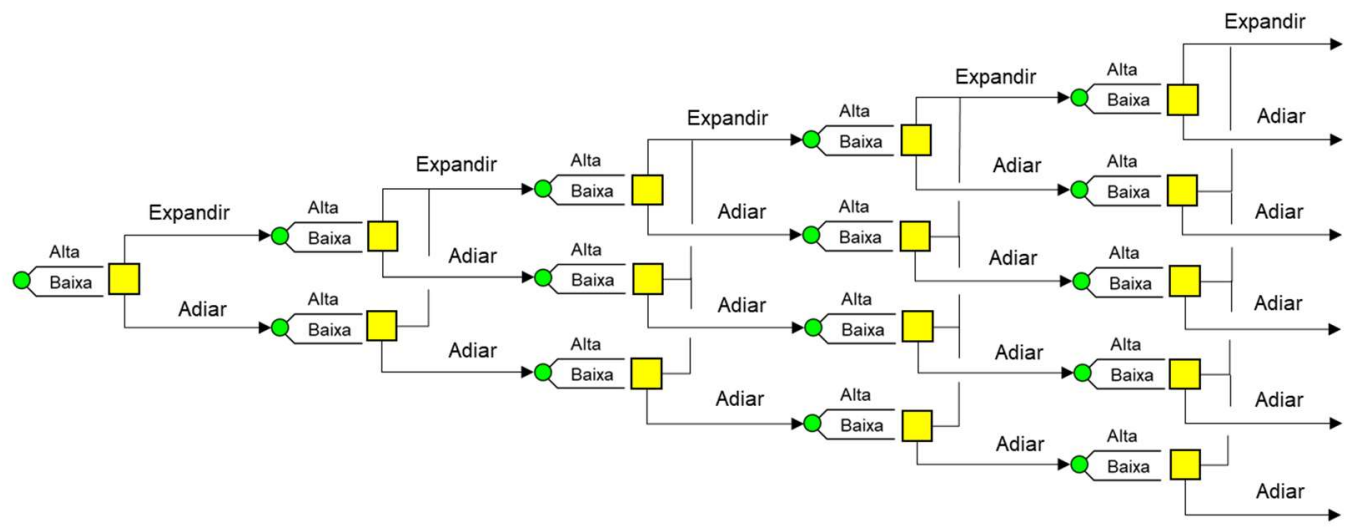

Figura 15: Diagrama do modelo binomial.

Fonte: o Autor

\subsubsection{Opção de expandir a capacidade de passageiros do horário de pico - expansões consecutivas}

Nos nós de decisão em que a opção de expandir a demanda de pico foi exercida e não houveram decisões de adiamento da expansão em anos anteriores e posteriores, o fluxo de caixa do projeto do ano $t$ refletiu exatamente a variação estocástica da demanda de pico $P$ entre os anos de decisão, com a consequente variação no volume de receitas e nos custos operacionais incorridos ao longo do projeto.

A decisão de redimensionar a frota de veículos do corredor levou em consideração o caminho estocástico percorrido pela variável de incerteza da demanda de pico até um determinado ano $t$. Nos cenários em que a demanda de pico do ano $t$ tenha sido superior à demanda de pico do ano $t-1$ e o tamanho da frota máxima do ano $t$ - que seria necessariamente a mesma do ano $t-1$ - não tenha sido suficiente para comportar uma demanda de pico superior à sua capacidade, houve a necessidade de se investir na aquisição de novos veículos para redimensionar o tamanho da frota no ano $t$ de modo que a mesma passasse a refletir a nova demanda expandida de passageiros no horário de pico do ano $t$. Por outro lado, nos cenários em que a demanda de pico $P$ do ano $t$ fosse inferior à do ano $t-1$ ou que o tamanho da frota de veículos de $t-1$ tenha sido superior ao necessário para comportar a demanda de pico estocástica $P$ do ano $t$, não foi aplicada a necessidade de redimensionamento do tamanho da frota $\left(\right.$ CAPEX Redim $\left._{t}\right)$. Essa regra também se aplicou aos casos de redimensionamento 
do tamanho das estações por meio da comparação entre o fluxo estocástico de passageiros por estação e seus respectivos limites de capacidade máxima.

Assim, a Equação 34 descreve as condições de aplicação do $C_{\text {CPEX }}$ Redim $_{t}$ nos nós de decisão onde foi exercida a opção de expansão da demanda de pico do corredor BRT TransOeste, considerando que não ocorreu o exercício de opções de adiamentos prévios ou posteriores:

$$
{\text { CAPEX } \text { Redim }_{t}}=\left\{\begin{array}{rr}
\frac{\left(P_{t}-P_{t-1}\right)}{\gamma * c} * V M_{-} B R T, & \text { se } n B R T_{t}>n B R T^{*} \\
0, & \text { se } n B R T_{t} \leq n B R T^{*}
\end{array}\right.
$$

\subsubsection{Opção de adiar a expansão da demanda de passageiros no horário de pico}

Necessariamente, o exercício da opção de adiamento da expansão da demanda de pico equivale ao exercício da opção de não-expansão da demanda de pico, que consiste em manter a capacidade máxima de passageiros transportados inalterada. Ou seja, nos períodos de decisão onde a opção de adiamento da expansão da demanda de pico foi exercida, foi incluída uma condição de trava nos cenários de subida de $P$, de modo que a demanda de pico do referido período não pôde ser superior à demanda de pico $P$ do ano imediatamente anterior. Nos casos em que houve não apenas uma, mas uma série de opções consecutivas de adiamento da expansão da demanda de pico, foi mantida a mesma condição de trava de subida do valor de $P$ ao longo de toda a série consecutiva de opções de adiamento, ou seja, a demanda de pico $P$ máxima obtida nos fluxos de caixa destas séries consecutivas de opções de adiamento foi o mesmo valor de $P$ obtido no período imediatamente anterior à primeira opção de adiamento exercida nesta série. Assim, a demanda de pico máxima das séries consecutivas de opções de adiamento da demanda de pico foi denominado $P_{t . l}$, onde $l$ corresponde ao ano de exercício da primeira opção de adiamento nesta série consecutiva de opções de adiamento, cujo valor máximo obtido equivale ao valor de $P$ obtido no período $l-1$. Nos cenários em que o valor estocástico de $P$ foi inferior a $P_{t . l}$, a condição da trava de subida $P_{t . l}$ não se aplicou, de modo que a demanda de pico $P_{t . l}$ foi exatamente igual à demanda de pico estocástica $P$. A Equação 35 exemplificou a condição dos fluxos de caixa $f(P)$ das séries consecutivas de adiamento da expansão da demanda de pico: 


$$
f(P)= \begin{cases}f\left(P_{t . l}\right), & \text { se } P>P_{t . l} \\ f(P), & \text { se } P \leq P_{t . l}\end{cases}
$$

Onde $l$ equivale ao ano de exercício da primeira opção de adiamento da série consecutiva de adiamentos, e $l<t$. Vale salientar que a demanda de pico $P_{t . l}$ segue exatamente o mesmo processo de difusão de $P$; a diferença ocorrida entre as demandas de pico $P_{t . l}$ e $P$ se deu por conta da trava de subida que foi incluída no caso da opção de adiamento no período $l$, ou seja, nos casos em que $P_{t . l}$ foi superior à $P$, o valor máximo obtido foi $P_{t . l}$; na situação contrária, $P_{t . l}$ equivaleu ao valor estocástico de $P$.

A inclusão travas de subida das opções de adiamento da expansão da demanda de pico implicou em uma situação na qual foi gerada uma sucessão de caminhos paralelos e distintos em função dos diferentes períodos $l$ nos quais a opção de expansão foi passível de ser exercida. Por exemplo: em um cenário hipotético onde a demanda de pico estocástica $P$ tenha crescido consecutivamente ao longo dos anos $t-2$ e $t$, foram exercidas as opções de expandir a demanda de pico no ano $t$-2 e de adiar a expansão da demanda de pico no ano $t-1$. Neste cenário de decisões, a demanda de pico da opção exercida em $t$-2 foi exatamente igual à demanda de pico estocástica deste respectivo período; no entanto, o fato de a opção de adiamento ter sido exercida no ano $t-1$ fez com que a demanda de pico da opção de adiamento do ano $t-1$ não pudesse ser superior à demanda de pico estocástica do ano $t-2$. Em um segundo cenário hipotético distinto do primeiro cenário citado, foram exercidas as opções de adiamento da expansão tanto no ano $t-2$ como no ano $t-1$. A diferença entre decisões tomadas nos dois cenários ao longo do mesmo período de tempo resultou em um cenário de geração de caminhos paralelos distintos um do outro, de modo que a demanda de pico máxima deste segundo cenário seria a mesma entre os anos $t$-2 e $t$-1. A Figura 16 ilustra os caminhos percorridos em função de cada decisão tomada nos períodos em questão. 


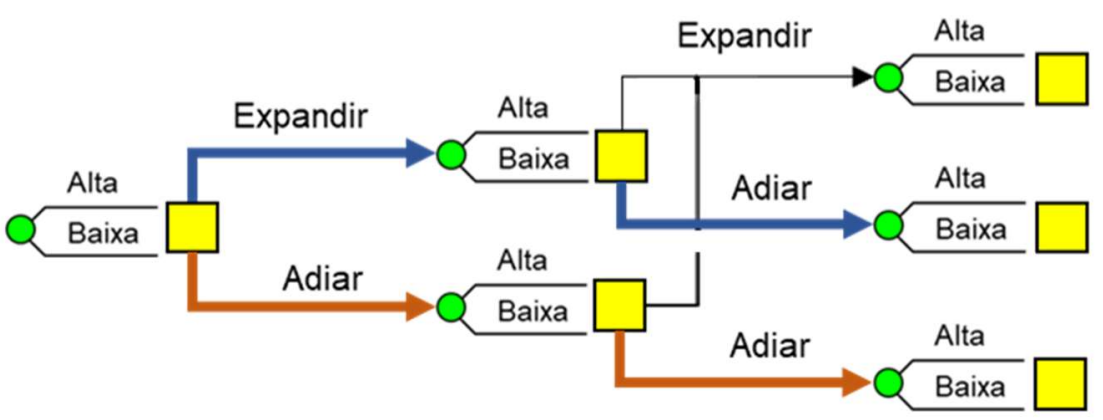

Figura 16: Opção de adiar a expansão em dois períodos.

Fonte: o Autor

O trajeto do segundo cenário (em laranja escuro) explica o caso das séries de opções de adiamento consecutivas, de modo que a demanda de pico máxima dos fluxos de caixa $f\left(P_{t . l}\right)$ deste cenário permaneceu inalterada. Neste cenário, o período $l$ de trava da subida da demanda de pico corresponde ao ano $t-2$. No primeiro cenário (em azul escuro), por conta do exercício da opção de adiamento da expansão realizado no ano $t-1$, o fluxo de caixa $f\left(P_{t . l}\right)$ do referido período foi calculado em função da demanda de pico com trava de subida, dado que a demanda de pico do ano $t-1$ não pode ser superior à demanda de pico do ano $t-2$. Analisando conjuntamente os dois cenários, é possível observar que os ambos possuem períodos de trava de demanda $l$ distintos, dado que nos dois casos as opções de adiamento não-consecutivas ocorreram em períodos distintos (em $t$-2 e $t$-1). Assim, é possível representar os fluxos de caixa dos dois cenários como $f\left(P_{t . t-2}\right)$ e $f\left(P_{t . t-1}\right)$, respectivamente. Vale ressaltar ainda que, em cada um dos caminhos de decisão gerados no modelo, independentemente das decisões realizadas em períodos anteriores ou posteriores, foi aplicada a mesma taxa de desconto $\mu$ nos fluxos de caixa paralelos contidos no mesmo período de decisão. Em outras palavras: no exemplo ilustrado na Figura 16, foi aplicada a mesma taxa de desconto $\mu$ para $f\left(P_{t . t-2}\right)$ e $f\left(P_{t . t-1}\right)$.

Tendo em vista a condição de inclusão da trava de subida da demanda de pico decorrente do exercício da opção de adiamento, nos fluxos de caixa $f\left(P_{t . l}\right)$ deste cenário não foi previsto o investimento para o redimensionamento da frota

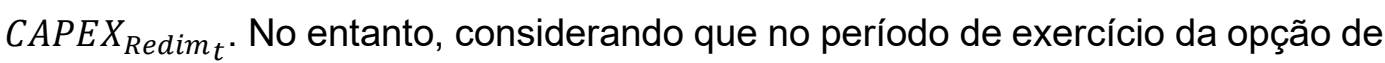
adiamento foi mantido o mesmo tamanho de frota do período anterior, foi adicionado ao fluxo de caixa $f\left(P_{t . l}\right)$ desta opção uma condição de conversão da frota de veículos excedente de períodos anteriores em receitas de revenda no período de exercício destas opções de adiamento. 
Assim, a Equação 36 representou a receita obtida pela revenda da frota de veículos excedente decorrente do exercício da opção de adiamento da expansão da demanda de pico (denominada $R n B R T_{t, l}$ ). Para o cálculo do valor residual de revenda, são levados em consideração o valor de revenda, o valor de mercado de cada veículo e as deduções das alíquotas de impostos e tributos aplicáveis sobre estas receitas.

$$
R n B R T_{t, l}=\left\{\begin{aligned}
0,05 * V M B R T *\left(\frac{P-P_{t . l}}{\gamma * c}\right) * 0,54615, & \text { se } P>P_{t . l} \\
0, & \text { se } P \leq P_{t . l}
\end{aligned}\right.
$$

\subsubsection{Opção de expandir a capacidade de passageiros do horário de pico - após a opção de adiamento}

No modelo de Opções Reais proposto neste estudo, a opção de expandir a capacidade da demanda de pico, com a condição de ter sido exercida a opção de adiamento no período imediatamente anterior, foi similar ao caso da opção de expandir a capacidade descrita na seção 5.6.1, porém, com uma característica particular. Dado que o exercício da opção de adiamento implicou no surgimento de uma variedade de caminhos paralelos em função dos limites de trava de subida de demanda ocorridos nos períodos $l$, foi gerada também uma condição adicional na qual os montantes de investimentos necessários para redimensionar o tamanho de frota de veículos desses diferentes estados de demanda com travas de subida $P_{t . l}$ para o estado de demanda sem trava de subida (ou seja, a própria demanda estocástica $P$ ) foram igualmente diferentes. Assim, o cálculo do valor do CAPEX $_{\text {Redim }_{t}}$ necessário para expandir o tamanho de frota das múltiplas demandas com trava de subida $P_{t . l}$ para o tamanho de frota expandido da demanda estocástica $P$ equivaleu quantidade de veículos necessária para comportar a diferença excedente de passageiros entre as múltiplas demandas de pico com trava de subida $P_{t . l}$ e a demanda de pico expandida $P$. Vale notar que a análise destas mudanças ocorridas entre os múltiplos cenários de demandas de pico com trava de subida $P_{t . l}$ e a demanda de pico expandida $P$ considerou as mudanças ocorridas dentro de um mesmo período de tempo $t$. O tamanho da frota de veículos dos múltiplos fluxos de caixa com trava de subida $f\left(P_{t . l}\right)$ foi denominado $n B R T_{t, l}$. A Equação 37 representou o valor de $C_{\text {aPEX }}$ Redim $_{t}$ necessário para redimensionar o tamanho de frota desses $P_{t . l}$ para comportar a nova demanda de pico expandida $P_{t}$. 


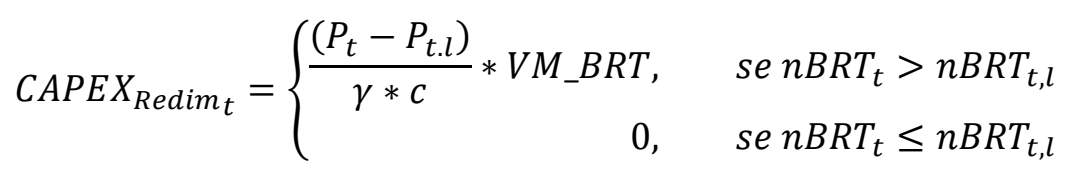

A Figura 17 exemplifica novamente os cenários descritos na Figura 16, porém com a diferença da adição do período $t+1$.

$\mathrm{t}-2$

$\mathrm{t}-1$

t

$t+1$

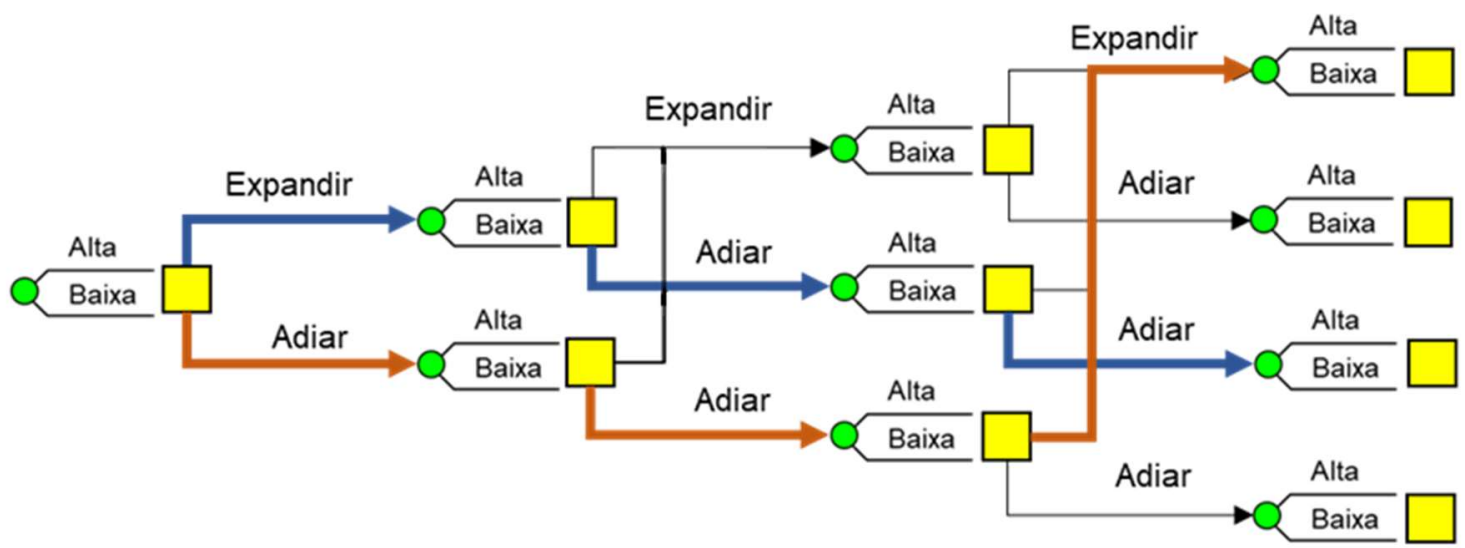

Figura 17: Opção de expandir, após opção de adiamento. Fonte: $O$ autor.

No cenário descrito na Figura 17, a variável estocástica da demanda de pico $P$ seguiu um caminho de crescimento ao longo de três períodos consecutivos. No caminho percorrido no cenário 2 , que se caracterizou pelo exercício de duas opções de adiamento consecutivas em $t$-2 e em $t-1$, foi exercida a opção de expansão da demanda de pico no ano $t$, de modo que a nova demanda de pico do cenário 2 passou a ser a demanda de pico da variável estocástica $P$, ou seja, $P_{t, t-2}$ passou a ser $P$. Assim, no cenário 2, o fluxo de caixa no ano $t$ passou a estar em função de $P$, se tornando $f(P)$. Por outro lado, no cenário 1 ocorreu a situação inversa; houve uma opção de expansão em $t$-2 seguida de duas opções de adiamento consecutivas em $t-1$ e $t$, de modo que no período $t$ foi mantida a trava de subida da demanda de pico realizado no período $t-1$, que corresponde ao período $l$ desse caminho. Logo, o fluxo de caixa da Decisão 1 no período $t$ permaneceu em função de $P_{t, t-1}$, ou $f\left(P_{t, t-1}\right)$. No caso de a opção exercida no cenário 1 no ano $t$ ter sido a de expandir a demanda de pico para $P$, assim como na Decisão 2, ambas passariam a estar em função de $P$, seguindo o processo de fluxo de caixa padrão $f(P)$. No entanto, devido às diferenças de trava de subida de demanda dos dois cenários, o valor de CAPEX $X_{\text {Redim }_{t}}$ calculado para cada um seria distinto, visto que a variação entre a demanda de pico com trava de subida 
$P_{t . t-1}$ e $P$, correspondente ao cenário 2 , foi maior que a variação ocorrida entre a demanda de pico com trava de subida $P_{t . t-2}$ e $P$ do cenário 1.

Por meio da análise das diferenças entre as valores distintos de $P_{t . l}$ de cada caminho em relação à demanda estocástica $P$, foi possível estimar um valor de CAPEX Redim $_{t}$ que correspondesse às mudanças de estado entre as opções de adiamento e a opção de expansão da demanda de pico. 


\section{Análise dos resultados do método de Opções Reais}

\subsection{Valor do projeto expandido e da opção}

A análise dos resultados do modelo sugeriu que o valor esperado do projeto do corredor BRT TransOeste avaliado pelo método das Opções Reais, com a incorporação das estratégias interativas de flexibilidade gerencial relativas às opções de expandir e/ou adiar a expansão da demanda de pico do corredor foi superior ao valor esperado do projeto estático, ou seja, sem o exercício destas opções. Com isso, o exercício da opção de ampliar a capacidade operacional do corredor BRT TransOeste, por meio da realização de investimentos na aquisição de veículos para redimensionar a frota operante e/ou a ampliação da capacidade das estações do corredor para que ele comporte um fluxo maior de passageiros, trouxe um incremento de $30,63 \%$ no valor esperado do projeto original, tendo ele passando de $\mathrm{R} \$ 193,36$ milhões para $\mathrm{R} \$ 252,59$ milhões. Após se subtrair o valor esperado do projeto estático do valor esperado do projeto expandido (ou seja, com a opção de expansão), foi possível obter, por fim, o valor da opção de expansão da capacidade do corredor BRT TransOeste, que totalizou R $\$ 59,23$ milhões. A Figura 18 mostra o valor esperado do projeto expandido calculado pelo modelo binomial desenvolvido neste estudo. 


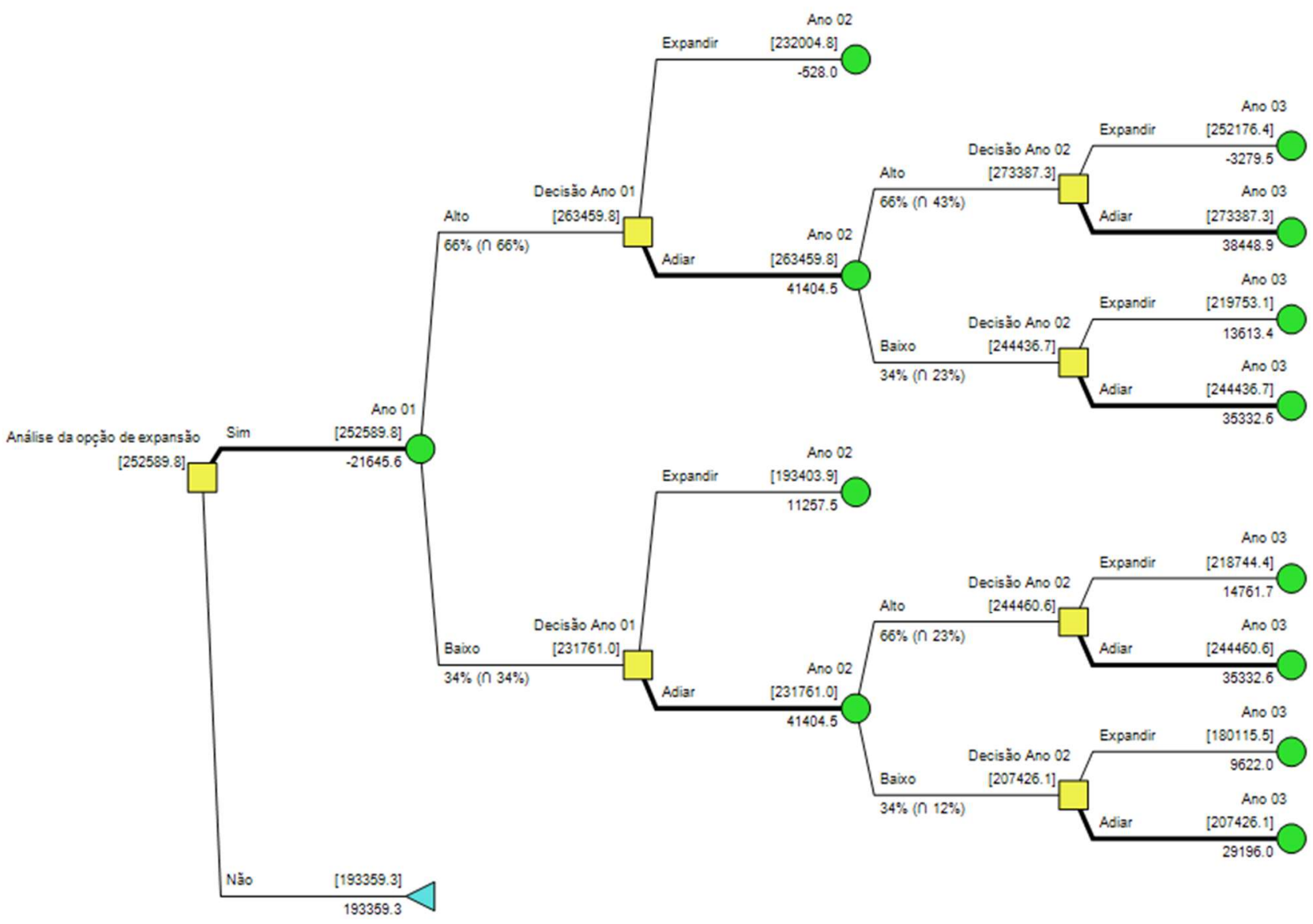

Figura 18: Valor esperado do projeto expandido pelo método das Opções Reais.

\subsection{Probabilidades da árvore de decisão por ano}

A análise do sumário de flexibilidade gerencial, onde são mostradas as probabilidades de exercício das opções de expansão da demanda de pico do corredor BRT TransOeste e/ou de adiamento da expansão ano a ano, mostrou que a opção de adiar, ou seja, de manter o mesmo nível de pico de demanda de anos anteriores, teve uma contribuição maior no aumento do valor do projeto em comparação com a opção de expandir a capacidade operacional do corredor. Os dados apresentados na Figura 20 mostram que a probabilidade de se exercer a opção de expansão da demanda de pico máxima do sistema ocorreu em maior grau de probabilidade apenas nos anos 6,7 e 13, sendo o ano 7 o ano em que a probabilidade de exercer a opção expandir o pico de demanda foi maior, com um total de $15 \%$ das vezes. Ainda assim, a probabilidade de exercício da opção de adiar foi a mais frequente em todos os períodos de decisão. 

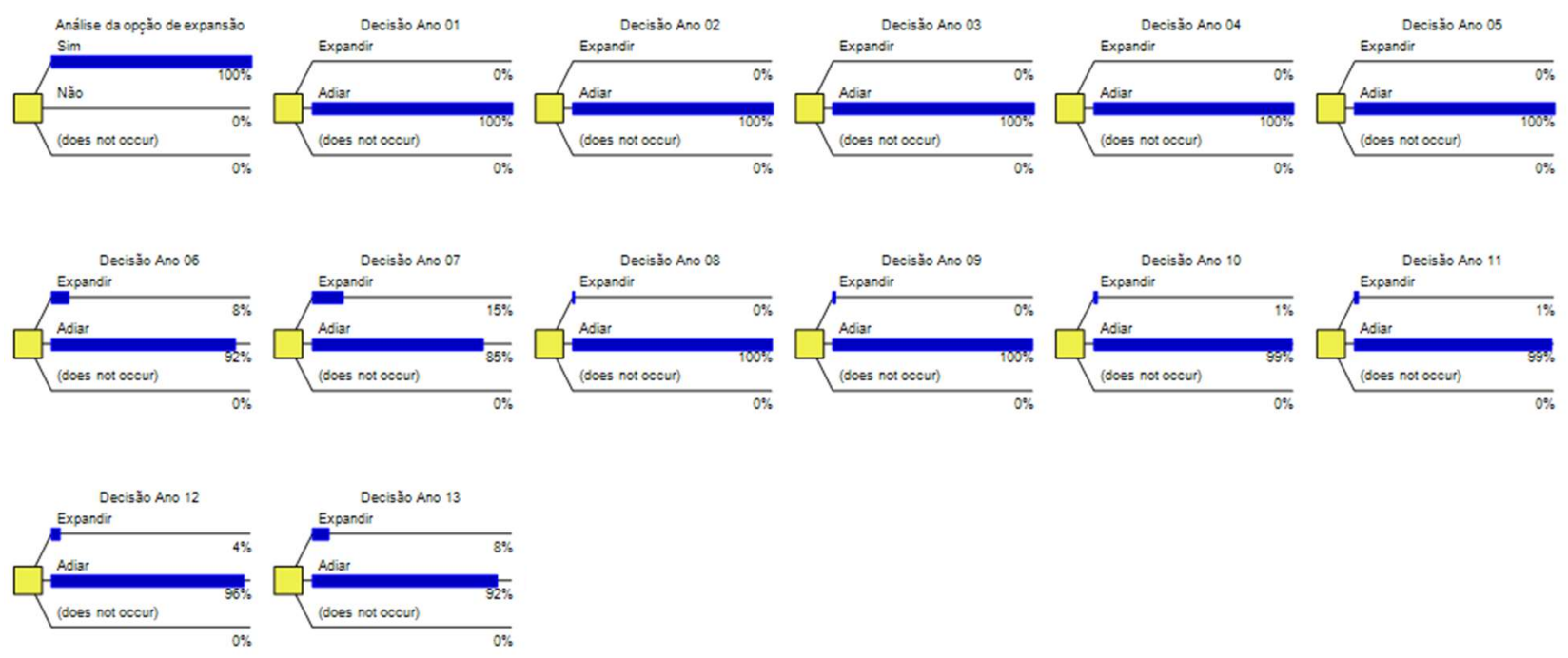

Figura 19: Sumário de decisões de expansão e adiamento pela abordagem neutra ao risco.

Estes resultados ocorreram principalmente em virtude da multiplicidade de cenários de opções de adiamento e expansão que foram gerados pelas condições de trava de subida da demanda de pico ocorridas nos períodos de decisão $l$. Como já foi citado anteriormente, as grandes diferenças de tamanho entre as demanda de pico com trava de subida $P_{t, l}$ e a demanda de pico expandida $P$ nos períodos de decisão $l$ causaram também uma variação proporcional no valor dos montantes de investimentos necessários para expandir as diferentes demandas de pico $P_{t, l}$ para a demanda de pico expandida $P$, o que por sua vez impactou consideravelmente os fluxos de caixa das opções de expansão.

Além disso, o aumento do tamanho da frota operante acarretou também o aumento do nível de investimentos necessários para renovar a frota de veículos que chegaram ao final da sua vida útil - que no modelo proposto neste estudo é de sete anos. Esta situação mostra que, para evitar o aumento dos níveis de investimento para renovação da frota de veículos, é mais viável do ponto de vista econômico manter o nível de operações constante.

A análise do sumário de probabilidades evidencia esta questão com clareza: a maior parte das opções de expansão da capacidade ocorreu nos períodos de decisão que correspondem ao período de renovação da frota de veículos do início do projeto. Nestes períodos, ocorreram cenários em que a opção de expandir o tamanho da frota de veículos contribuiu mais para aumentar do valor do projeto que a opção de adiar a expansão para o período seguinte.

A partir dos resultados descritos na árvore de decisão, pode se concluir que o ganho de valor gerado no projeto expandido é explicado pela combinação 
alternada das opções de expansão e adiamento ao longo da vida útil do projeto, considerando também que a opção por manter o mesmo nível de demanda de pico durante períodos consecutivos incorre em uma menor necessidade de investimento em ativos do projeto, tanto para o redimensionamento como para a renovação da frota.

\subsection{Análise de sensibilidade}

Após a análise do valor esperado do projeto expandido e do sumário de probabilidades de exercício das opções, foi realizado um estudo para avaliar a sensibilidade do valor esperado do projeto a uma mudança no valor do parâmetro de incerteza. Nesta análise, foram assumidos diferentes valores para a taxa de volatilidade da demanda de pico e o impacto desta variação no valor esperado do projeto expandido. $\mathrm{Na}$ análise, a taxa de volatilidade variou entre 8 e $16 \%$, para cima e para baixo. A Figura 20 mostra a variação do valor esperado do projeto expandido em função da variação da taxa de volatilidade.

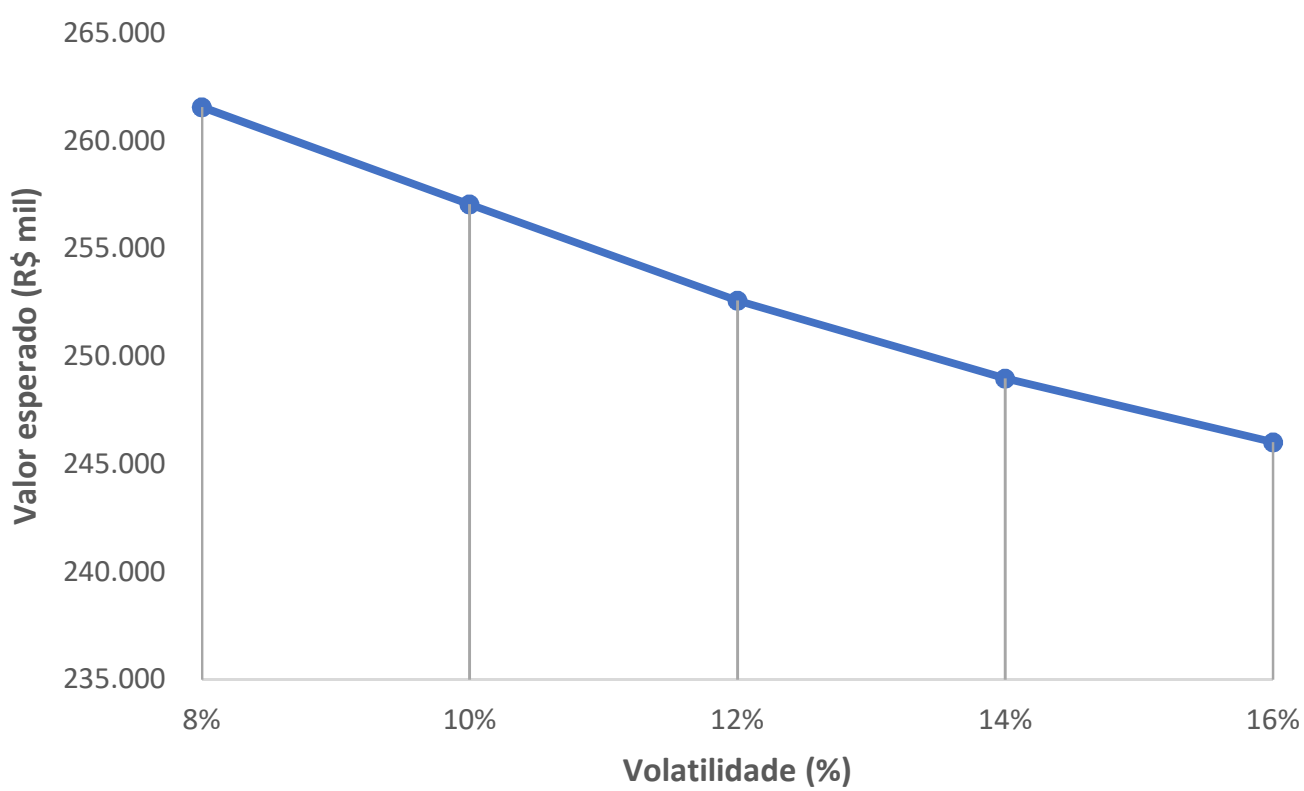

Figura 20: Análise de sensibilidade do valor esperado do projeto à taxa de volatilidade.

A análise de sensibilidade mostrou que o valor do projeto de expansão da capacidade do corredor BRT TransOeste variou de forma inversamente proporcional à variação da taxa de volatilidade, ou seja, conforme a taxa de volatilidade aumentou, o valor esperado do projeto expandido diminuiu. Esta 
variação é explicada de fato que, conforme aumenta a volatilidade da incerteza da demanda de pico, aumenta também a necessidade de gastos de capital para redimensionar o tamanho da frota de veículos, de modo que seja possível atender a um nível de demanda maior. Consequentemente, o aumento do tamanho da frota incorre necessariamente no aumento dos gastos de capital para renovar essa frota expandida. Esta situação faz com que o resultado dos fluxos de caixa nos cenários de maior volatilidade - especialmente nos cenários de subida da demanda de pico - apresentem resultados financeiros menores. Ao passo em que os gastos de capital de redimensionamento da frota influenciam mais fortemente os resultados financeiros dos fluxos de caixa nos nós de decisão onde a opção de expansão é exercida, os gastos de capital referentes à renovação da frota influenciam mais os resultados financeiros das opções de adiamento, fazendo com que sejam menores com o passar do tempo. Por outro lado, uma taxa de volatilidade menor implica em uma menor necessidade de gastos de capital, tanto para redimensionar como para renovar a frota de veículos, nos cenários de expansão e adiamento da demanda de pico.

No entanto, a mudança incremental gerada pela variação da taxa de volatilidade não representou uma variação considerável no valor esperado do projeto, visto que um incremento de $2 \%$ da taxa de volatilidade gerou uma variação de aproximadamente $\mathrm{R} \$ 4$ milhões do valor esperado do projeto expandido, o que representa um incremento ínfimo sobre valor do projeto (aproximadamente 1,8\%).

\subsection{Análise do projeto com a inclusão de incentivos governamentais}

Nesta seção, foi feita uma nova avaliação do projeto do corredor BRT TransOeste, considerando a inclusão de aportes de incentivos governamentais, com a finalidade de viabilizar a opção de expansão da capacidade do corredor.

\subsubsection{Despesas de capital para aquisição de ativos}

Um dos principais motivos que dificultam a viabilidade da expansão da capacidade do corredor BRT TransOeste diz respeito ao alto nível de gastos de capital necessários para ampliar a configuração atual do corredor, de modo que ele comporte um fluxo de passageiros maior, sem que isso resulte em um processo de saturação das operações. Assim, foi feita uma análise da variação ocorrida no valor esperado do projeto expandido quando considerada a hipótese de o poder concedente contribuir proporcionalmente no montante de gastos de capital para adquirir os ativos necessários para ampliar a capacidade operacional 
do corredor. Foi analisada a mudança ocorrida no valor esperado do projeto em função do aumento da proporção de participação do poder concedente nos investimentos necessários para expandir a capacidade do corredor BRT TransOeste.

Além de verificar se a participação do governo na aquisição dos ativos necessários para expandir a capacidade do corredor altera significativamente o valor esperado do projeto, esta análise foi realizada com o intuito de verificar se a diminuição do nível de gastos de capital do concessionário gerado pelo aumento da contribuição do poder concedente altera também as probabilidades da flexibilidade gerencial do projeto. A Figura 21 mostra a variação do valor esperado do projeto expandido em função do aumento da proporção de investimentos do poder concedente. Foram consideradas quatro proporções de investimento: (1) $25 \%$ do poder concedente e $75 \%$ da concessionária, (2) $50 \%$ para cada parte, (3) $75 \%$ do poder concedente e $25 \%$ da concessionária e (4) $100 \%$ integralmente investidos pelo poder concedente. Vale ressaltar que essa proporção não se aplica aos gastos de capital para renovação da frota de veículos, somente aos investimentos para redimensionamento da frota.

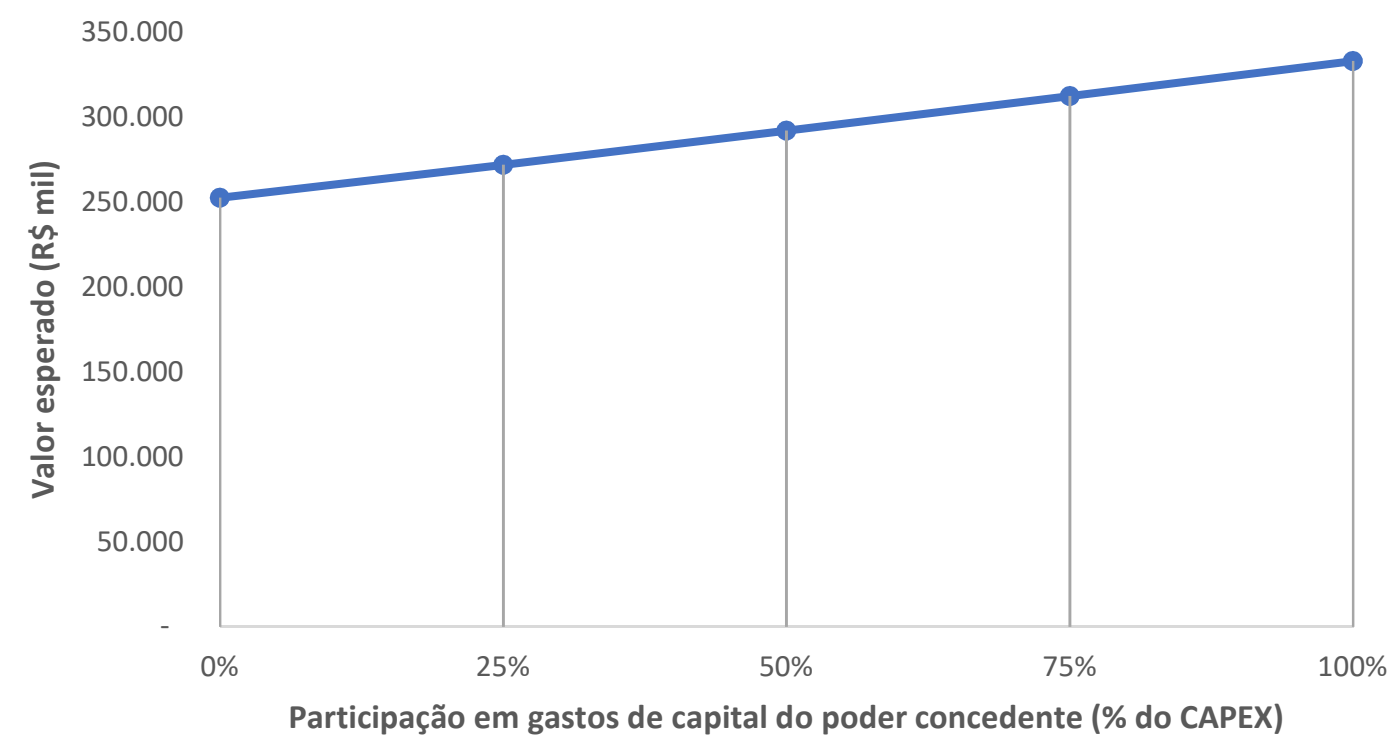

Figura 21: Valor esperado do projeto x participação \% em gastos de capital para a expansão do sistema.

Os resultados da análise mostraram que, à medida em que aumenta a proporção do poder concedente no aporte de recursos para a aquisição dos ativos necessários para expandir a capacidade do corredor, o valor esperado do projeto também aumenta. A Figura 21 mostrou que um aumento de $25 \%$ na proporção de gastos de capital cobertos pelo poder concedente gera um incremento de cerca 
de $\mathrm{R} \$ 20$ milhões ao valor esperado do projeto expandido, o que representa um aumento de cerca de $8 \%$ desse valor. Com isso, o valor da opção de expansão aumentou em aproximadamente $34 \%$ de $R \$ 59,23$ milhões para 79,23 milhões.

No entanto, os resultados dos sumários de probabilidades mostraram que o aumento da participação do poder concedente não resultou em uma alteração significativa dos resultados das decisões de flexibilidade, uma vez que a opção de adiar a expansão da capacidade se manteve como a opção que mais contribuiu no aumento do valor do projeto, em comparação com a opção de expandir a capacidade máxima do corredor. Apesar de as probabilidades de expansão terem aumentado sensivelmente, a opção por manter o nível de capacidade constante prevaleceu em todos os períodos. As Figuras 22 e 23 mostram que as probabilidades permaneceram quase inalteradas, com a exceção das decisões nos anos 4 e 7 , aonde foram observados o aumento das probabilidades de exercício da opção de expansão da demanda de pico. O aumento da probabilidade de exercício da opção de expansão desses períodos ocorreu nos cenários em que o poder concedente contribuiu proporcionalmente com $50 \%$ do montante de gastos de capital ou mais.
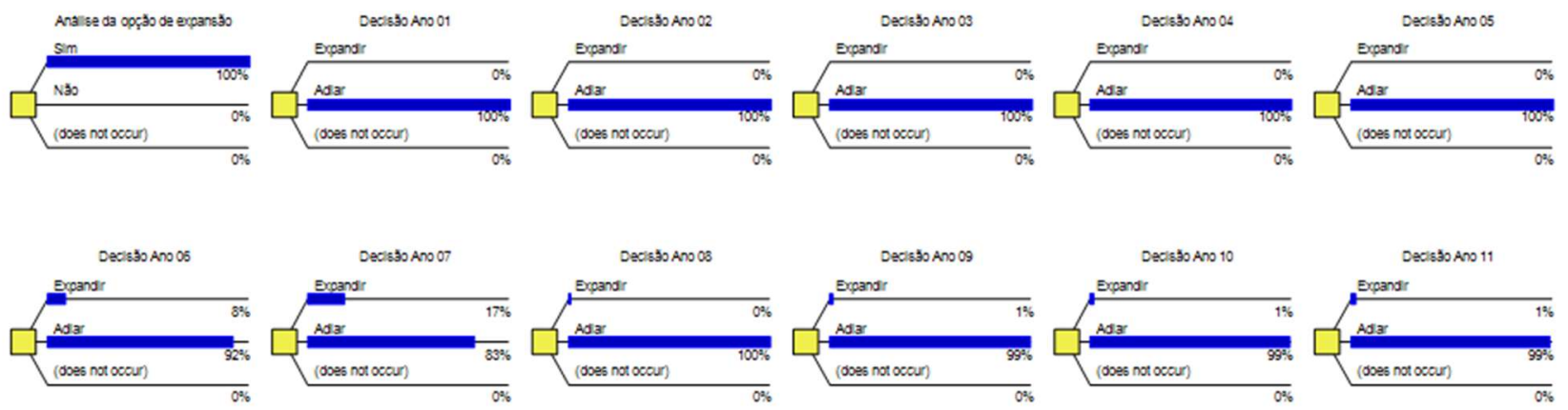

Decisbo Ano 11
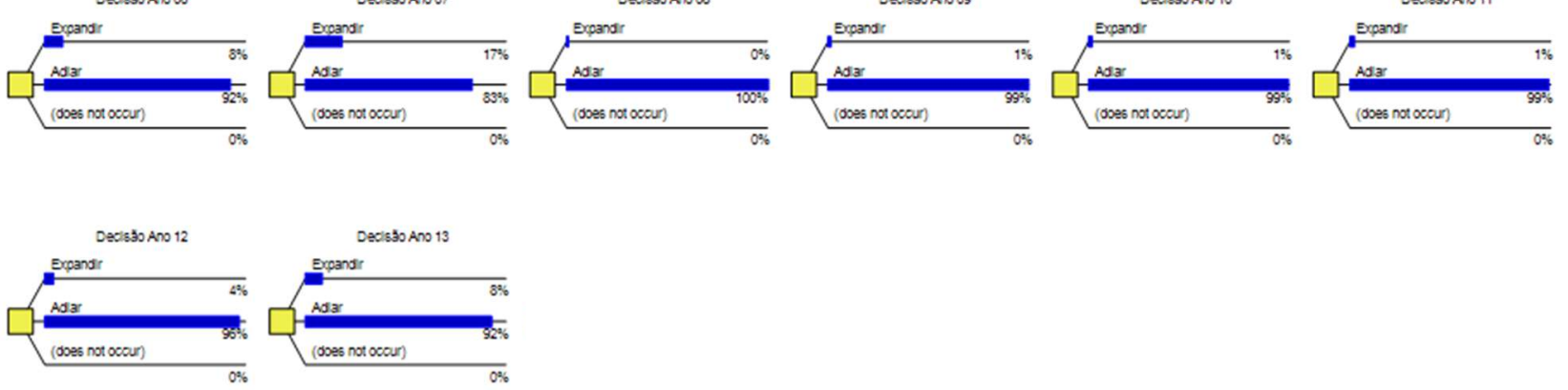

Figura 22: Sumário de probabilidades da participação do poder concedente (25\%). 

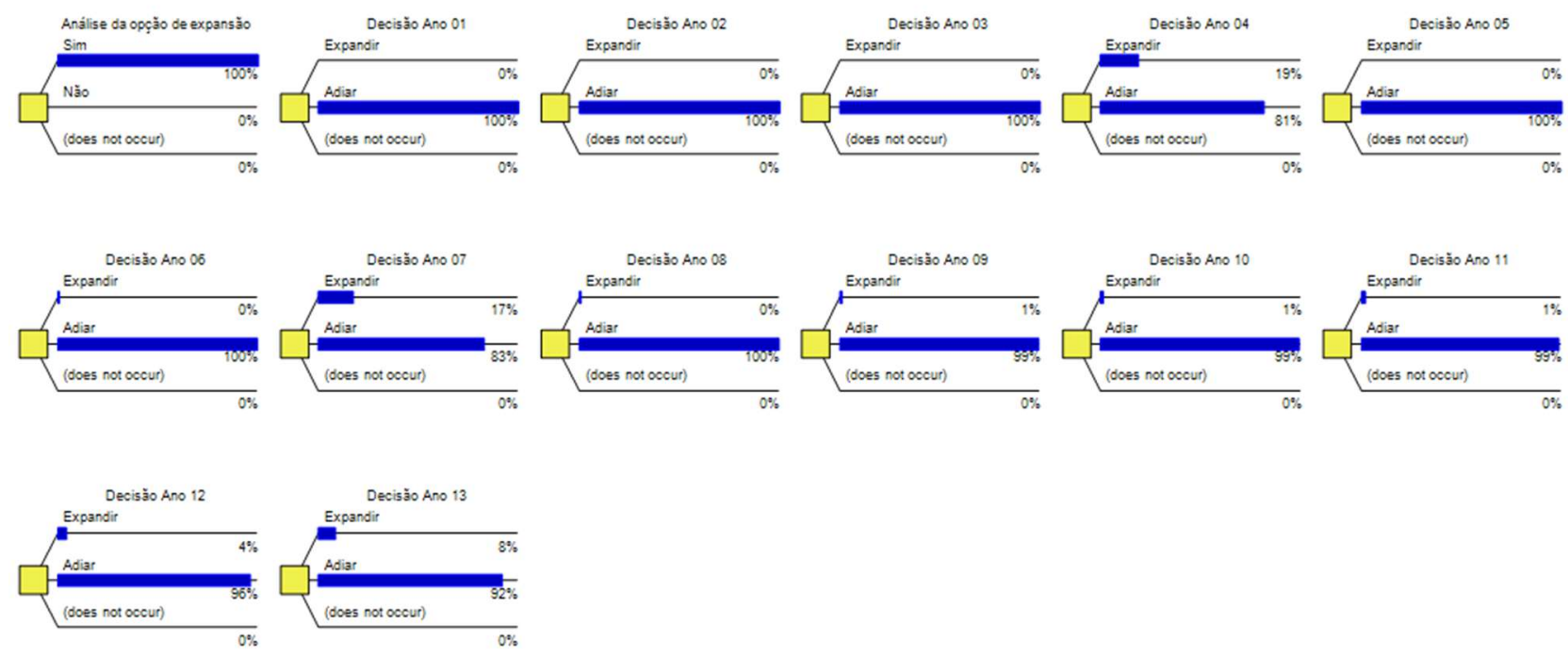

Figura 23: Sumário de probabilidades da participação do poder concedente $(50 \%)$.

\subsubsection{Mitigação de risco de evasão de passageiros}

Um dos pontos críticos relatados no Relatório de Intervenção do BRT do Rio diz respeito à receita tarifária perdida por conta do elevado índice de evasão de passageiros que usam o sistema sem pagar. Levando em conta esta questão, bem como a possibilidade de o poder concedente propor medidas para mitigar esse risco de demanda, foi feita uma análise da mudança ocorrida no valor esperado do projeto em função da cobertura de uma parte deste índice de evasão de passageiros, que corresponde a aproximadamente $9,5 \%$ da demanda diária em dias úteis. Neste cenário, o poder concedente se comprometeria com uma fração da receita perdida por evasão em benefício da concessionária. 


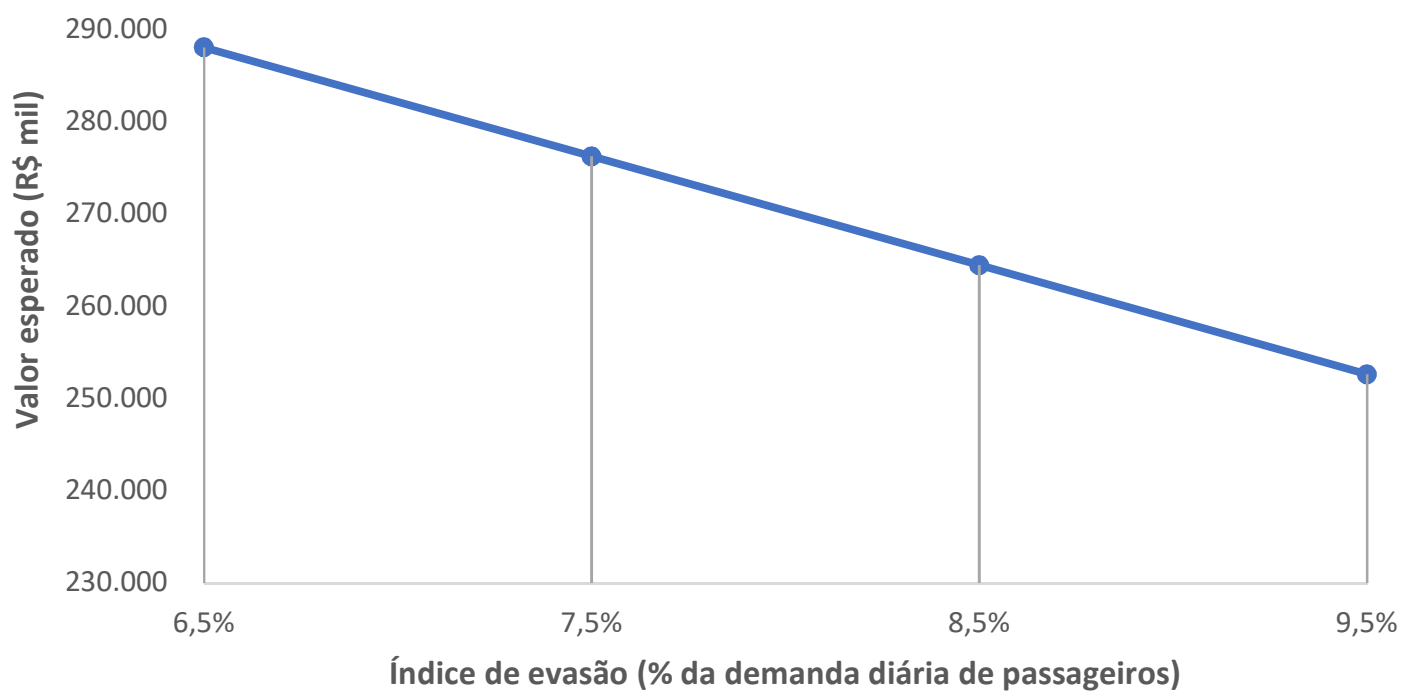

Figura 24: Valor esperado do projeto $x$ índice de evasão de passageiros.

A análise mostrou que a diminuição do risco causado pelo elevado índice de evasão de passageiros gerou um aumento considerável no valor esperado do projeto expandido, dado que a diminuição de $1 \%$ do índice de evasão de receita tarifária gerou um incremento de aproximadamente $\mathrm{R} \$ 12$ milhões no valor esperado do projeto expandido, o que representa proporcionalmente um incremento de $10 \%$. Com isto, o valor da opção de expansão do corredor BRT TransOeste aumenta em aproximadamente 20\% (R\$ 12 milhões sobre $R \$ 59,23$ milhões). 


\section{Conclusões}

Neste estudo foi desenvolvido um modelo para analisar o valor da opção de expansão da capacidade máxima de passageiros transportados no corredor BRT TransOeste pelo prisma da teoria das Opções Reais. O modelo foi desenvolvido a partir da combinação de uma metodologia de FCD desenvolvida para avaliar projetos de serviço de transporte público operado por ônibus e BRT e do modelo binomial de precificação de opções de Cox , Ross e Rubinstein (1979). Para a elaboração do modelo aplicado ao corredor BRT TransOeste, foram utilizados dados operacionais reais do sistema BRT do Rio de Janeiro fornecidos pelo Consórcio Operacional BRT para a realização deste estudo.

Dada à escassez de dados financeiros relativos ao sistema BRT Rio, pelo fato de tais informações não estarem devidamente discriminadas nos relatórios financeiros e balanços das operadoras consorciadas que operam o BRT e pelo fato de parte relevantes destes dados não estarem disponíveis para consulta, optou-se por mensurar o valor do projeto através da definição de parâmetros baseados em dados reais disponibilizados acerca do sistema BRT, como a série histórica de passageiros transportados e o estudo da frota determinada de passageiros diária. Tais parâmetros foram aplicados ao método de construção do fluxo de caixa utilizado para avaliar os contratos de concessão de serviços de transporte público de ônibus e BRT do Rio de Janeiro, chegando, por fim, na estrutura final utilizada neste estudo.

Os resultados do estudo indicam que é possível obter um ganho de valor no projeto do corredor BRT TransOeste por meio da readequação do nível de serviço do corredor atual, para que ele possa comportar um número maior de passageiros e diminuir os gargalos percebidos atualmente. A avaliação do corredor BRT TransOeste pelo método das Opções Reais sugeriu que a incorporação das estratégias interativas de flexibilidade gerencial relativas às opções de expansão e adiamento da expansão da demanda de pico acarretou um aumento de 30,63\% do valor do projeto original sem estas opções. Assim, o valor esperado do projeto original passou de $\mathrm{R} \$ 193,36$ milhões para $\mathrm{R} \$ 252,89$ milhões, e o valor da opção de expansão da capacidade de passageiros do corredor foi de $\mathrm{R} \$ 59,23$ milhões. 
A análise do sumário de probabilidades de expansão da demanda de pico do corredor BRT TransOeste indicou que o melhor momento para se realizar a opção de expansão ocorre nos anos 6 e 7, sendo que o ano 7 é o período no qual a opção de expansão possui a maior probabilidade de ser exercida.

A análise de sensibilidade mostrou que o valor esperado do projeto de expansão do corredor BRT TransOeste não varia muito em função da variação da variável de incerteza da demanda de pico, visto que uma variação de $2 \%$ da taxa de volatilidade resulta em uma variação de aproximadamente $R \$ 4$ milhões do valor esperado do projeto expandido, ou aproximadamente $1,8 \%$.

Apesar da evidência apresentada neste estudo de que o aumento da capacidade de passageiros transportados gera um aumento no valor esperado do projeto, a conjuntura atual do sistema BRT do Rio de Janeiro impossibilita a concretização desta decisão. Para que esta opção se torne viável do ponto de vista do concessionário, torna-se imprescindível a superação dos desafios relatados no Relatório de Intervenção do BRT, e neste sentido, torna-se imperiosa a participação do poder público no monitoramento do serviço prestado, no auxílio para o saneamento destes problemas.

Uma das ações necessárias para viabilizar tanto a melhora do desempenho operacional como a expansão da capacidade do modo de transporte BRT da cidade do Rio de Janeiro, segundo o relatório de intervenção, é a reformulação da modalidade de concessão do sistema como um todo. Os resultados deste estudo mostram que a participação do poder concedente na gestão conjunta do sistema BRT e a adoção de estratégias para a mitigação de riscos do sistema aumentam o valor esperado do projeto, tornam mais factível a expansão da capacidade operacional do sistema e podem contribuir com o aumento do interesse do setor privado pelo projeto.

A análise do corredor BRT TransOeste como uma concessão separada dos demais corredores se mostrou conveniente neste estudo por ser o trecho no qual se concentram os maiores desafios do sistema BRT do Rio de Janeiro e por apresentar o cenário mais crítico de saturação operacional. Foi avaliada a possibilidade de o poder concedente reduzir os riscos do projeto de expansão do corredor por meio de uma participação conjunta com a concessionária no processo de aquisição dos ativos necessários para expandir o nível máximo de passageiros do sistema e também pela cobertura de uma fração da receita tarifária perdida por conta do índice de evasão de passageiros.

Os resultados mostraram que o aumento da proporção de gastos de capital do poder concedente para adquirir os ativos para expandir a capacidade 
operacional do corredor BRT TransOeste aumentaram o valor esperado do projeto em $\mathrm{R} \$ 20$ milhões e aumentaram a probabilidade de exercício da opção de expansão da capacidade do corredor nos anos 4, 6 e 7. A cobertura de $25 \%$ do total gastos de capital pelo poder concedente gerou um aumento de $34 \%$ do valor da opção de expansão . A cobertura de $1 \%$ da receita tarifária perdida ocasionada pelo índice de evasão de passageiros pelo poder concedente resultou em um incremento de $\mathrm{R} \$ 12$ milhões do valor esperado do projeto expandido, aumentando em $20 \%$ o valor da opção de expansão do corredor.

Desde a sua inauguração no ano de 2012, o modal de transporte BRT da cidade do Rio de Janeiro se mostrou ser um sistema com grande potencial para contribuir com o aumento da integração entre as diferentes regiões da cidade do Rio de Janeiro e na melhora da mobilidade urbana. No entanto, para que isto ocorra, é necessário que o desempenho operacional do sistema ocorra de maneira eficiente, com a disponibilização adequada da frota de veículos necessária para o nível de demanda de passageiros requerido e operando nos intervalos de tempo adequados. Além disso, mostra-se tanto necessária como indispensável a participação e a contribuição do poder público junto ao concessionário designado para gerir o sistema.

A metodologia proposta neste estudo teve como objetivo unir os pressupostos teóricos da abordagem das Opções Reais ao processo de avaliação de grandes projetos de infraestrutura de mobilidade urbana, de modo que se possibilite incorporar de forma eficaz elementos de incerteza e flexibilidade presentes nestes projetos e mensurar o grau de mitigação do risco a que projetos desta natureza estão sujeitos. 


\section{Referências bibliográficas}

BABALIK-SUTCLIFFE, E., \& CENGIZ, E. C. (2015). Bus Rapid Transit System in Istanbul: A Success Story or Flawed Planning Decision? Transport Reviews, 35(6), 792-813. Disponível em:<https://doi.org/10.1080/ 01441647.2015. 1059381>.

BLACK, F., \& SCHOLES, M. (1973). The pricing of options and corporate liabilities. Journal of Political Economy, 81(3), 637-654.

BOWE, M., \& LEE, D. L. (2004). Project evaluation in the presence of multiple embedded real options: Evidence from the Taiwan High-Speed Rail Project. Journal of Asian Economics, 15(1), 71-98. Disponível em: <https://doi.org/ 10.1016/j.asieco.2003.12.001>.

BRANDÃO, L. E. T., BASTIAN-PINTO, C., GOMES, L. L., \& LABES, M. (2012). Government Supports in Public - Private Partnership Contracts : Metro Line 4 of the São Paulo Subway System. Journal of Infrastructure Systems, 18(September), 218-225. Disponível em: <https://doi.org/10.1061/(ASCE) IS. 1943-555X.0000095>.

\& SARAIVA, E. (2008). The option value of government guarantees in infrastructure projects. Construction Management and Economics, 26(11), 1171-1180. Disponível em: <https://doi.org/10.1080/ $01446190802428051>$.

BRASIL. (1995). Lei $\mathrm{n}^{\circ} 8.987$ de 13 de fevereiro de 1995. Diário Oficial Da República Federativa Do Brasil. Brasília, DF. Disponível em: <http://www. planalto.gov.br/ccivil_03/ LEIS/L8987compilada.htm>. Acesso em $11 \mathrm{de}$ outubro de 2019.

CEDER, A. (1984). Bus Frequency Determination. Transportation Research Part A: Policy and Practice, 18(516), 439-453.

CHEAH, C. Y. J., \& LIU, J. (2006). Valuing governmental support in infrastructure projects as real options using Monte Carlo simulation. Construction Management and Economics, 24(5), 545-554. Disponível em: <https://doi.org/10.1080/01446 190500435572>.

CHEN, H., \& QIN, R. (2010). A real options approach of managing public-private partnerships projects under high uncertainty . IIE Annual Conference and Expo 2010 Proceedings. Disponível em:<http://www.scopus.com/inward/ record.url?eid=2-s2.0-4900993228\&partnerID=40\&md5=2bacfff4a9ff1c5d 05ecf9ccf6411f2e>.

COX, J. C., ROSS, S. A., \& RUBINSTEIN, M. (1979). Option Pricing : A Simplified Approach. Journal of Financial Economics, 7(3), 229-263. Disponível em: <https://doi.org/10. 1016/0304-405X(79)90015-1>.

DIAS, M. A. G. (2014). Análise de Investimentos com Opções Reais. Teoria e Prática com Aplicações em Petróleo e Outros Setores. Conceitos Básicos - Volume 1 (1st ed.). Interciência.DIXIT, A. K., \& PINDYCK, R. S. (1994). Investment under Uncertainty. Princetion, New Jersey: Princeton University Press. 
FREITAS, A. S. DE, \& BRANDÃO, L. E. T. (2009). Avaliação de projetos de ELearning através da metodologia de Opções Reais. Journal of Chemical Information and Modeling, 64(15-3), 679-701. Disponível em: <https://doi.org/ 10.1017/ CBO9781107415 324.004>.

HENSHER, D. A., \& GOLOB, T. F. (2008). Bus rapid transit systems: A comparative assessment. Transportation, 35(4), 501-518. Disponível em: <https://doi.org/ 10.1007/s11116 -008-9163-y>.

HIDALGO, D., LLERAS, G., \& HERNÁNDEZ, E. (2013). Methodology for calculating passenger capacity in bus rapid transit systems: Application to the TransMilenio system in Bogotá, Colombia. Research in Transportation Economics, 39(1), 139-142. Disponível em: <https://doi.org/10.1016/j.retrec. 2012.06.006>.

HSU, L. R. (2012). Cost Estimating Model for Mode Choice between Light Rail and Bus Rapid Transit Systems. Journal of Transportation Engineering, 139(1), 20-29. Disponível em: <https://doi.org/10.1061/(asce)te.1943-5436. 0000466>.

KASSENS-NOOR, E., GAFFNEY, C., MESSINA, J., \& PHILLIPS, E. (2018). Olympic Transport Legacies: Rio de Janeiro's Bus Rapid Transit System. Journal of Planning Education and Research, 38(1), 13-24. Disponível em: <https://doi.org/ 10.1177/0739456X16683228>.

LAW, S. M., MACKAY, A. E., \& NOLAN, J. F. (2004). Applying a Real-Options Methodology. Public Works Management \& Policy, 9(2), 145-153. Disponível em: <https://doi.org/10.1177/1087724X04268697>.

LI, Z., GUO, Q., LAM, W. H. K., \& WONG, S. C. (2015). Transit technology investment and selection under urban population volatility: A real option perspective. Transportation Research Part B, 78, 318-340. Disponível em: <https://doi.org/ 10.1016/j.trb.2015.05.006>.

LOGIT. (2014). PLAMUS - Plano de Mobilidade Urbana Sustentável da Grande Florianópolis: Identificação e Estimativa de Potenciais Benefícios. Florianópilis - Santa Catarina. Disponível em: < http://www.spg.sc.gov.br/suderf-downloads>. . (2011). Estudos de Demanda, Funcional , Operacional e de Viabilidade BRT TransOeste. Disponível em: <http://www.rioonibus.com/wpcontent/uploads/ 2018/08/2-Estudo-de-viabilidade-do-BRTTransoeste.pdf>.

MA, G., DU, Q., \& WANG, K. (2018). A concession period and price determination model for PPP projects: Based on real options and risk allocation. Sustainability (Switzerland), 10(3). Disponível em: <https://doi.org/10.3390/ su10030706>.

MARQUES, R. C., \& CRUZ, C. O. (2015). Real Options in Infrastructure : Revisiting the Literature. Jornal of Infrastructure Systems, 21(1), 1-10. Disponível em: <https://doi.org/10.1061/(ASCE)IS.1943-555X.0000188>.

MINISTÉRIO DAS CIDADES. (2008). Manual de BRT: Bus Rapid Transit. Disponível em: <http://www.cidades.gov.br/Index.Php/Publicacoes.Html>.

NELSON, A. C., APPLEYARD, B., KANNAN, S., EWING, R., MILLER, M., \& ESKIC, D. (2013). Bus rapid transit and economic development: Case study of the Eugene-Springfield BRT system. Journal of Public Transportation, 16(3), 41-57. Disponível em: <https://doi.org/10.5038/2375-0901.16.3.3>. 
PIMENTEL, P. M., AZEVEDO-PEREIRA, J., \& COUTO, G. (2008). High Speed Rail Transport Valuation. 14/2008. Working paper.

PUYANA, Á. M. H., RODRÍGUEZ, L. D. G., \& FONSECA, M. F. G. (2017). ¿Por qué TransMilenio en Bogotá está en crisis? Revista Ciudades, Estados y Política, 4(3), 103-118.

PREFEITURA MUNICIPAL DO RIO DE JANEIRO. (2019). Relatório de Intervenção no BRT. Rio de Janeiro - RJ. Relatório técnico. Disponível em: $<$ https://diariodotransporte.com.br/wp-content/uploads/2019/07/RELAT\% C3\%93RIO-INTERVEN\%C3\%87\%C3\%830-BRT-RIO.pdf>.

SECRETARIA MUNICIPAL DE TRANSPORTES DA CIDADE DO RIO DE JANEIRO (2018). P42 - Relatório do Fluxo de Caixa dos contratos de concessão do Sistema de Transporte de Passageiros de ônibus. (2018). Rio de Janeiro/RJ. Relatório técnico.

SILVA, A. DE J. F. (2018). 80p. Dissertação de Mestrado. Análise do projeto VLT Carioca via opções reais avaliando o retorno para o vencedor da licitação e os impactos dos incentivos governamentais.

SITRUK, J. (2010). Real options and incentives in a PPP railway project.

TRIGEORGIS, L. (1996). Real Options: Managerial Flexibility and Strategy in Resource Allocation. Cambridge, Massachussets: MIT Press.

WILLIAM, R., ALEXANDRE, C., \& BALASSIANO, R. (2012). BRT no Rio de Janeiro: Implicações para Mobilidade Urbana. In X Rio de Transportes (pp. 1-12). Rio de Janeiro.

WIRASINGHE, S. C., KATTAN, L., RAHMAN, M. M., HUBBELL, J., THILAKARATNE, R., \& ANOWAR, S. (2013). Bus rapid transit - a review. International Journal of Urban Sciences, 17(1), 1-31. Disponível em : <https:// doi.org/10.1080/12265934. 2013.777514>. 


\section{Anexos}

\subsection{Fluxo de caixa do projeto pelo método do FCD}

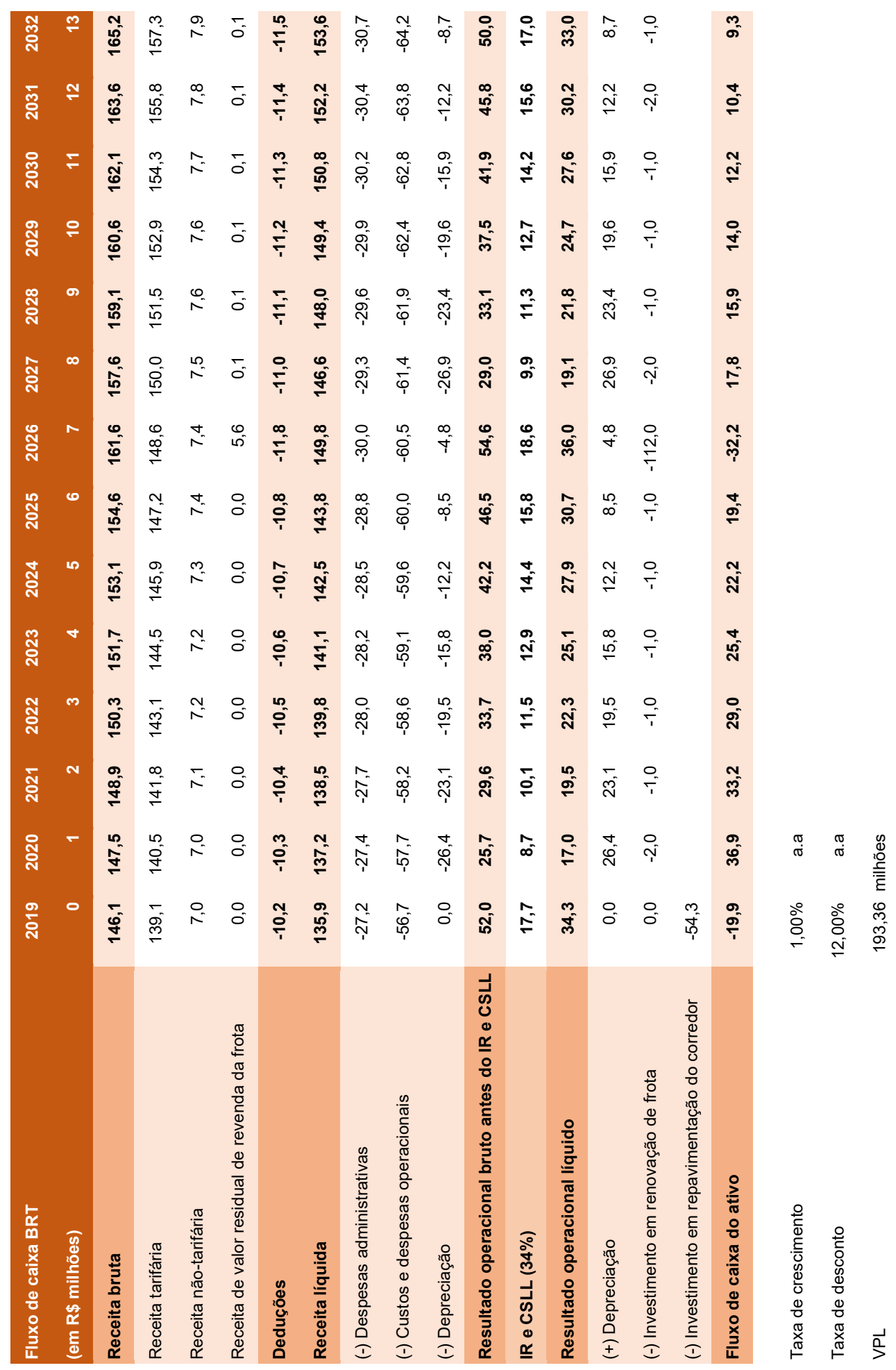




\subsection{Fluxo de caixa do projeto pela abordagem neutra ao risco}

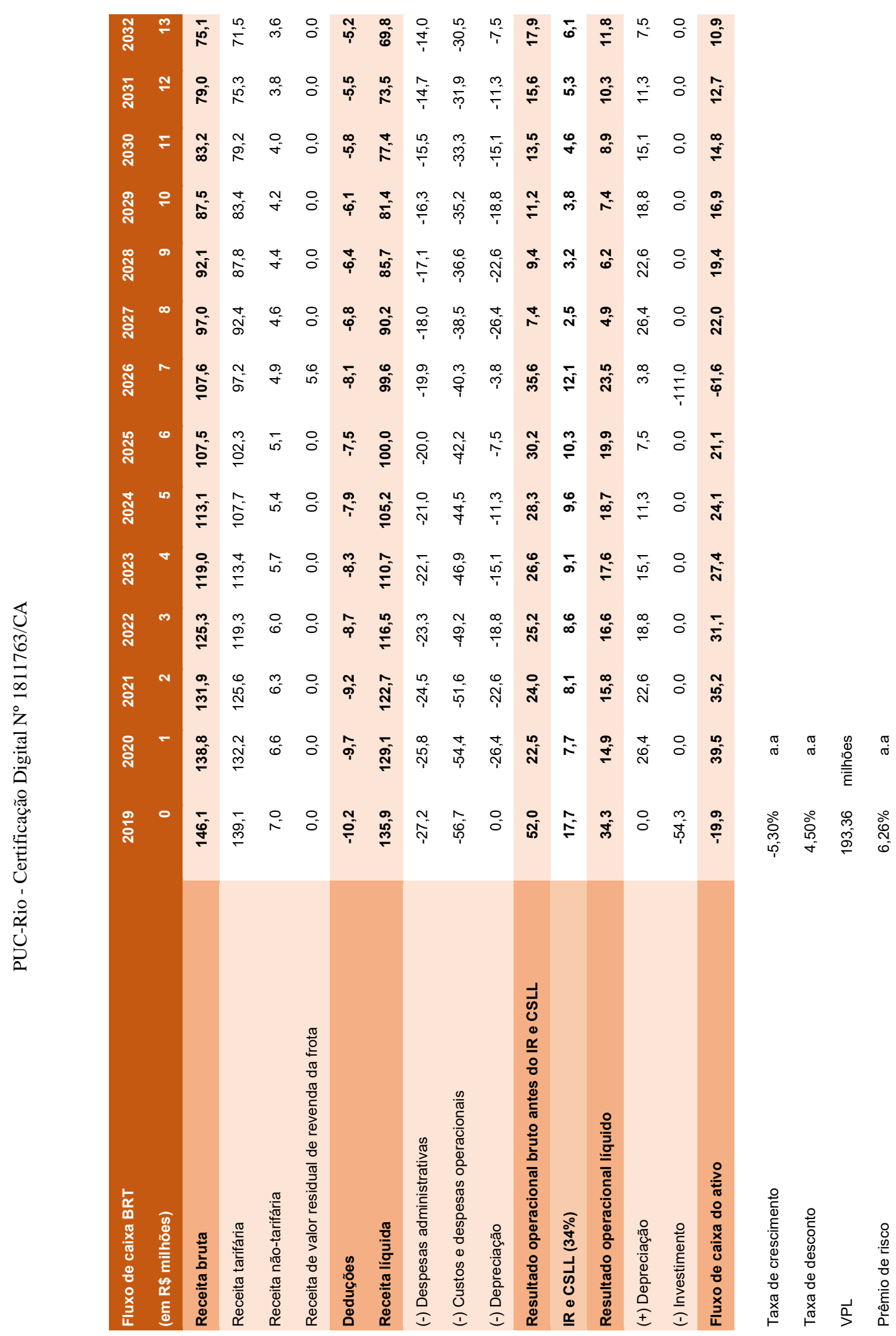


9.3.Demanda diária média de passageiros transportados por estação

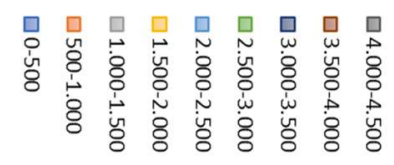

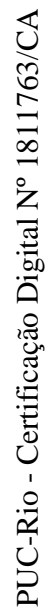

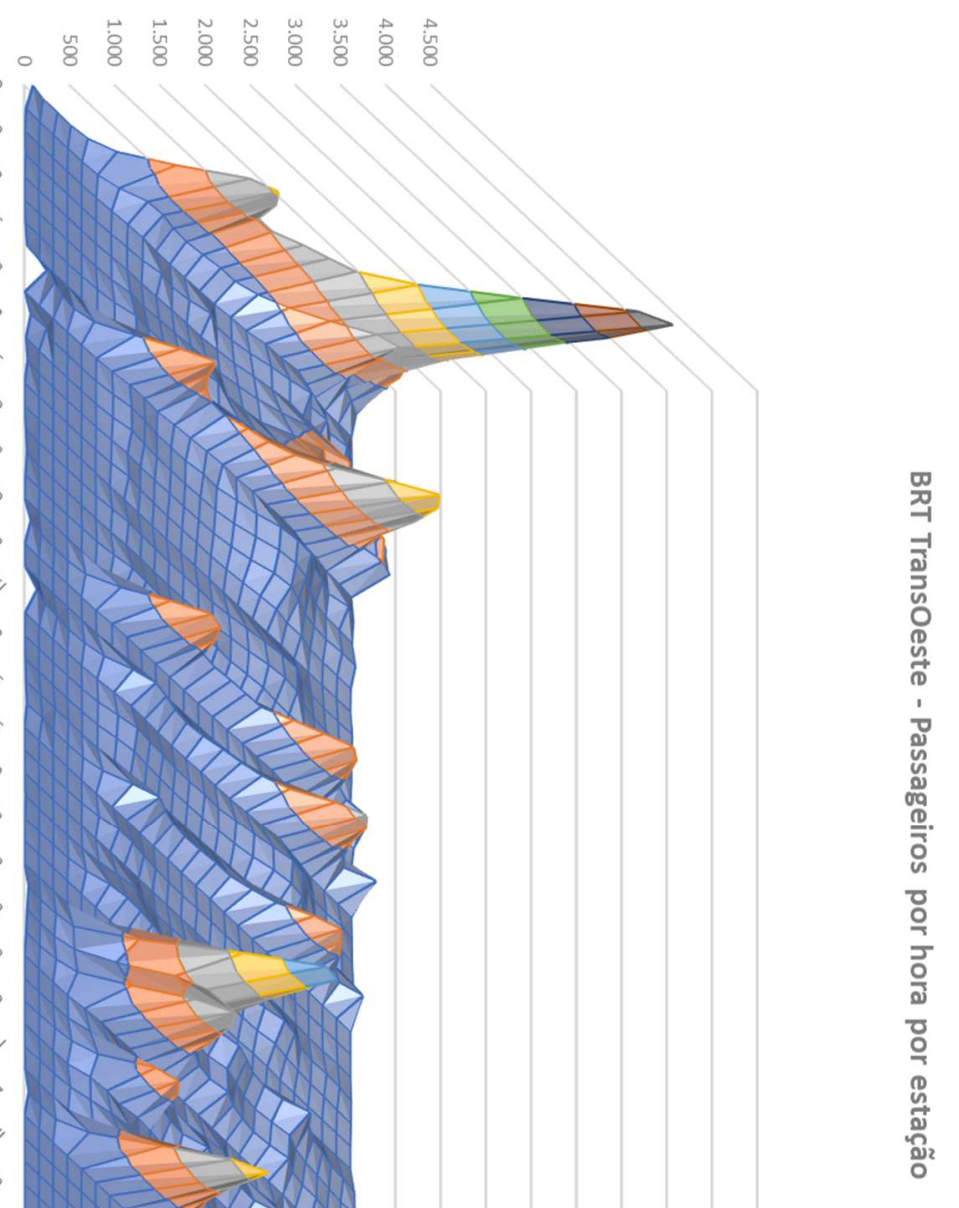




\subsection{Linhas de ônibus por estação do corredor BRT TransOeste}

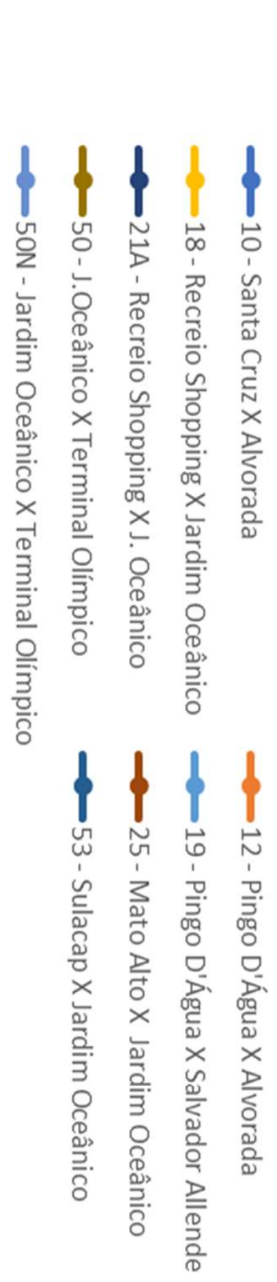

01 - Jardim Oœânico

02 - Bosque de Marapendi

03 - Paulo Malta Rezende

04 - Afrânio Costa

05 - Riviera

06 - Ricardo Marinho

07 - Parque das Rosas

08 - Barra Shopping

09 - Terminal Alvorada

10 - Bosque da Barra

11 - Novo Leblon

12 - Américas Park

13 - Santa Mônica Jardins

14 - Riomar

15 - Golfe Olímpico

16 - Interlagos

17 - Pedra de Itaúna

18 - Pontões/ Barrasul

19 - Terminal Recreio

20 - Salvador Allende

21 - Gel son Fonseca

22 - Guignard

23 - Gláucio Gil

24 - Benvindo de Novaes

25 - Nova Barra

26 - Gilka Machado

27 - Guiomar Novais

28 - Recreio Shopping

29 - Recanto das Garças

30 - Notre Dame

31 - Dom Bosco

32 - Pontal

33 - Ilha de Guaratiba

34 - Cetex

35 - Embrapa

36 - Mato Alto

37 - Magarça

38 - Pingo D'Água

39 - Vendas de Varanda

40 - Santa Veridiana

41 - Curral Fal so

42 - Cajueiros

43 - Gastão Rangel

44 - General Olimpio

45 - Terminal Santa Cruz

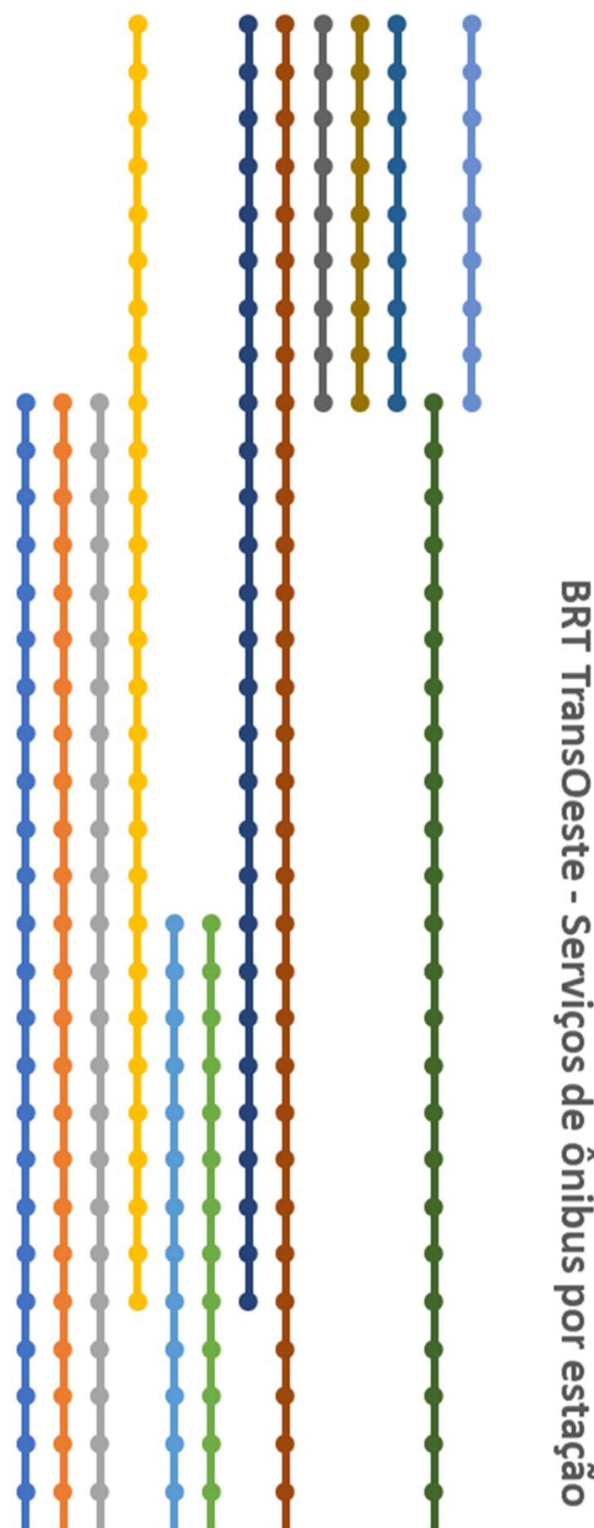

